\title{
Evaluation of the global aerosol microphysical ModelE2-TOMAS model against satellite and ground-based observations
}

\author{
Y. H. Lee ${ }^{1}$, P. J. Adams ${ }^{2}$, and D. T. Shindell ${ }^{1}$ \\ ${ }^{1}$ Earth and Ocean Sciences, Nicholas School of the Environment, Duke University, Durham, NC 27708, USA \\ ${ }^{2}$ Department of Civil and Environmental Engineering and Department of Engineering Public Policy, \\ Carnegie Mellon University, Pittsburgh, PA, USA \\ Correspondence to: Y. H. Lee (yunha.lee.00@gmail.com)
}

Received: 11 July 2014 - Published in Geosci. Model Dev. Discuss.: 3 September 2014

Revised: 16 January 2015 - Accepted: 10 February 2015 - Published: 20 March 2015

\begin{abstract}
The TwO-Moment Aerosol Sectional (TOMAS) microphysics model has been integrated into the state-ofthe-art general circulation model, GISS ModelE2. This paper provides a detailed description of the ModelE2-TOMAS model and evaluates the model against various observations including aerosol precursor gas concentrations, aerosol mass and number concentrations, and aerosol optical depths. Additionally, global budgets in ModelE2-TOMAS are compared with those of other global aerosol models, and the ModelE2-TOMAS model is compared to the default aerosol model in ModelE2, which is a one-moment aerosol (OMA) model (i.e. no aerosol microphysics). Overall, the ModelE2TOMAS predictions are within the range of other global aerosol model predictions, and the model has a reasonable agreement (mostly within a factor of 2) with observations of sulfur species and other aerosol components as well as aerosol optical depth. However, ModelE2-TOMAS (as well as ModelE2-OMA) cannot capture the observed vertical distribution of sulfur dioxide over the Pacific Ocean, possibly due to overly strong convective transport and overpredicted precipitation. The ModelE2-TOMAS model simulates observed aerosol number concentrations and cloud condensation nuclei concentrations roughly within a factor of 2 . Anthropogenic aerosol burdens in ModelE2-OMA differ from ModelE2-TOMAS by a few percent to a factor of 2 regionally, mainly due to differences in aerosol processes including deposition, cloud processing, and emission parameterizations. We observed larger differences for naturally emitted aerosols such as sea salt and mineral dust, as those emission rates are quite different due to different upper size cutoff assumptions.
\end{abstract}

\section{Introduction}

Aerosols perturb the energy balance of the Earth-atmosphere system by scattering and absorbing solar and terrestrial radiation, known as the aerosol direct effect, and by modifying cloud properties by acting as cloud condensation nuclei $(\mathrm{CCN})$, known as aerosol indirect effects (e.g. Lohmann and Feichter, 2005; Forster and Ramaswamy, 2007). The recently published IPCC AR5 (Intergovernmental Panel on Climate Change Fifth Assessment Report) refers to these as aerosolradiation interactions and aerosol-cloud interactions, respectively (Boucher et al., 2013). For light-absorbing aerosols such as black carbon and mineral dust, the ambient air can be heated as a result of their direct effect, affecting relative humidity and atmospheric stability, which is known as the semidirect effect. The largest uncertainty in estimating anthropogenic climate forcing is from the aerosol indirect effects (Myhre et al., 2013b). Since it is not easily estimated from observations due to natural variability in cloud properties and the lack of observations of the pre-industrial atmosphere, estimates of aerosol indirect forcing have been mainly based on general circulation models (GCMs). Thus, there have been growing efforts to develop and improve aerosol microphysics models for a more physically based representation of atmospheric aerosol number and CCN concentrations (e.g. Adams and Seinfeld, 2002; Easter et al., 2004; Vignati et al., 2004; Lauer et al., 2005; Liu et al., 2005; Spracklen et al., 2005; Stier et al., 2005; Bauer et al., 2008; Trivitayanurak et al., 2008; Yu and Luo, 2009; Mann et al., 2010; Lee and Adams, 2012). 
Aerosol microphysics models can be broadly categorized into modal and sectional methods, depending on how they represent the aerosol size distribution. In general, modalbased methods use an analytical function (e.g. a lognormal distribution) to represent a subset of the particle population. Sectional methods represent a size distribution by predicting aerosols in several size sections or "bins". Additionally, sectional and modal methods may differ from each other in numerous ways, including the number of moments of the size distributions that are tracked in each section or mode.

Sectional methods can be divided into single-moment sectional methods that typically track either aerosol number or mass in each bin and two-moment sectional methods that explicitly track both aerosol number (i.e. Oth moment) and mass (i.e. first mass moment or third radial moment) in each size section. Unlike single-moment sectional approaches, twomoment sectional methods can conserve both number and mass very accurately (Tzivion et al., 1987, 2001; Feingold et al., 1988; Harrington and Kreidenweis, 1998; Adams and Seinfeld, 2002; Jung et al., 2006), but have a high computational burden. The modal approaches are generally more computationally efficient, but may not represent abrupt transitions in a size distribution well, which can occur during cloud processing (Zhang et al., 1999).

The TOMAS aerosol microphysics model (Adams and Seinfeld, 2002; Tzivion et al., 1987, 1989) has been developed to study tropospheric aerosol microphysics and predict cloud condensation nuclei $(\mathrm{CCN})$ concentrations. The TOMAS model has been previously implemented into the climate model of Goddard Institute for Space Studies General Circulation Model II-prime (GISS GCM II-prime), referred to as "GISS-TOMAS" (Lee and Adams, 2010). It has also been incorporated into GEOS-CHEM (Trivitayanurak et al., 2008), the PMCAMx-UF regional model (Jung et al., 2010), and the Large-Eddy Simulation model (Stevens et al., 2012; Singh et al., 2014). The GISS GCM II-prime has horizontal grid dimensions of $4^{\circ}$ latitude and $5^{\circ}$ longitude, with nine vertical sigma layers between the surface and the $10 \mathrm{hPa}$ level (Hansen et al., 1983). Modules for each of the major aerosol species have been developed for the GISS GCM II-prime, and the GISS-TOMAS model has been evaluated with ground-level measurements such as number and mass concentrations, deposition fluxes, and remote sensing observations (Adams and Seinfeld, 2002; Pierce and Adams, 2006; Pierce et al., 2007; Lee et al., 2009; Lee and Adams, 2010). Despite the accuracy in predicting aerosol microphysical processes in TOMAS, the original version of TOMAS has a heavy computational burden. Lee and Adams (2012) developed less computationally expensive configurations of the TOMAS model (fast TOMAS), which are 2-3 times faster than the original TOMAS model, with only a few percent increases in microphysical errors. However, a remaining weakness for the GISS-TOMAS model is the outdated host model, the GISS GCM II-prime.
Here, we incorporate the TOMAS model into the new version of GISS GCM (i.e. ModelE2), referred to as "ModelE2TOMAS". ModelE2 now has three different aerosol models available: TOMAS, the One-Moment Aerosol model (hereafter, referred to as OMA) (e.g. Koch et al., 2006) that has no microphysics, and the modal-based aerosol microphysics model, MATRIX (Multiconfiguration Aerosol TRacker of mIXing state) (Bauer et al., 2008). The combination of several aerosol models allows ModelE2 to explore the uncertainties in predicting aerosol characteristics and their climate effects that are associated with aerosol modelling (e.g. different numerical approaches) in the same host model. We also note that it was important to implement the TOMAS aerosol model into the ModelE2 host model because uncertainties in the estimates of aerosol forcing come not only from aerosol modelling itself, but also other parts of the host GCM (e.g. cloud physics, planetary boundary layer, and advection).

ModelE2-TOMAS has been used in several recent studies under the Atmospheric Chemistry and Climate Model Intercomparison Project (ACCMIP), which aims to understand composition changes and the associated radiative forcing between 1850 and 2100 (Bowman et al., 2013; Lamarque et al., 2013a, b; Lee et al., 2013a; Nabat et al., 2013; Naik et al., 2013; Shindell et al., 2013; Stevenson et al., 2013; Young et al., 2013). Here we give a detailed description of ModelE2-TOMAS and evaluate against ModelE2OMA (e.g. Schmidt et al., 2014) and observations of aerosol mass and number as well as aerosol optical depth. Sections 2 and 3 provide descriptions of ModelE2-OMA and ModelE2TOMAS, respectively. Section 4 explains the emissions and design of the simulations. Section 5 presents global budgets of the simulated aerosols and the evaluation of the ModelE2TOMAS and ModelE2-OMA against observations of aerosol mass concentrations and aerosol optical depth and the evaluation of the TOMAS number predictions against observations. Conclusions follow in Sect. 6. We note that aerosol direct and indirect forcings using ModelE2-TOMAS will be discussed in a separate paper.

\section{GISS GCM ModelE2}

In this section, we briefly describe ModelE2 (Schmidt et al., 2014), the GISS climate model used to perform Coupled Model Intercomparison Phase 5 (CMIP5; Taylor et al., 2012). The model physics are mostly similar to GISS ModelE (CMIP3 version: Schmidt et al., 2006). The model has $2^{\circ}$ latitude by $2.5^{\circ}$ longitude resolution, with 40 vertical hybrid sigma layers from the surface to $0.1 \mathrm{hPa}(80 \mathrm{~km})$. Tracers, heat, and humidity are advected using the highly nondiffusive Quadratic Upstream Scheme (Prather, 1986). The radiation scheme accounts for size-dependent scattering properties of clouds and aerosols based on Mie scattering (Hansen et al., 1983) and non-spherical light scattering of cirrus and dust particles based on T-matrix theory (Mishchenko et al., 
1996). It also includes the impact of water uptake by hygroscopic species on their radiative properties. In the model, clouds are distinguished into convective and large-scale stratiform clouds. The cloud parameterizations are similar to Del Genio and Yao (1993) and Del Genio et al. (1996), but have been improved in several respects (see details in Schmidt et al., 2006, 2014). The physics time step is $30 \mathrm{~min}$, and the radiation is calculated every $2.5 \mathrm{~h}$.

\subsection{ModelE2-OMA description}

ModelE2 includes a default aerosol module, OMA (OneMoment Aerosol), which has no microphysics. ModelE2OMA has sulfate (Koch et al., 2006, 2007, 2011), carbonaceous aerosols (Koch et al., 2007), secondary organic aerosols (Tsigaridis and Kanakidou, 2007), sea salt (Koch et al., 2006; Tsigaridis et al., 2013), dust (Miller et al., 2006), and nitrate (Bauer et al., 2007). Along with sulfate, the model also predicts sulfur dioxide, dimethyl sulfide (DMS) and methanesulfonic acid (MSA) (Koch et al., 2006). The secondary organic aerosol formation is computed using a two-product model with isoprene, monoterpenes, and sesquiterpenes as SOA precursors (described in Tsigaridis and Kanakidou, 2007). Sea-salt particles have two size classes with a fine mode ( 0.1 to $1 \mu \mathrm{m}$ in dry radii) and a coarse mode ( 1 to $4 \mu \mathrm{m}$ in dry radii). Dust particles have four size classes with radii between 0.1 and $1 \mu \mathrm{m}$ (clay), 1 and $2 \mu \mathrm{m}$ (silt1), 2 and $4 \mu \mathrm{m}$ (silt2), and 4 and $8 \mu \mathrm{m}$ (silt3). The model accounts for heterogeneous chemistry on mineral dust particle surfaces to form nitrate and sulfate (Bauer and Koch, 2005).

In ModelE2, the surface boundary conditions are defined using dry deposition and interactive surface sources (Koch et al., 2006). The dry deposition scheme is tightly coupled to the model's boundary layer scheme and is based on a resistance-in-series scheme derived from the Harvard GISSCTM, which is applied between the surface layer $(10 \mathrm{~m})$ and the ground (Koch et al., 2006). Wet deposition is determined by several processes including rainout within clouds, washout below precipitating regions, scavenging within and below cloud updrafts, evaporation of falling precipitation, transport along with convective plumes, and detrainment and evaporation from convective plumes (Koch et al., 2006; Shindell et al., 2006). ModelE2 includes a dissolved species budget scheme for stratiform clouds, which has an impact on sulfate formation via aqueous oxidation, since some sulfate formed in clouds undergoes wet scavenging instead of being added back to the sulfate in air (Koch et al., 2006).

Tropospheric/stratospheric chemistry in ModelE2 includes 156 chemical reactions among 51 gas species (Shindell et al., 2013). In ModelE2, chemistry and aerosols are fully interactive, so that the oxidation fields used for sulfate formation are from the chemistry model (not prescribed) and the photolysis rates are affected by light attenuation by aerosols (Shindell et al., 2013). Photolysis rates are com- puted using the Fast-J2 scheme (Bian and Prather, 2002). Aerosol indirect effects are based on an empirical parameterization that computes cloud droplet number concentrations as a function of aerosol mass (Menon et al., 2002, 2008).

\section{ModelE2-TOMAS description}

The TOMAS aerosol microphysics model uses a sectional approach that represents the aerosol size distribution by predicting the amount of aerosol in several size categories or "bins". TOMAS tracks two moments of the aerosol size distribution in each size bin: total aerosol number (i.e. 0th moment) and mass (i.e. first mass moment). Total mass is decomposed into several aerosol species, allowing prediction of the size-resolved aerosol composition. In total, ten quantities are tracked for each size bin: sulfate mass, sea-salt mass, mass of pure (hydrophobic) elemental carbon (EC), mass of mixed (aged) EC, mass of hydrophobic organic matter (OM), mass of hydrophilic OM, mass of mineral dust, mass of ammonium, mass of water and the number of aerosol particles in that bin. In TOMAS, all ammonia becomes ammonium aerosol until sulfate is neutralized to form ammonium sulfate; the excess ammonia after neutralization remains as free gas-phase ammonia. The ammonium aerosol is partitioned into each size bin in proportion to the sulfate mass. However, ammonium is not size-resolved (i.e. bulk tracer) for the purpose of model processes outside of TOMAS such as advection and deposition. In addition, the model tracks four bulk gas-phase species: sulfur dioxide $\left(\mathrm{SO}_{2}\right)$, dimethylsulfide (DMS), sulfuric acid $\left(\mathrm{H}_{2} \mathrm{SO}_{4}\right)$, and a lumped gasphase tracer that represents oxidized organic vapours forming secondary organic aerosol (SOA). The gas-phase $\mathrm{H}_{2} \mathrm{SO}_{4}$ is assumed to be in pseudo-steady state equilibrium between its chemical production and condensational/nucleation losses (Pierce and Adams, 2009a). Water uptake by sulfate and sea salt is based on a polynomial fit based on ISORROPIA, a thermodynamic equilibrium model for inorganic aerosols (Nenes et al., 1998). For water uptake by hydrophilic OM, it is based on the observations of Dick et al. (2000). The size section boundary is defined by dry particle mass, such that addition or removal of aerosol water mass does not move particles between sections. In general, TOMAS treats all aerosols as internally mixed during microphysics such as calculating condensation and coagulation rates. However, a portion of EC is treated as externally mixed for the purpose of wet deposition. A detailed description of the TOMAS microphysics scheme can be found in Adams and Seinfeld (2002), Lee and Adams (2012), and Lee et al. (2013b).

Several alternative nucleation schemes are available in TOMAS, including binary nucleation (Vehkamaki et al., 2002), ternary nucleation (Napari et al., 2002), ion-induced nucleation (Modgil et al., 2005), and activation nucleation with an $A$ factor of $2 \times 10^{-6} \mathrm{~s}^{-1}$ (Sihto et al., 2006) for the boundary layer ( $\sim$ up to $900 \mathrm{hPa}$ ). For the simulations used 
in this paper, only binary nucleation is used. The boundarylayer nucleation is off in all simulations because it tends to overpredict aerosol number concentrations in our model. Also we do not show any run with the ternary nucleation (Napari et al., 2002) because it overpredicts aerosol number concentration severely (not shown).

With fast TOMAS models, the TOMAS microphysics module became more flexible in terms of varying particle size resolution, i.e. the number of size bins (Lee and Adams, 2012). For the size range of $10 \mathrm{~nm}$ to $10 \mu \mathrm{m}$, the original TOMAS uses 30 bins (size boundary is defined with mass doubling), and the fast TOMAS uses 15 bins or 12 bins (the size boundary is defined with mass quadrupling). As discussed in Lee and Adams (2012), the fast TOMAS reduces the computational burden by $2-3$ times while generally predicting $\mathrm{CCN}$ concentrations within a few percent of the original TOMAS. The lower size cutoff in TOMAS can also vary from 10 to $3 \mathrm{~nm}$ or from 10 to $1 \mathrm{~nm}$ (Lee et al., 2013b). Among several possible configurations, ModelE2-TOMAS currently uses either 12 bins covering $10 \mathrm{~nm}$ to $10 \mu \mathrm{m}$ or 15 bins covering $3 \mathrm{~nm}$ to $10 \mu \mathrm{m}$, which is the most computationally efficient version of TOMAS for the given size range. In this paper, we used TOMAS with 15 bins covering $3 \mathrm{~nm}$ to $10 \mu \mathrm{m}$ (TOMAS15; see Table S1 in the Supplement): 3 bins cover from 3 to $10 \mathrm{~nm}, 10$ bins from $10 \mathrm{~nm}$ to $1 \mu \mathrm{m}$ and the last two bins from 1 to $10 \mu \mathrm{m}$. The TOMAS15 version has become the default model configuration for ModelE2TOMAS, so we will refer to it as ModelE2-TOMAS throughout this paper. More configurations will be available in the near future. The wet deposition scheme in ModelE2-TOMAS is identical to the one used in ModelE2-OMA except for the following. First, ModelE2-TOMAS adds sulfate mass produced in the aqueous phase directly to the bin-resolved sulfate mass in ambient air rather than maintaining a separate tracer for dissolved sulfate. Compared to ModelE2-OMA, this is a simplification because the sulfate formed in the aqueous phase will be only released as interstitial aerosol when the cloud water evaporates. It is adopted here for simplicity, but will be improved in the future. The other difference is that the wet/dry deposition in ModelE2-TOMAS accounts for particle size dependence. For in-cloud scavenging, modified Köhler theory is used to obtain the critical supersaturation for activation of each size section and to determine which particles activate and are subject to in-cloud (nucleation) scavenging (Pierce et al., 2007). To determine activation, we assume kappa values of 0.7 for sulfate, 1.3 for sea salt, and 0.15 for hydrophilic OM. The fraction of activated aerosols removed by wet deposition is proportional to the fraction of cloud water that precipitates, which is computed in each model layer. Wet deposition accounts for re-evaporation of precipitation. For in-cloud scavenging, the large-scale and convective clouds in the model are assumed to have a supersaturation of $0.2 \%$; unlike GISS-TOMAS that used a supersaturation of $1.0 \%$ for convective clouds, a supersaturation of $0.2 \%$ is assumed in ModelE2-TOMAS in order to capture the observed Hoppel gap $(\sim 100 \mathrm{~nm})$ in the marine boundary layer. Note that the activation described here to determine in-cloud scavenging is not used for computing cloud droplet number concentrations (see below). For below-cloud scavenging, a first-order removal scheme implemented for bulk aerosols by Koch et al. (1999) is modified for sizeresolved aerosols (Adams and Seinfeld, 2002). Dry deposition is identical to the existing resistance-in-series scheme in ModelE2, but ModelE2-TOMAS considers size-dependent gravitational settling of particles and size-dependent resistance in the quasi-laminar sublayer (Seinfeld and Pandis, 1998; Adams and Seinfeld, 2002).

To compute the cloud microphysics properties as a function of aerosols (i.e. the aerosol-cloud interactions), ModelE2-TOMAS uses a physically based activation parameterization from Nenes and Seinfeld (2003). A critical supersaturation is computed in the parameterization using a model updraft velocity that is computed based on a large-scale vertical velocity and sub-grid velocity.

In ModelE2-TOMAS, Mie theory is used to compute sizeresolved aerosol optical depth (AOD). For each grid cell, particle compositions (including aerosol water) in each individual size bin are used to compute the volume-averaged refractive index and optical properties based on Mie theory. The optical properties are used to compute aerosol optical depth taking into account the aerosol concentration.

ModelE2-TOMAS is coupled to the same gas chemistry model (Shindell et al., 2013) as ModelE2-OMA. So, the oxidation fields used for sulfate formation are from the chemistry model. However, unlike ModelE2-OMA, the photolysis rates are not affected by aerosols.

\section{Description of the simulations}

\subsection{Emissions}

The emissions used in this study are summarized in Table 1. The simulations used year-2000 emissions from the anthropogenic emissions inventory created for CMIP5 (Lamarque et al., 2013b) and climatologically averaged biomass burning emissions from GFED3 for 1997 to 2009 (van der Werf et al., 2010). For $\mathrm{SO}_{2}$, in addition to the anthropogenic emissions, continuous volcanic emissions from GEIA (Global Emissions InitiAtive; Andres and Kasgnoc, 1998) are used but increased by a factor of 1.5 as in the AEROCOM intercomparison emissions in Dentener et al. (2006). Sea-salt emissions are based on Gong (2003), which extends the lower size limit of the Monahan et al. (1986) emission from 0.4 to $0.02 \mu \mathrm{m}$. Dust emissions are based on the source distribution from Ginoux et al. (2001) and are proportional to the third power of the wind speed (at $10 \mathrm{~m}$ in height) above a threshold that is a function of soil moisture. Subgrid-scale variation of the wind speed in a GCM grid box, which is created by boundary-layer turbulence and dry/wet convection, 
Table 1. Aerosol and precursor gas emissions used in ModelE2-TOMAS and ModelE2-OMA and the nucleation scheme used in the ModelE2-TOMAS simulations.

\begin{tabular}{|c|c|c|}
\hline Emission/process & TOMAS model & Bulk model \\
\hline Anthropogenic emissions & $\begin{array}{l}\text { CMIP5 } 2000 \text { emissions (Lamarque et al., } \\
\text { 2013b) }\end{array}$ & $\begin{array}{l}\text { CMIP5 } 2000 \text { emissions (Lamarque et al., } \\
\text { 2013b) }\end{array}$ \\
\hline Biomass burning emissions & $\begin{array}{l}\text { Climatological-average GFED3 emis- } \\
\text { sions from } 1997 \text { to } 2009 \text { (van der Werf et } \\
\text { al., 2010) }\end{array}$ & $\begin{array}{l}\text { Climatological-average GFED3 emis- } \\
\text { sions from } 1997 \text { to } 2009 \text { (van der Werf et } \\
\text { al., 2010) }\end{array}$ \\
\hline Primary sulfate emission assumption & $1.0 \%$ of total sulfur emissions & $2.5 \%$ of total sulfur emissions \\
\hline DMS emission & $\begin{array}{l}\text { Seawater DMS concentrations from Ket- } \\
\text { tle et al. (1999) } \\
\text { Sea-to-air transfer function from Liss and } \\
\text { Merlivat (1986) }\end{array}$ & $\begin{array}{l}\text { Seawater DMS concentrations from Ket- } \\
\text { tle et al. (1999) } \\
\text { Sea-to-air transfer function from Nightin- } \\
\text { gale et al. (2000) }\end{array}$ \\
\hline Sea-salt emission & $\begin{array}{l}\text { Gong et al. (2003); the upper diameter } \\
\text { limit of } 10 \mu \mathrm{m}\end{array}$ & $\begin{array}{l}\text { Gong et al. (2003); the upper diameter } \\
\text { limit of } 8 \mu \mathrm{m}\end{array}$ \\
\hline Dust emission & $\begin{array}{l}\text { See text for the details; the upper size di- } \\
\text { ameter of } 10 \mu \mathrm{m} \text {. }\end{array}$ & $\begin{array}{l}\text { See text for the details; the upper size di- } \\
\text { ameter of } 16 \mu \mathrm{m} \text {. }\end{array}$ \\
\hline Nucleation & $\begin{array}{l}\text { Three nucleation cases } \\
\text { 1. BASE - Binary nucleation } \\
\text { 2. LowNUC - Binary nucleation with } 5 \\
\text { times lower sulfuric acid concentrations } \\
\text { 3. NoNUC - no nucleation }\end{array}$ & N/A \\
\hline
\end{tabular}

is accounted for in the modelled dust emissions (Cakmur et al., 2006; Miller et al., 2006). DMS emissions are based on the seawater DMS concentrations of Kettle et al. (1999). For the sea-to-air transfer function used in the DMS emissions, the ModelE2-TOMAS runs are based on Liss and Merlivat (1986), and the ModelE2-OMA model run is based on Nightingale et al. (2000).

Nightingale et al. (2000) provide a revised parameterization based on observations of the sea-to-air transfer rate scatter between two classical parameterizations (i.e. Liss and Merlivat, 1986; Wanninkhof, 1992), and it has been more favoured in many global DMS models than the two classical parameterizations. However, DMS emissions are quite uncertain. Estimates of the global DMS emissions range from 16 to $54 \mathrm{Tg} \mathrm{Syr}^{-1}$ (Kettle and Andreae, 2000), depending on the choice of DMS sea surface climatology, sea-to-air transfer rate parameterization, and wind speed data. DMS emission rates from ModelE2-TOMAS (16.1 $\mathrm{TgS} \mathrm{yr}^{-1}$; see Table 3) and ModelE2-OMA (28.7 $\mathrm{Tg} \mathrm{Syr}^{-1}$; see Table 3 ) are within this range. The Liss and Merlivat (1986) parameterization is used in ModelE2-TOMAS, because a ModelE2-TOMAS run based on Nightingale et al. (2000) overpredicts the $\mathrm{SO}_{2}$ concentrations over remote oceanic regions, especially in the Southern Hemisphere. Koch et al. (2006) showed that the sea-to-air transfer function from Nightingale et al. (2000) increased annual DMS emissions by roughly a factor of 2 compared to the emission based on Liss and Merlivat (1986). This was desirable in ModelE2-OMA because of the un- derprediction of sulfate in remote oceanic regions in that model, although the model DMS and MSA (oxidized from DMS) tended to be excessive in Southern Hemisphere (SH) oceanic regions, especially near Antarctica. However, despite the higher DMS emissions, it turned out that the sulfate was still underpredicted, because sulfate formed by aqueous oxidation was subject to wet scavenging before releasing to the ambient air as a result of the updated dissolved species budget scheme (Koch et al., 2006).

\subsection{ModelE2-TOMAS run setup}

We performed the simulations nudged with winds from the MERRA (Modern Era Retrospective-analysis for Research and Applications; Rienecker et al., 2011) reanalysis meteorological fields from 2000 to 2003 with 3 years spin-up (i.e. 1997-1999). Primary emissions of particulate sulfate are assumed to be $1 \%$ of total sulfur emissions. Emissions size distributions assumed for ModelE2-TOMAS are summarized in Table 2. Primary sulfate emissions are assumed to have a bi-modal lognormal distribution that assigns $5 \%$ of the primary sulfate emissions as a nucleation mode with a geometric number mean diameter (GMD) of $10 \mathrm{~nm}$ and a geometric standard deviation (GSD) of 1.6 and the rest as an Aitken mode with GMD of $70 \mathrm{~nm}$ and GSD of 2. For fossil fuel and biofuel emissions, the size of primary carbonaceous aerosol emissions are assumed to follow a lognormal size distribution with a GMD of $60 \mathrm{~nm}$ and a GSD of 1.59 for both EC 
Table 2. Emission size distributions assumed in ModelE2-TOMAS. * This is the soil size assumption used in ModelE2-TOMAS, and the dust emission size distribution is additionally influenced by meteorological variables. GMD stands for geometric mean diameter, and GSD for geometric standard deviation.

\begin{tabular}{lll}
\hline Species & Emissions & Size assumptions \\
\hline \multirow{3}{*}{ Sulfate } & All emissions & $\begin{array}{l}\text { Bimodal distribution } \\
\text { GMD }=10 \mathrm{~nm}, \mathrm{GSD}=1.6(5 \% \text { of total mass })\end{array}$ \\
& & GMD $=70 \mathrm{~nm}, \mathrm{GSD}=2.0(95 \%$ of total mass $)$ \\
\hline \multirow{2}{*}{ EC and OC } & $\begin{array}{l}\text { Fossil fuel and biofuel } \\
\text { biomass burning }\end{array}$ & $\mathrm{GMD}=60 \mathrm{~nm}, \mathrm{GSD}=1.59$ \\
& GMD $=150 \mathrm{~nm}, \mathrm{GSD}=1.59$ \\
\hline \multirow{2}{*}{ Dust* } & Clay & GMD $=140 \mathrm{~nm}, \mathrm{GSD}=2.0$ \\
& Silt & GMD $=1.15 \mu \mathrm{m}, \mathrm{GSD}=2.0$ \\
\hline
\end{tabular}

Table 3. Global budgets for DMS and $\mathrm{SO}_{2}$ from the BASE run in ModelE2-TOMAS and ModelE2-OMA. The ModelE2-TOMAS values are presented before slashes and the ModelE2-OMA values are after slashes. Values in parentheses are ranges from other global models including Wang et al. (2011), Liu et al. (2005), and those listed in Liu et al. (2005).

\begin{tabular}{|c|c|c|}
\hline & DMS & $\mathrm{SO}_{2}$ \\
\hline Burden $(\operatorname{Tg} S)$ & $\begin{array}{c}0.05 / 0.11 \\
(0.02-0.15)\end{array}$ & $\begin{array}{c}0.36 / 0.38 \\
(0.2-0.69)\end{array}$ \\
\hline Total source $\left(\mathrm{TgS} \mathrm{yr}^{-1}\right)$ & $16.1 / 28.7$ & $80 / 90$ \\
\hline Emission & $\begin{array}{c}16.1 / 28.7 \\
(10.7-23.7)\end{array}$ & $\begin{array}{c}65.6 / 64.7 \\
(61.2-92.0)\end{array}$ \\
\hline Chemistry & - & $14.4 / 25.3$ \\
\hline Sink $\left(\operatorname{Tg~Syr}^{-1}\right)$ & $16.1 / 28.7$ & $80 / 89$ \\
\hline Gas-phase oxidation & $16.1 / 28.7$ & $\begin{array}{c}12.3 / 14.6 \\
(6.1-22.0)\end{array}$ \\
\hline Aqueous-phase oxidation & - & $\begin{array}{c}30.8 / 35.8 \\
(24.5-57.8)\end{array}$ \\
\hline Wet deposition & - & $\begin{array}{l}0.36 / 0.4 \\
(0-19.9)\end{array}$ \\
\hline Dry deposition & - & $\begin{array}{c}37 / 38.8 \\
(15.78-55)\end{array}$ \\
\hline Lifetime (days) & $\begin{array}{c}1.2 / 1.5 \\
(0.5-3.0)\end{array}$ & $\begin{array}{c}1.9 / 1.5 \\
(0.6-2.6)\end{array}$ \\
\hline
\end{tabular}

and OM (Stier et al., 2005). For carbonaceous aerosols of biomass burning emissions, a lognormal size distribution is assumed to have a GMD of $150 \mathrm{~nm}$ and a GSD of 1.59 . Note that although the emission size distribution for biofuel emissions is generally assumed to be the same as that for biomass burning emissions (e.g. Dentener et al., 2006), in ModelE2TOMAS run, we assumes the biofuel emission size distributions follow the finer fossil fuel size settings because the CMIP5 emissions does not provide a separate category for biofuel emissions (e.g. biofuel used for cooking and heating are assigned as the residential sector, which also includes fossil fuel usage). The OC (organic carbon): OM (organic matter) ratio is assumed to be $1: 1.4$.

ModelE2-TOMAS assumes larger particles for primary sulfate and carbonaceous aerosols than GISS-TOMAS (e.g. Lee et al., 2013b) to capture the observed aerosol number concentrations better. This is very likely due to the following: (1) GISS-TOMAS attributed the primary sulfate emissions only to anthropogenic sulfur emissions (excluding biomass burning emissions), while ModelE2-TOMAS attributes these to all sulfur emissions; (2) GISS-TOMAS applied the biomass-burning emission size distributions of carbonaceous aerosols to the biofuel emissions, which is coarser than the fossil fuel emission size distribution. Note also that the emission size distributions used for biomass burning and volcanic emissions are finer than the AEROCOM recommendations in Dentener et al. (2006). However, the model number concentrations and size distributions are changed little when applying the AEROCOM recommended emission distributions (not shown). Note that the biomass burning and volcanic emissions for sulfur are 1.4 and $12.5 \mathrm{Tg} \mathrm{S} \mathrm{yr}^{-1}$, respectively.

Following the soil size assumptions used in GISS-TOMAS (Lee et al., 2009), the clay distribution is assumed to have a GMD of $0.14 \mu \mathrm{m}$ and a GSD of 2, and the silt distribution, a GMD of $1.15 \mu \mathrm{m}$ and a GSD of 2. Using this distribution, $15 \%$ of the silt emissions flux falls out of the upper size cutoff (i.e. $10 \mu \mathrm{m}$ ), and is therefore not received by any of the TOMAS size bins.

Compared to the run setup described above (hereafter, referred to as the "BASE" run), we additionally ran two other sensitivity runs with the ModelE2-TOMAS model by perturbing the nucleation process to evaluate changes in number concentrations (Table 1). The first sensitivity run is called "NoNUC", in which we turned off nucleation to estimate the contribution of primary emissions to aerosol number concentrations. The other run is called "LowNUC", in which we reduced the nucleation rate by using 5 times lower sulfuric acid concentrations to compute nucleation rates. Note that sulfuric acid concentrations are not perturbed in other processes, 
and the model sulfuric acid budget is little influenced by this treatment.

\subsection{ModelE2-OMA run setup}

To compare to the ModelE2-TOMAS run, we also ran the ModelE2-OMA model nudged to the same MERRA reanalysis meteorology with 3 years spin-up. However, the natural emissions and associated settings are not always the same between the two models because we chose to maintain the natural emissions/setup used in ModelE2-OMA, which has been chosen carefully in previous studies. To assist the interpretation of the results, we briefly summarize the differences between ModelE2-OMA and ModelE2-TOMAS. First, as mentioned in Sect. 4.1, the ModelE2-OMA model uses the seato-air transfer function of Nightingale et al. (2000) instead of Liss and Merlivat (1986), because Koch et al. (2006) argue that the newer DMS emissions improve sulfate predictions at the remote marine locations. Second, the same seasalt and dust emission schemes are applied in both aerosol models, but different assumptions for the upper limit of particle size are used: $8 \mu \mathrm{m}$ in diameter for sea salt and $16 \mu \mathrm{m}$ in diameter for dust in the ModelE2-OMA model; $10 \mu \mathrm{m}$ in diameter for all species in ModelE2-TOMAS. Third, the ModelE2-OMA model assumes $2.5 \%$ of the total sulfur as primary sulfate as followed by the AEROCOM study (Dentener et al., 2006), whereas ModelE2-TOMAS assumes only $1 \%$. Aerosol number predictions are sensitive to the primary sulfate assumption, but sulfate mass concentrations are not. When using the $2.5 \%$ assumption in ModelE2-TOMAS, we found that the simulated aerosol number concentrations were biased high, and the model size distribution predictions were also poor. Note that Pierce and Adams (2009b) shows that GISS-TOMAS also overpredicts aerosol number concentration with the $2.5 \%$ assumptions.

\section{Model results and evaluation}

In this section, we present global-annual budgets, spatial distributions, and evaluations of the model aerosol precursor gases (in Sect. 5.1), aerosol mass (in Sects. 5.2 and 5.3), aerosol optical depths (AODs; in Sect. 5.4) and aerosol number (in Sects. 5.5 and 5.6). The observations used for model evaluations are from surface-based, aircraft-based and remote-sensing measurements. More details of the observations are provided in each subsection. To compare with the ModelE2-TOMAS results, we included the ModelE2-OMA results in global-annual budgets and model evaluations. Only the BASE run results are used in Sect. 5.1 to 5.4 because the predicted aerosol precursor gases concentrations, aerosol mass concentrations, and AODs from the nucleation sensitivity runs are quite similar to the BASE run.

Model skill is quantified in terms of log-mean normalized bias (LMNB) and log-mean normalized error (LMNE) when evaluating with annual-mean concentration measurements and the normalized mean bias (NMB) and correlation coefficient $(R)$ when evaluating with an observed annual cycle and aerosol optical depth (both monthly and annually averaged AODs).

\subsection{Aerosol precursor gases}

Global budgets of DMS and $\mathrm{SO}_{2}$ in ModelE2-TOMAS are presented in Table 3 with a range obtained from several global models including Wang et al. (2011), Liu et al. (2005), and those listed in Liu et al. (2005). The DMS and $\mathrm{SO}_{2}$ budgets in ModelE2-TOMAS are within the ranges of the other global models. In the case of ModelE2-OMA (in Table 3), the global burden of DMS is about a factor of 2 higher than the ModelE2-TOMAS model, because the DMS emission rate is $\sim 78 \%$ higher by using the sea-to-air transfer functions by Nightingale et al. (2000). Despite the different DMS emissions and $\mathrm{SO}_{2}$ emissions (due to the primary sulfate emission assumption, $1 \%$ versus $2.5 \%$ ), the global burden of $\mathrm{SO}_{2}$ is quite similar to that in the ModelE2-TOMAS model. The dominant $\mathrm{SO}_{2}$ removal processes are aqueous oxidation and dry deposition in both simulations. Boucher et al. (2003) simulate atmospheric DMS in the LMD-ZT model using the same DMS emission schemes as ModelE2-OMA (i.e. EXP1 in their study) and ModelE2-TOMAS (i.e. EXP4 in their study). The global DMS budgets from ModelE2-OMA and ModelE2-TOMAS agree quite well with the EXP1 (within $25 \%$ ) and EXP4 (within 15\%).

When using the same DMS emissions in ModelE2TOMAS as in ModelE2-OMA, the DMS global budgets are almost identical, but the $\mathrm{SO}_{2}$ budgets vary substantially due to the differences in $\mathrm{SO}_{2}$ modelling, i.e. heterogeneous $\mathrm{SO}_{2}$ oxidation and photolysis (see Sect. 2). The heterogeneous sulfur dioxide oxidation on dust aerosol surfaces, which is only included in ModelE2-OMA, accounts for $25 \%$ of the total gas-phase oxidation loss. Based on Bauer and Koch (2005), including the heterogeneous chemistry, global $\mathrm{SO}_{2}$ burden can decrease by $32 \%$, and the global sulfate burden can increase by $3 \%$. The simulated photolysis rates in ModelE2-OMA are affected by aerosol optical depth, affecting hydroxyl $(\mathrm{OH})$ and other gas tracer concentrations - Naik et al. (2013) show a higher OH concentration in ModelE2TOMAS than ModelE2-OMA. Overall, using the same DMS emissions in ModelE2-TOMAS results in a higher $\mathrm{SO}_{2}$ burden and worse agreement for $\mathrm{SO}_{2}$ and sulfate concentrations over remote oceanic regions (not shown).

The global budgets of $\mathrm{H}_{2} \mathrm{SO}_{4}$ and SOA precursor gas in the ModelE2-TOMAS model are not included in Table 3, but are summarized here. The simulated $\mathrm{H}_{2} \mathrm{SO}_{4}$ has a total production rate of $12.3 \mathrm{Tg} \mathrm{Syr}^{-1}$, matching the $\mathrm{SO}_{2}$ gasphase oxidation, and is used in aerosol microphysics (i.e. $12 \mathrm{Tg} \mathrm{yr}^{-1}$ for condensation and $0.3 \mathrm{Tg} \mathrm{yr}^{-1}$ for nucleation). The model SOA precursor gas has a total production rate of $17.1 \mathrm{Tg} \mathrm{yr}^{-1}$, assumed to be $10 \%$ of the terpene emission, 
(a) Column loading [ug S m $\mathrm{m}^{-2}$ ]: DMS

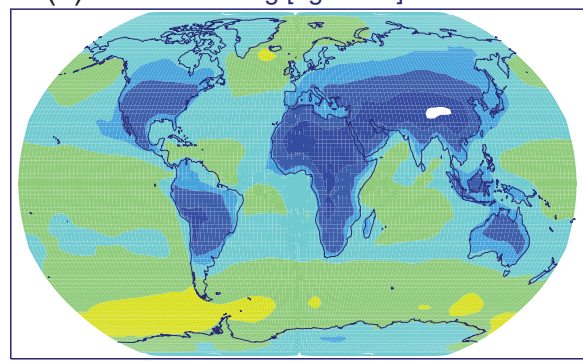

(b) Column loading [ug S m${ }^{-2}$ : SO2

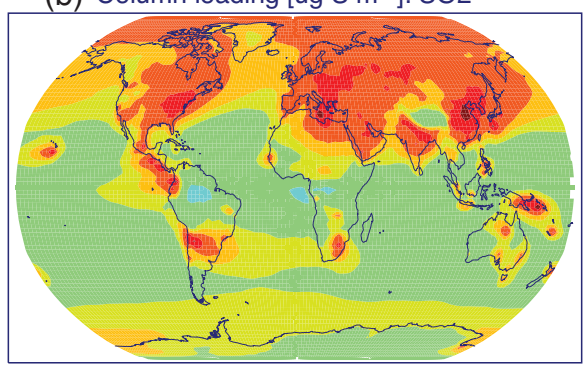

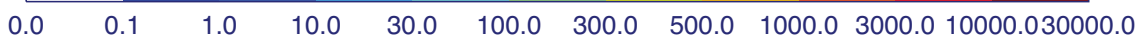

Figure 1. Annual-average column mass concentrations of (a) DMS and (b) $\mathrm{SO}_{2}$ in the ModelE2-TOMAS BASE run. Units are $\mu \mathrm{g} \mathrm{Sm}^{-2}$.

(a) EMEP SO2

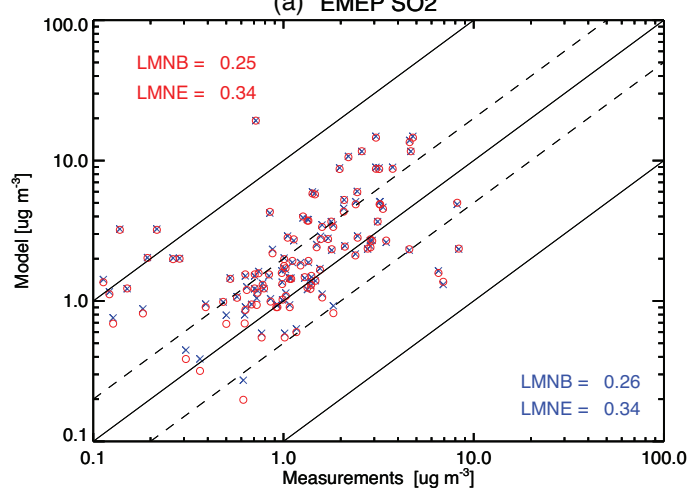

(b) CASTNET SO2

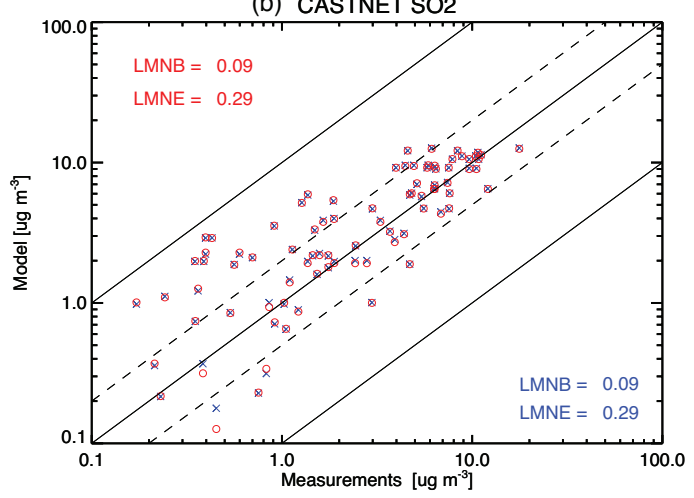

Figure 2. Scatter plot of annual-mean surface $\mathrm{SO}_{2}$ concentrations $\left(\mu \mathrm{g} \mathrm{m}^{-3}\right)$ for the model (red for ModelE2-TOMAS and blue for ModelE2OMA) compared to the observations in the EMEP (European Monitoring and Evaluation Programme, Lovblad et al., 2004; (a)) and CASTNET (Clean Air Status and Trends Network, Malm et al., 2002; (b)) networks. Log-mean normalized bias (LMNB) and log-mean normalized error (LMNE) are given.

and is condensed as hydrophilic OM. For ModelE2-OMA, the total production rate of SOA is $14.6 \mathrm{Tg} \mathrm{yr}^{-1}$. This is quite comparable to ModelE2-TOMAS, which treats SOA much more simply and has a production rate of $17.1 \mathrm{Tg} \mathrm{yr}^{-1}$. The global burden of SOA in ModelE2-OMA is $0.6 \mathrm{Tg} \mathrm{yr}^{-1}$.

Figure 1 shows global maps of annual-mean DMS and $\mathrm{SO}_{2}$ column mass concentrations. The spatial distribution of DMS concentrations shown in Fig. 1a is driven by its emission and interactive $\mathrm{OH}$ and $\mathrm{NO}_{3}$ concentrations, which oxidize DMS to form MSA and $\mathrm{SO}_{2}$. The model DMS concentrations are most pronounced in the Southern and North Atlantic oceans due to high seawater DMS concentrations during summer. The simulated $\mathrm{SO}_{2}$ concentration shown in Fig. $1 \mathrm{~b}$ is very high over industrial regions due to the anthropogenic emissions and is also high over the Southern Ocean due to DMS oxidation. Several local hotspots of $\mathrm{SO}_{2}$ shown in Fig. $1 \mathrm{~b}$ are due to volcanic emissions.

Annually averaged surface-layer $\mathrm{SO}_{2}$ concentrations from both ModelE2-TOMAS and ModelE2-OMA are evaluated against observations from the EMEP (European Monitoring and Evaluation Programme, http://www.emep.int) and
CASTNET (Clean Air Status and Trends Network, http: //epa.gov/castnet/javaweb/index.html) networks (see Fig. 2). We used 2000-2004 mean $\mathrm{SO}_{2}$ measurements for the EMEP network and 1995-2005 mean $\mathrm{SO}_{2}$ data for the CASTNET network. Performance of ModelE2-TOMAS and ModelE2OMA for predicted $\mathrm{SO}_{2}$ concentrations at these locations is almost the same (i.e. $\mathrm{LMNB}=0.25-0.26$ and $\mathrm{LMNE}=0.34$ for the EMEP network; $\mathrm{LMNB}=0.09$ and $\mathrm{LMNE}=0.29$ for the CASTNET network), and the continental $\mathrm{SO}_{2}$ predictions agree with the observation on average roughly within a factor of 2. The two aerosol models are almost the same because the anthropogenic emissions, which are identical in both models, are dominant at these locations.

Figure 3 compares surface-layer $\mathrm{SO}_{2}$ and DMS mixing ratios from the two aerosol models against observations at three Southern Hemisphere remote sites: Amsterdam Island (DMS from Sciare et al., 2001; $\mathrm{SO}_{2}$ from Nguyen et al., 1992), Cape Grim (Ayers et al., 1995), and Dumont (Jourdain and Legrand, 2001). Note that Dumont has only DMS measurements. For DMS, both models capture the observed seasonal cycle (i.e. $R>0.8$ ) generally well, but are less 

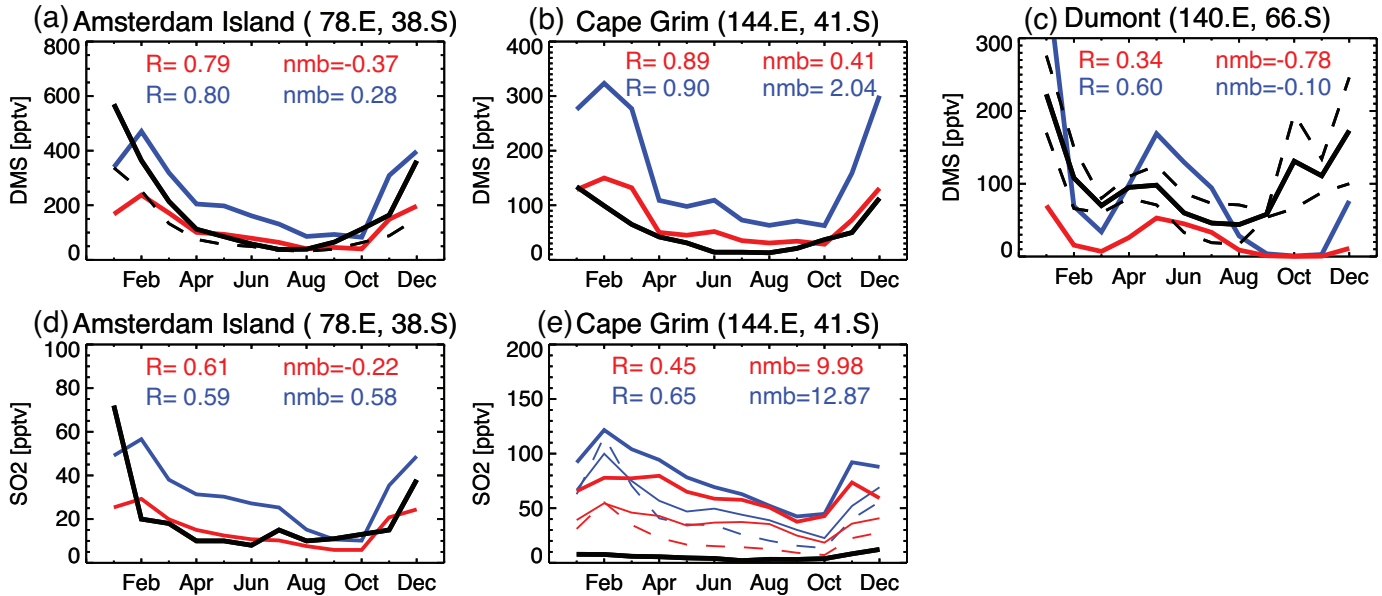

Figure 3. Comparisons of monthly averaged surface DMS (a to c) and $\mathrm{SO}_{2}$ (d to e) mixing ratios (pptv) simulated (red for ModelE2-TOMAS and blue for ModelE2-OMA) and measured (black) at Amsterdam Island (Nguyen et al., 1992) and Cape Grim (Ayers et al., 1991). Only DMS at Dumont D'Urville (Jourdain and Legrand, 2001). Correlation $(R)$ and normalized mean bias (NMB) are given.
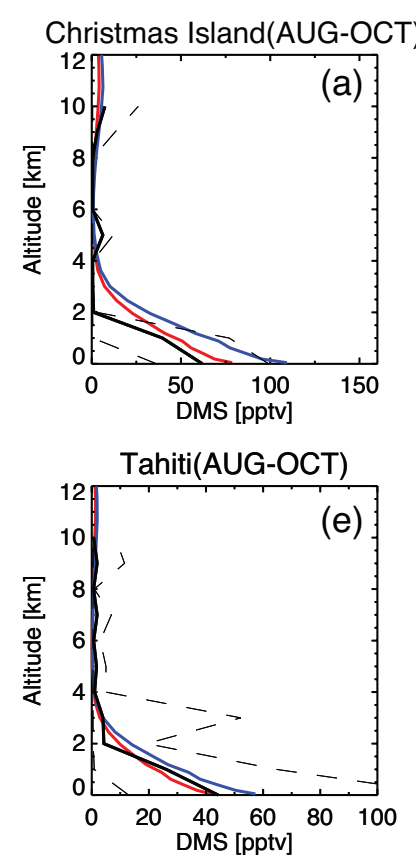
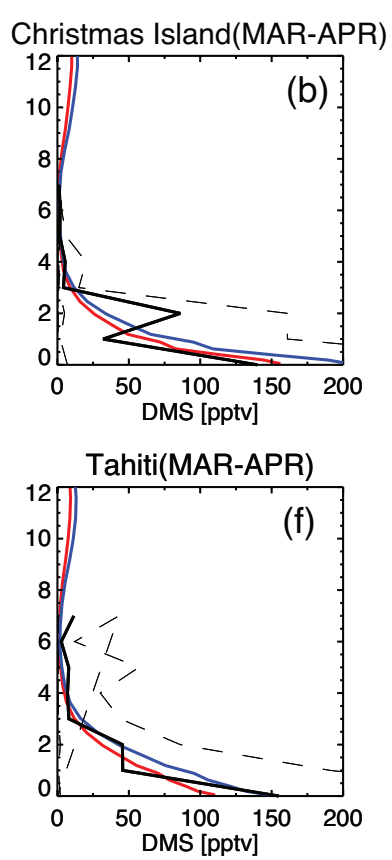

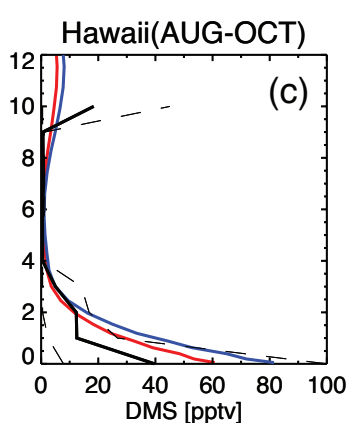

Easter Island(AUG-OCT)

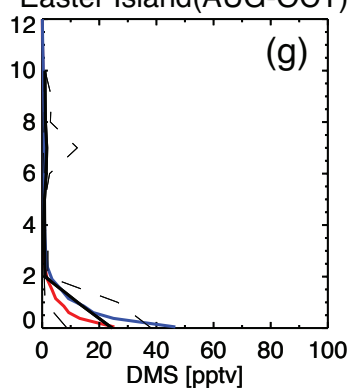

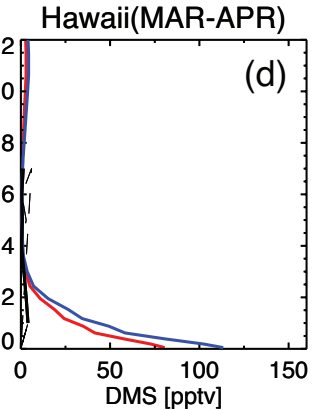

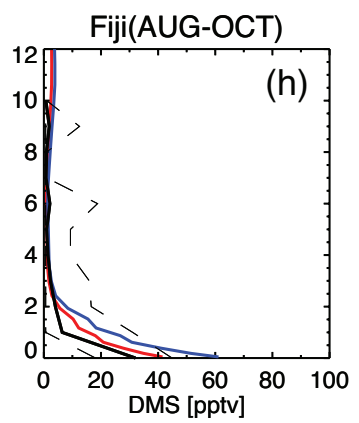

Figure 4. Comparison of DMS vertical profiles over the Pacific Ocean, simulated (red for ModelE2-TOMAS and blue for ModelE2-OMA) and observed (black solid line). Observations are from PEM-Tropic-A (August-October 1996 in the tropical Pacific; Christmas Island in a; Hawaii in c; Tahiti in e; Easter Island in $\mathbf{g}$; Fiji in $\mathbf{h}$ ) and PEM-Tropic-B (March-April 1999 in the tropical Pacific; Christmas Island in b; Hawaii in $\mathbf{d}$; Tahiti in $\mathbf{f}$ ). The dashed lines represent 25 th and 75 th percentiles of the observed values.

successful over Dumont. The DMS concentrations seem to agree well against the observations when using the sea-air transfer function of Liss and Merlivat (1986), i.e. the case for ModelE2-TOMAS, but this run underpredicts during the winter season at the Amsterdam Island site (in Fig. 3a) and during all seasons at the Dumont site (in Fig. 3c). Earlier, we mentioned that the global DMS budgets from Boucher et al. (2003) agree well with those from ModelE2 when using the same DMS emission parameterization. However, Boucher et al. (2003) show the better agreement with the same DMS measurements when using the sea-air transfer function of Nightingale et al. (2000) at Amsterdam Island and Cape Grim (i.e. the case for ModeleE2-OMA), because their DMS mixing ratios from that simulations are actually closer to ModelE2-TOMAS. This may suggest that, at least over SH high-latitude regions, the surface wind speed in 

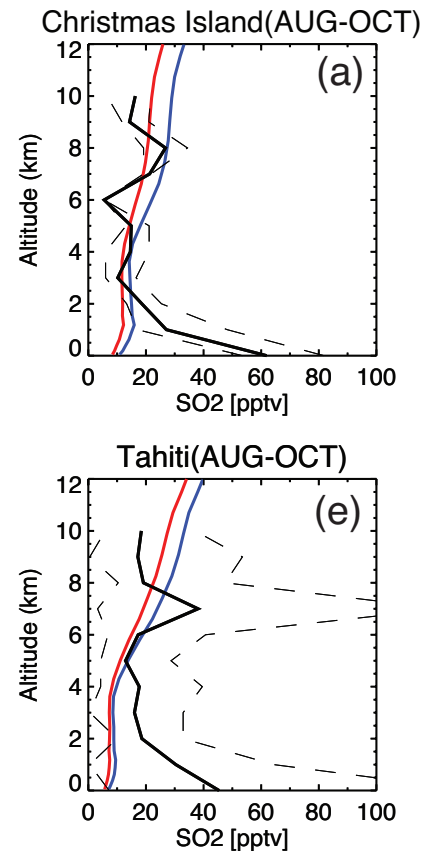
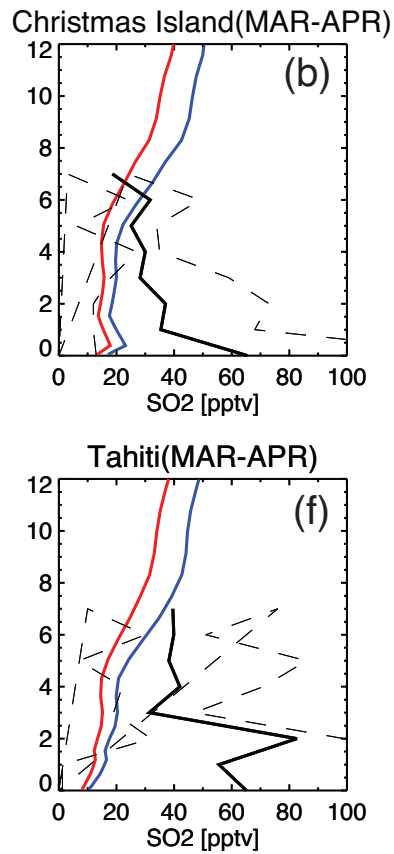
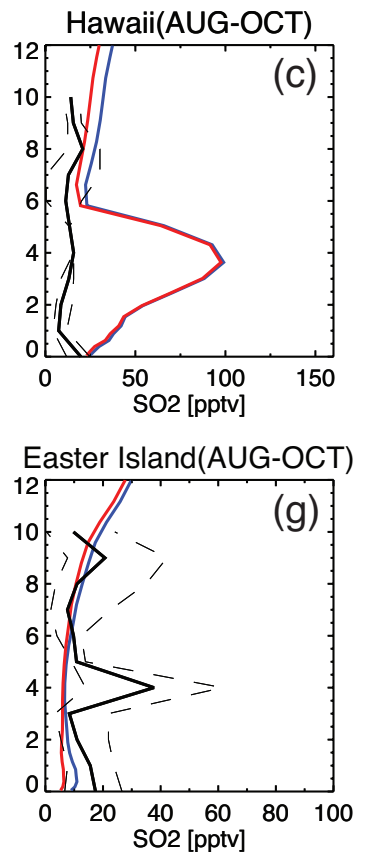
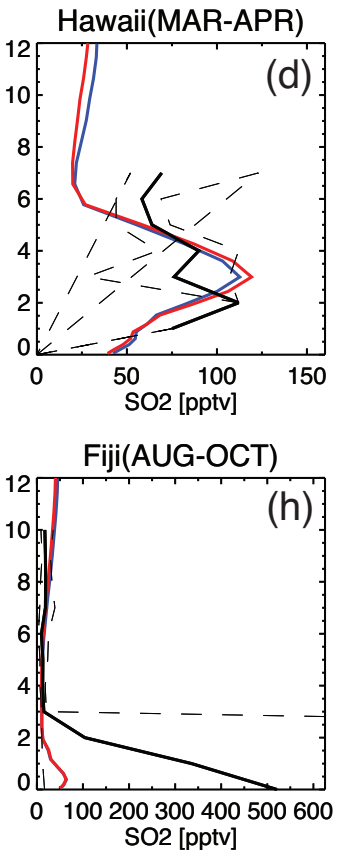

Figure 5. The same as Fig. 4 but for $\mathrm{SO}_{2}$ vertical profiles.

ModelE2 is much stronger than that in LMD-ZT, resulting in higher DMS emissions and burden. We need to investigate further to find out a source for the difference though.

The ModelE2-TOMAS $\mathrm{SO}_{2}$ shows very good agreement at Amsterdam Island but a high bias at Cape Grim (see Fig. $3 \mathrm{~d}$ and e). We considered whether the overpredicted $\mathrm{SO}_{2}$ in the model might be influenced by the emissions in the adjacent grids, which is mentioned in Mann et al. (2010), because the measured $\mathrm{SO}_{2}$ at Cape Grim is filtered to include the marine sector only (Ayers et al., 1991). Sampling the model $\mathrm{SO}_{2}$ from adjacent grids toward marine areas, the overprediction is reduced significantly (LMB is reduced from 10 to 3), but is still severe. The most plausible reason for the overprediction of $\mathrm{SO}_{2}$ at Cape Grim might be the lack of $\mathrm{SO}_{2}$ oxidation by ozone on sea-salt particles, which is missing in our model. Korhonen et al. (2008) show a reduction in $\mathrm{SO}_{2}$ concentrations by a factor of 5 in January and a factor of 20 in July at Cape Grim when including $\mathrm{SO}_{2}$ oxidation on sea-spray particles, although their treatment of the reactions might overestimate the $\mathrm{SO}_{2}$ oxidation rates.

Simulated DMS and $\mathrm{SO}_{2}$ vertical profiles over the Pacific Ocean are compared against two sets of aircraft observations in Figs. 4 and 5: PEM-Tropics-A performed during AugustOctober 1996 (Hoell et al., 1999) and PEM-Tropics-B during March-April 1999 (Raper et al., 2001). Note that PEMTropics-A DC8 aircraft data are used and that most of them were during September 1996, but model evaluation is little changed by comparing them with model outputs in September or the August-October average. The observed vertical profile data used here are binned into altitude ranges (Em- mons et al., 2000). Model outputs are averaged over the observational time period and domain. Simulated DMS vertical profiles are very similar between the two aerosol models, although the surface DMS is different as their emissions are not the same. Both models show good agreement with the observations (mostly within the 25th and 75th percentiles of observed values), especially capturing a strong concentration decrease from the surface to the free troposphere.

In the case of $\mathrm{SO}_{2}$, even though the agreement is not as good as that seen for DMS, both aerosol models seem to capture the observed magnitude approximately within a factor of 2 (see Fig. 5). The overall vertical patterns shown in the models are frequently not in agreement with the observations. Except at Hawaii, our model does not capture the enhanced $\mathrm{SO}_{2}$ concentrations in the boundary layer shown in the observation, even though the model DMS is quite well captured. The poor prediction of the $\mathrm{SO}_{2}$ vertical profile might be due to (1) too much precipitation near the tropics in ModelE2 (see Fig. 9 in Schmidt et al., 2014) and (2) overly strong vertical transport (e.g. via deep convection over the tropical Pacific Ocean) in the model. The latter can be supported by the small DMS peak at $8 \mathrm{~km}$ and the elevated $\mathrm{SO}_{2}$ in the upper/free troposphere in the models (see Figs. 4 and 5). Although the elevated $\mathrm{SO}_{2}$ mixing ratios might be due to wet scavenging (including aqueous chemistry) of $\mathrm{SO}_{2}$ being too weak, we did not see any noticeable improvement when increasing the $\mathrm{SO}_{2}$ Henry's law constant by a factor of 2 in the model (not shown). A large peak in the mid-troposphere at Hawaii in the models results from volcanic $\mathrm{SO}_{2}$ emissions, while the observations show a similar peak only during March-April 1999, 
which is heavily influenced by volcanic emissions (Thornton et al., 1999). During August-October 1996, the observations at Tahiti and Easter Island show transport of volcanic $\mathrm{SO}_{2}$ emissions in the middle and upper troposphere (Thornton et al., 1999), which is not captured in the model. Since our model includes only continuous volcanic emission with a yearly resolution, our model fails to simulate variability in volcanic $\mathrm{SO}_{2}$ emissions at a higher time resolution.

\subsection{Aerosol mass budgets and distributions}

Globally and annually averaged budgets of aerosols in the ModelE2-TOMAS model are shown in Table 4. For the sulfate and EC budgets, we compare with the ACCMIP multi-model mean from Shindell et al. (2013) and Lee et al. (2013a), which is based on 8 ACCMIP models using the same AR5 emission scenario. Note that the biomass burning emission in this study is GFEDv3 inventory averaged from 1997 to 2009, while the ACCMIP models use GFEDv2 inventory averaged from 1997 to 2006 . We do not compare with the AEROCOM phase 2 multi-model mean presented in Myhre et al. (2013a) because the aerosol budgets in Myhre et al. (2013a, b) are for anthropogenic aerosols, which is defined as the difference between the present-day run and pre-industrial run. For the lifetime and deposition rate coefficient budgets, we compare with the AEROCOM Phase 1 multi-model mean presented in Textor et al. (2006) - hereafter, referred to as AEROCOM Phase 1. For sulfate, the ModelE2-TOMAS total source rate is lower than the ACCMIP mean (43.7 vs. $51.7 \mathrm{Tg} \mathrm{S} \mathrm{yr}^{-1}$ ), and the global burden is the same as the ACCMIP mean burden $(0.67 \mathrm{TgS})$ due to the slightly longer lifetime in the ModelE2-TOMAS model (5.7 vs. 5.0 days). Note that the GISS-E2-R-TOMAS model used for ACCMIP is almost identical to ModelE2-TOMAS evaluated here except for the sulfate modelling. The sulfate and DMS emissions used in GISS-E2-R-TOMAS are identical to those used in ModelE2-OMA in this paper. For dry deposition coefficient (the inverse of the lifetime), ModelE2TOMAS has a particularly small value. However, the longer overall sulfate lifetime is contributed by both dry and wet deposition, rather than dry deposition. When increasing the dry deposition coefficient to the AEROCOM Phase 1 mean alone, the overall lifetime is decreased from 5.6 to 4.8 days. Doing the same for wet deposition with no change in the dry deposition, the overall lifetime decreases from 5.6 to 4.5 days. Wet deposition accounts for $98 \%$ of the total deposition in ModelE2-TOMAS, which is much higher than AEROCOM Phase 1, and convective clouds contribute $27 \%$ of the wet deposition.

Global annual EC in ModelE2-TOMAS is $0.19 \mathrm{Tg}$, which is very comparable to the ACCMIP mean $(0.16 \mathrm{Tg})$. Similar to sulfate, wet deposition contributes $>95 \%$ of total deposition of EC, which is higher than other ACCMIP models (see Table 3 in Lee et al., 2013a), and 24\% of wet deposition is by convective clouds. For EC and OM, their lifetimes are longer than the ACCMIP mean as well as AEROCOM Phase 1 means but still within the standard deviation. Despite smaller dry deposition coefficients for EC and OM compared to the AEROCOM mean, their wet deposition coefficients are quite comparable to the AEROCOM mean.

The global annual burdens of sea salt and dust in ModelE2-TOMAS are 3.6 and $9.1 \mathrm{Tg}$, respectively. For sea salt and dust, dry deposition is as important as wet deposition due to their large particle sizes, accounting for 68 and $52 \%$ of total deposition, respectively. Since the size coverages of sea salt and dust in our model do not necessarily match with those in the AEROCOM Phase 1 models, we do not compare the lifetime and removal rate coefficients, which is strongly influenced by the upper size cutoff used in their emissions.

Despite the same host model and the same anthropogenic emission scenarios as the ModelE2-TOMAS model, the ModelE2-OMA model shows significantly different aerosol mass budgets (in Table 5), which must arise from using different deposition assumptions and other aerosol modelling treatments (see Sect. 2 for the details). Sulfate burden and lifetime in ModelE2-OMA is roughly half of that in ModelE2-TOMAS. The total source rate of $\mathrm{SO}_{4}$ is about $20 \%$ higher than ModelE2-TOMAS and is close to the ACCMIP mean value. The ModelE2-OMA model has a shorter lifetime for EC, leading to a 40\% lower burden compared to ModelE2-TOMAS. The OM burden is quite similar between two models. SOA formation rate is slightly different $\left(14.6 \mathrm{Tg} \mathrm{yr}^{-1}\right.$ for ModelE2-OMA and $17.1 \mathrm{Tg} \mathrm{yr}^{-1}$ for ModelE2-TOMAS), but the difference is only a small portion (about 3-4\%) of the total OM source rate. The seasalt emission rate is lower than that in ModelE2-TOMAS due to the maximum size cutoff of $8 \mu \mathrm{m}$ assumed in sea-salt emission, but its burden is more than a factor of 2 higher. For dust particles, the emission rate is higher than that in ModelE2-TOMAS due to the coarser size cutoff in their emissions (i.e. up to $16 \mu \mathrm{m}$ ), and the burden is higher. For sea salt, the contribution of wet deposition to total deposition is more than 2 times higher than that in ModelE2TOMAS. Unlike ModelE2-TOMAS, ModelE2-OMA has nitrate aerosol, which has a global burden of $1.6 \mathrm{Tg}$ with a lifetime of 6.4 days.

The removal rate coefficient of dry deposition is about 5060 times higher for sulfate, EC and OM in ModelE2-OMA, making it more comparable to the AEROCOM mean values. The lower dry deposition rates with the ModelE2-TOMAS model is likely due to the size-dependent dry deposition parameterization. The dry deposition velocity is not saved in the ModelE2 output currently, so alternatively we refer to the Fig. 1 in Adams and Seinfeld (2002) that presents the global and annual-average of size-resolved dry deposition velocities in GISS-TOMAS (sulfate alone) compared to the size-independent one. Although the dry deposition velocities from ModelE2-TOMAS might not be exactly the same as the ones in the model version used in Adams and Seinfeld (2002) due to the updates made in ModelE2 (e.g. the 
Table 4. Global aerosol budgets of the BASE run in ModelE2-TOMAS. Values in the parentheses are the mean and normalized standard deviations obtained from Table 10 in Textor et al. (2006). The mass budgets for sulfate are presented as $\mathrm{TgS}$.

\begin{tabular}{|c|c|c|c|c|c|}
\hline & Sulfate & Elemental carbon (EC) & Organic matter $(\mathrm{OM})$ & Sea salt & Dust \\
\hline Burden $(\mathrm{Tg})$ & 0.67 & 0.19 & 1.2 & 3.6 & 9.1 \\
\hline Total source $\left(\mathrm{Tg} \mathrm{yr}^{-1}\right)$ & 43.7 & 7.4 & 60.8 & 3231.9 & 705.8 \\
\hline Emission & 0.66 & 7.4 & 43.7 & 3231.9 & 705.8 \\
\hline Wet deposition $\left(\mathrm{Tg} \mathrm{yr}^{-1}\right)$ & 42.9 & 7.1 & 59.1 & 1046.9 & 336.8 \\
\hline By convective clouds (\%) & 27 & 24 & 24 & 54 & 29 \\
\hline Dry deposition $\left(\mathrm{Tg}_{\mathrm{yr}}{ }^{-1}\right)$ & 0.8 & 0.3 & 1.6 & 2184.9 & 369.9 \\
\hline Lifetime (days) & $\begin{array}{c}5.6 \\
(4.1,18 \%)\end{array}$ & $\begin{array}{c}9.6 \\
(7.1,33 \%)\end{array}$ & $\begin{array}{c}7.2 \\
(6.5,27 \%)\end{array}$ & $\begin{array}{c}0.4 \\
(0.5,58 \%)\end{array}$ & $\begin{array}{c}4.7 \\
(4.1,43 \%)\end{array}$ \\
\hline Removal rate coefficient $\left(\right.$ day $\left.^{-1}\right)$ & $\begin{array}{c}0.18 \\
(0.25,18 \%)\end{array}$ & $\begin{array}{c}0.1 \\
(0.15,21 \%)\end{array}$ & $\begin{array}{c}0.14 \\
(0.16,24 \%)\end{array}$ & $\begin{array}{c}2.4 \\
(5.1,188 \%)\end{array}$ & $\begin{array}{c}0.21 \\
(0.31,62 \%)\end{array}$ \\
\hline Wet deposition & $\begin{array}{c}0.18 \\
(0.22,22 \%)\end{array}$ & $\begin{array}{c}0.1 \\
(0.12,31 \%)\end{array}$ & $\begin{array}{c}0.14 \\
(0.14,32 \%)\end{array}$ & $\begin{array}{c}0.79 \\
(0.79,77 \%)\end{array}$ & $\begin{array}{c}0.1 \\
(0.08,42 \%)\end{array}$ \\
\hline Dry deposition & $\begin{array}{c}0.0032 \\
(0.03,55 \%)\end{array}$ & $\begin{array}{c}0.004 \\
(0.03,55 \%)\end{array}$ & $\begin{array}{c}0.0037 \\
(0.03,49 \%)\end{array}$ & $\begin{array}{c}1.6 \\
(4.3,219 \%)\end{array}$ & $\begin{array}{c}0.11 \\
(0.23,84 \%)\end{array}$ \\
\hline Wet/(Wet + Dry) (\%) & $\begin{array}{c}98 \\
(89,8 \%)\end{array}$ & $\begin{array}{c}96 \\
(79,17 \%)\end{array}$ & $\begin{array}{c}97 \\
(80,16 \%)\end{array}$ & $\begin{array}{c}32 \\
(31,65 \%)\end{array}$ & $\begin{array}{c}48 \\
(33,54 \%)\end{array}$ \\
\hline
\end{tabular}

Table 5. Global aerosol budgets in ModelE2-OMA. Note that the sulfate and nitrate budgets are presented as Tg S and Tg N, respectively.

\begin{tabular}{|c|c|c|c|c|c|c|}
\hline & Sulfate & $\mathrm{EC}$ & $\mathrm{OM}$ & Sea salt & Dust & Nitrate \\
\hline Burden (Tg) & 0.38 & 0.12 & 1.1 & 9.3 & 11.4 & 0.37 \\
\hline Total source $\left(\operatorname{Tg~yr}^{-1}\right)$ & 52.0 & 7.4 & 58.5 & 2866.7 & 1071.8 & 21.0 \\
\hline Emission & 1.7 & 7.4 & 43.7 & 2866.7 & 1071.8 & \\
\hline Wet deposition $\left(\mathrm{Tg} \mathrm{yr}^{-1}\right)$ & 46.6 & 5.4 & 44.9 & 2059.1 & 407.7 & 17.7 \\
\hline By convective clouds (\%) & 21 & 37 & 32 & 39 & 52 & 29 \\
\hline Dry deposition $\left(\mathrm{Tg} \mathrm{yr}^{-1}\right)$ & 5.4 & 2.0 & 13.7 & 806.9 & 664.1 & 3.3 \\
\hline Lifetime (days) & 2.6 & 5.8 & 7.1 & 1.2 & 3.9 & 6.4 \\
\hline Removal rate coefficient $\left(\right.$ day $\left.^{-1}\right)$ & 0.39 & 0.17 & 0.14 & 0.84 & 0.26 & 0.16 \\
\hline Wet deposition & 0.35 & 0.13 & 0.11 & 0.61 & 0.10 & 0.13 \\
\hline Dry deposition & 0.04 & 0.046 & 0.033 & 0.24 & 0.16 & 0.025 \\
\hline Wet/(Wet + Dry) $(\%)$ & 90 & 73 & 77 & 72 & 38 & 84 \\
\hline
\end{tabular}

boundary layer module), this point should be valid because the dry deposition parameterizations in both models have been little changed. Despite the large differences in dry deposition rates for accumulation mode particles, dry deposition is a fairly minor removal pathway in both models.

Figure 6 shows simulated global distributions of annualmean concentrations of ModelE2-TOMAS sulfate, EC, OM, sea salt and dust in the lowermost layer. The sulfate concentrations are high over industrial regions, driven by the $\mathrm{SO}_{2}$ emissions and $\mathrm{OH} / \mathrm{H}_{2} \mathrm{O}_{2}$ oxidant concentrations. Simulated $\mathrm{EC}$ and $\mathrm{OM}$ concentrations are high over the biomass burning regions and the industrial regions, especially East Asia and South Asia, but the OM concentrations are particularly pronounced over biomass burning regions due to their higher emissions. Due to the SOA formation, the OM concentra- tions over Midwest US and central Siberia are also noticeably high. The sea-salt concentrations are distributed fairly uniformly over the oceans, but are higher over the Southern Ocean and lower over the oceans near the tropics, as expected due to wind speed variations. The dust concentrations are pronounced over the source regions such as northern Africa, Arabia, northern/northwestern China, and Australia.

Figure 7 shows zonal distributions of annual-mean aerosol concentrations in ModelE2-TOMAS. The sulfate concentrations are highest between 0 and $50^{\circ} \mathrm{N}$ due to the high anthropogenic emissions in the Northern Hemisphere (NH). Over the SH, the sulfate concentrations are mostly a result of DMS oxidation. The zonal-mean EC and OM concentrations are high from the tropics to $\sim 50^{\circ} \mathrm{N}$. Similar to Fig. 6 , the high $\mathrm{EC}$ and $\mathrm{OM}$ concentrations are around 30 to $50^{\circ} \mathrm{N}$ due 
Table 6. Statistical measures of model predictions compared to satellites. For ModelE2-OMA, the model prediction without nitrate aerosols is also presented in parentheses.

\begin{tabular}{llccc}
\hline & & Model vs. MODIS & Model vs. MISR & MODIS vs. MISR \\
\hline \multirow{2}{*}{ ModelE2-TOMASS } & Correlation & 0.63 & 0.73 & 0.79 \\
& NMB $(\%)$ & $-29 \%$ & $-34 \%$ & $8 \%$ \\
\multirow{2}{*}{ ModelE2-OMA } & Correlation & $0.45(0.45)$ & $0.52(0.55)$ & 0.79 \\
& NMB $(\%)$ & $16 \%(-16 \%)$ & $8 \%(-21 \%)$ & $8 \%$ \\
\hline
\end{tabular}
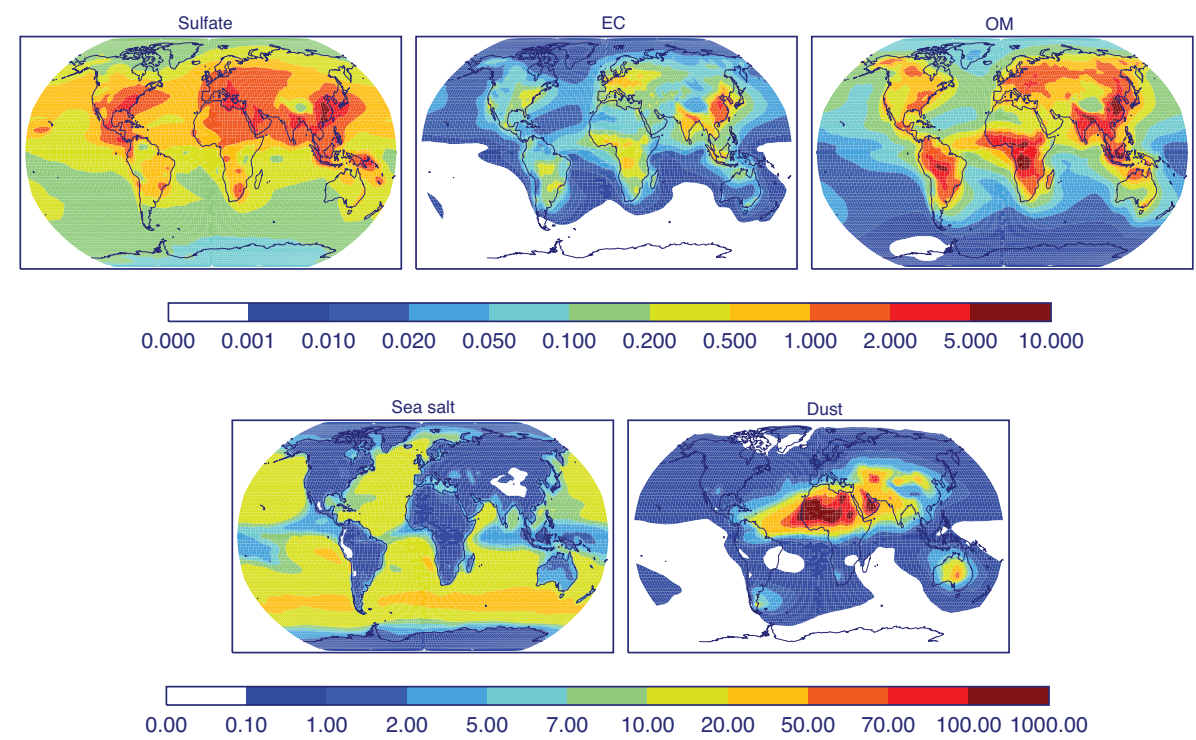

Figure 6. Annual-mean concentrations of (a) sulfate, (b) EC, (c) OM, (d) sea salt, and (e) dust in the lowermost layer in the ModelE2TOMAS BASE run. Units are $\mu \mathrm{g} \mathrm{m}^{-3}$.

to fossil fuel emissions, but the OM concentrations are also large around the tropics due to biomass burning emissions. The two small spikes showing the EC and OM concentrations between $10^{\circ} \mathrm{S}$ and $10^{\circ} \mathrm{N}$ are a result of the injection height used in the biomass burning emissions. Since a significant amount of sulfate and OM is also formed through chemical reactions in the atmosphere, their vertical gradients are relatively small. The sea-salt concentrations are high, from $60^{\circ} \mathrm{S}$ to $50^{\circ} \mathrm{N}$ with a peak around 30 to $60^{\circ} \mathrm{S}$, due to the large open ocean in the SH. A strong dust plume is shown at around 0$30^{\circ} \mathrm{N}$ due to the large northern African and Middle East dust emissions, and a small dust plume at around $30^{\circ} \mathrm{S}$ due to Australian emissions. In the model, the $\mathrm{PM}_{10}$ concentrations in the upper troposphere are dominated by sulfate and dust particles.

\subsection{Aerosol mass concentration evaluation}

The simulated surface-layer mass concentrations of aerosols are evaluated against various observations: (1) sulfate/seasalt/dust concentrations at 23 long-term observation sites operated by the University of Miami (e.g. Prospero and Bonatti, 1969; Savoie and Prospero, 1989; Arimoto et al.,
1990); (2) speciated $\mathrm{PM}_{2.5}$ concentrations from the Interagency Monitoring of Protected Visual Environment (IMPROVE) sites in the United States that are annual averages from 2000 to 2008 (Debell et al., 2006; Hand et al., 2011); (3) speciated $\mathrm{PM}_{2.5}$ concentrations from various European observations (Putaud et al., 2010) (hereafter, referred to as European sites); (4) a large set of $\mathrm{PM}_{2.5}$ observations assembled in support of the Global Burden of Disease Study (GBD Study 2010, http://www.globalburden.org); and (5) deposition flux measurements obtained from Ginoux et al. (2001), Tegen et al. (2002), and Mahowald et al. (2009). The $\mathrm{PM}_{2.5}$ data set from the GBD Study consists of a worldwide set of annual-average $\mathrm{PM}_{2.5}$ largely drawn from official monitoring networks for 2005 (in some cases from 2004 to 2006). The GBD PM 2.5 data set includes the IMPROVE network and the European site measurements, so we only present the $\mathrm{PM}_{2.5}$ evaluation with the GBD data set. For details of the GBD $\mathrm{PM}_{2.5}$ data set, the reader is referred to the description in the supplementary material in Shindell et al. (2011).

Figure 8 compares the model annual-mean surface-layer sulfate mass concentrations to the observations from the IMPROVE network, the European sites, and the University of Miami network. Simulated sulfate agrees well with 

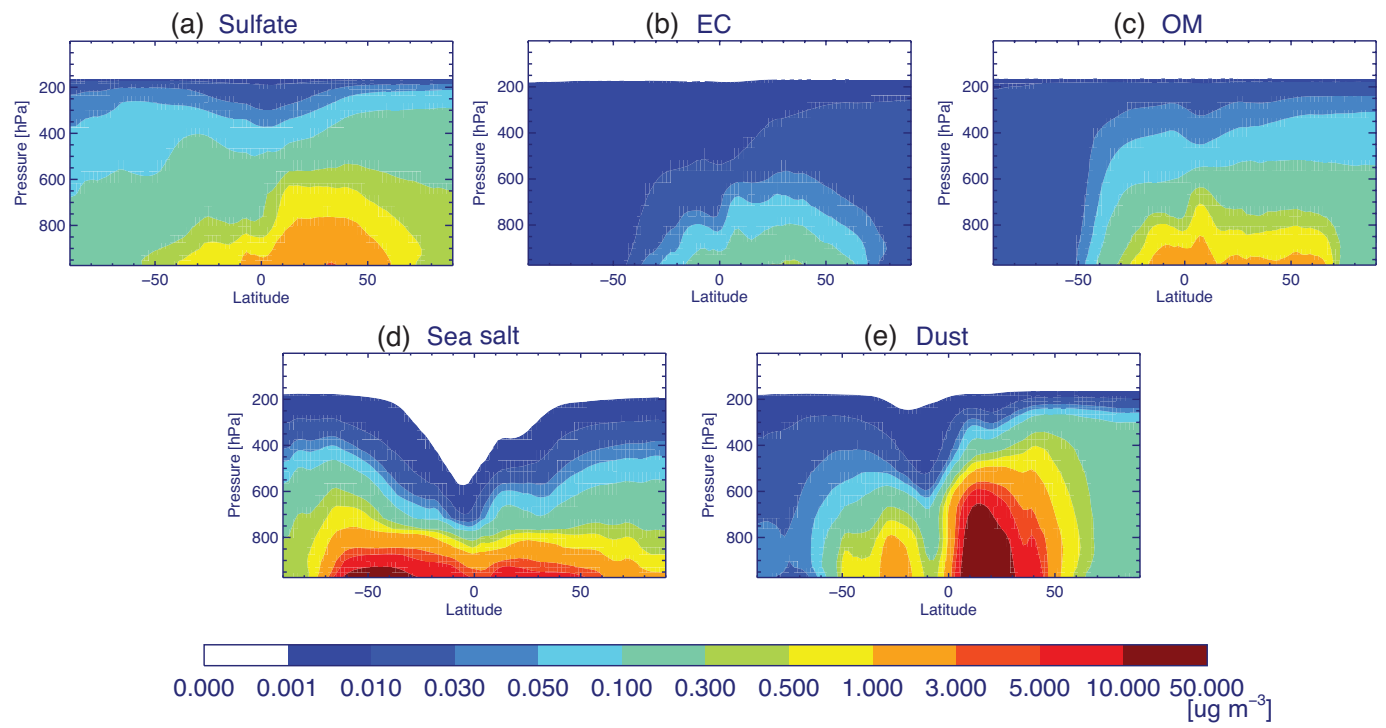

Figure 7. Annually and zonally averaged concentrations of (a) sulfate, (b) EC, (c) OM, (d) sea salt, and (e) dust in the ModelE2-TOMAS BASE run. Units are $\mu \mathrm{g} \mathrm{m}^{-3}$.
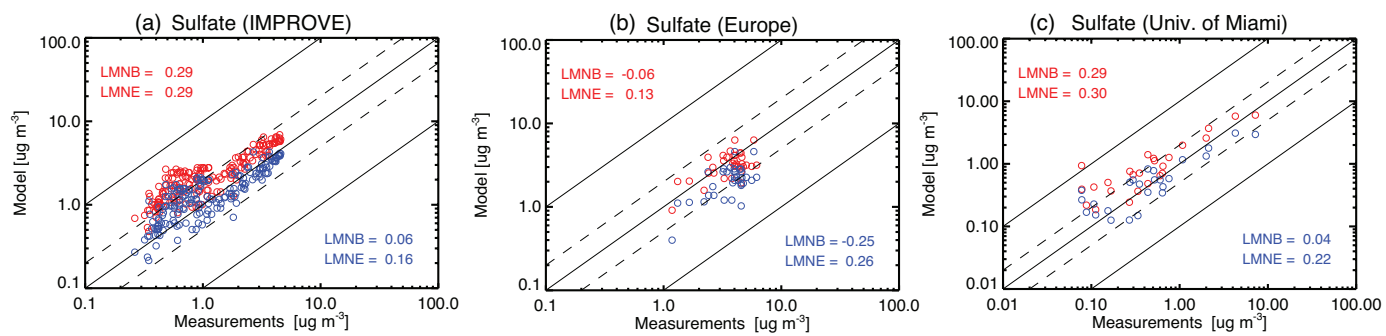

Figure 8. Scatter plot of annually averaged surface sulfate mass concentrations $\left(\mu \mathrm{g} \mathrm{m}^{-3}\right.$ ) in the model (red for ModelE2-TOMAS and blue for ModelE2-OMA) and observation from (a) the IMPROVE network, (b) the European sites from Putaud et al. (2010), and (c) the University of Miami. Note that the sulfate in the model is simply converted to ammonium sulfate at the IMPROVE sites.

observations, mostly within a factor of 2. Compared to ModelE2-OMA, the ModelE2-TOMAS model shows better agreement at the European sites (i.e. $\mathrm{LMNB}=-0.06$ and $\mathrm{LMNE}=0.13$ in Fig. $8 \mathrm{~b}$ ) but worse at the IMPROVE sites (i.e. $\mathrm{LMNB}=0.29$ and $\mathrm{LMNE}=0.29$ in Fig. $8 \mathrm{a}$ ) and the remote oceanic sites (i.e. $\mathrm{LMNB}=0.29$ and $\mathrm{LMNE}=0.30$ in Fig. 8c). Over the US, both models overpredict systematically at lower observed concentrations (i.e. below $1 \mu \mathrm{g} \mathrm{m}^{-3}$ of measured $\mathrm{SO}_{4}$ concentrations), which are mostly located over the western US.

Monthly mean surface-layer sulfate concentrations are evaluated using observations from the University of Miami in Fig. 9. The simulated sulfate mass concentrations from both models usually falls within the standard deviation of the observed values. The sulfate predictions in both ModelE2OMA and ModelE2-TOMAS become quite similar over the SH because about a factor of 2 lower DMS emissions are used in ModelE2-TOMAS. Using the same DMS emissions as ModelE2-OMA, ModelE2-TOMAS tends to overpredict sulfate concentrations noticeably over the SH (not shown), and the higher $\mathrm{SO}_{4}$ concentration with ModelE2-TOMAS could be explained by (1) a longer lifetime due to different deposition parameterizations, (2) letting all $\mathrm{SO}_{4}$ formed from aqueous oxidation to evaporate without accounting for cloud evaporation, (3) a stronger oxidation state resulted from undegraded photolysis rates by aerosol optical depth (more $\mathrm{SO}_{4}$ can be formed from DMS oxidation). Despite the fact that ModelE2-OMA accounts for the heterogeneous $\mathrm{SO}_{4}$ formation on dust particles, $\mathrm{SO}_{4}$ concentrations in near dust source regions are still higher in the ModelE2-TOMAS model due to the shorter lifetime in the ModelE2-OMA model.

Simulated annual-mean surface-layer sea-salt concentrations are evaluated with the IMPROVE network, the European sites, and the University of Miami network (Fig. 10). Both aerosol models are biased strongly high over the US and Europe but biased low near the tropics. Unlike ModelE2OMA, ModelE2-TOMAS underpredicts sea-salt concentrations at several remote sites (see Fig. 10c). Compared to other aerosol components, the agreement between model sea salt and the observations is worse over the United States and 

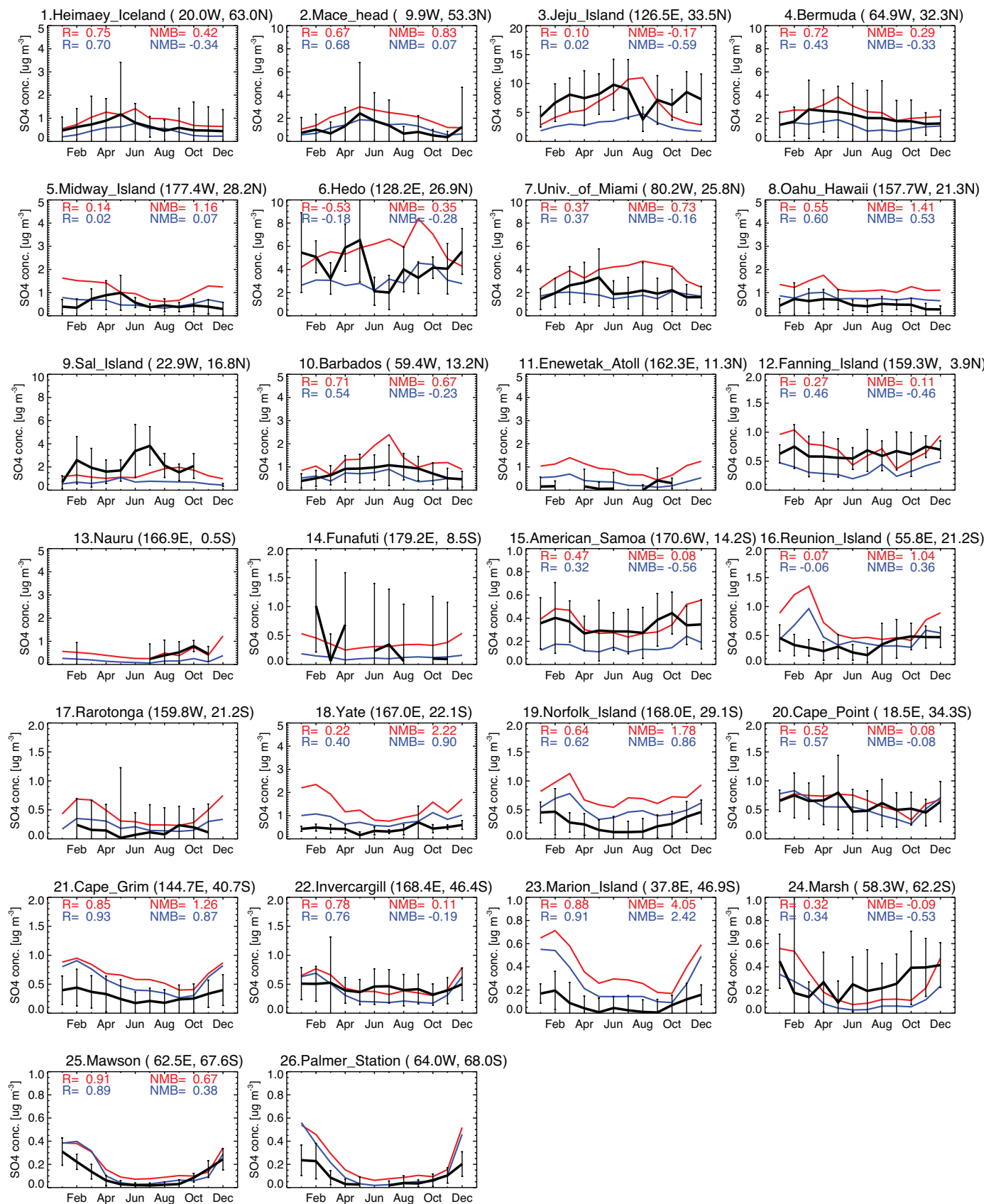

Figure 9. Comparisons of monthly averaged surface sulfate mass concentrations $\left(\mu \mathrm{g} \mathrm{m}^{-3}\right)$ simulated (red for ModelE2-TOMAS and blue for ModelE2-OMA) and measured (black solid line with an error bar showing a standard deviation) by the University of Miami. Correlation $(R)$ and normalized mean bias (NMB) are provided only when the observation is available for 12 months.

Europe. For the evaluation of monthly mean surface-layer sea-salt concentrations against the University of Miami data set in Fig. 11, the model predictions fall within the observed standard deviation at about a half of the 26 sites, but these sites are not necessarily the same between the two aerosol models. The overprediction of sea salt in continents may suggest that ModelE2 has a stronger transport from ocean to in-land, as there is no obvious overprediction over adjacent oceanic sites. The ModelE2-OMA model exhibits a particularly large overprediction over most SH sites. Both models tend to be biased significantly low at some of the sites near the tropics where the observed sea-salt concentrations are high. Similar underprediction is also shown in mineral dust (see Fig. 13). This might be due to fast wet scavenging due to overpredicted precipitation in that area (see Fig. 9 in Schmidt et al., 2014). 

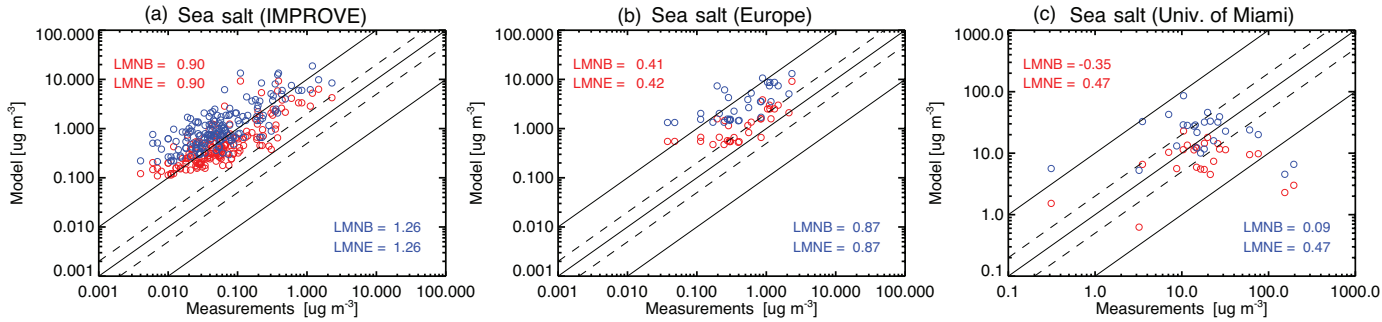

Figure 10. Same as Fig. 8 but for sea-salt mass concentrations.
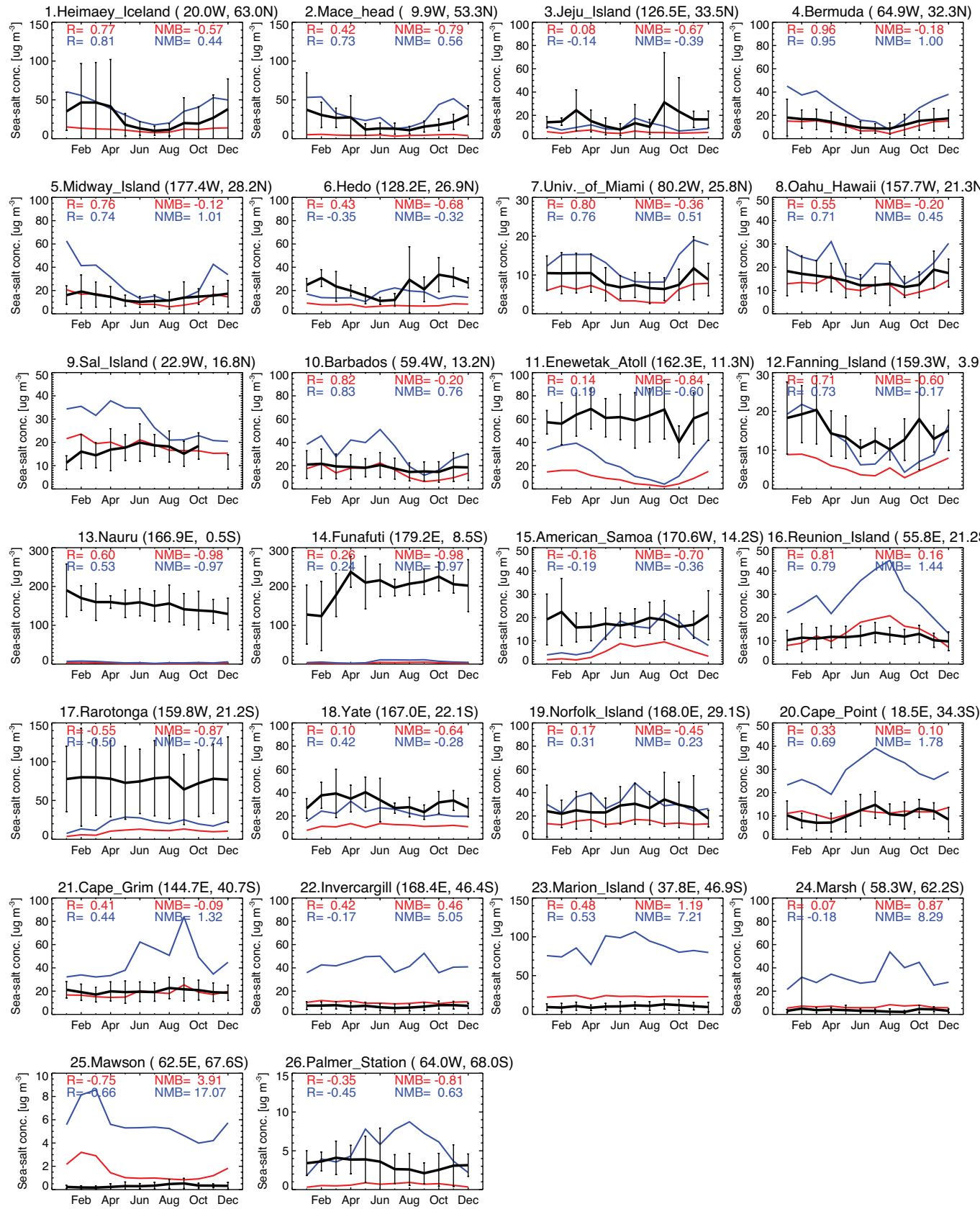

Figure 11. Same as Fig. 9 but for sea-salt mass concentrations. 

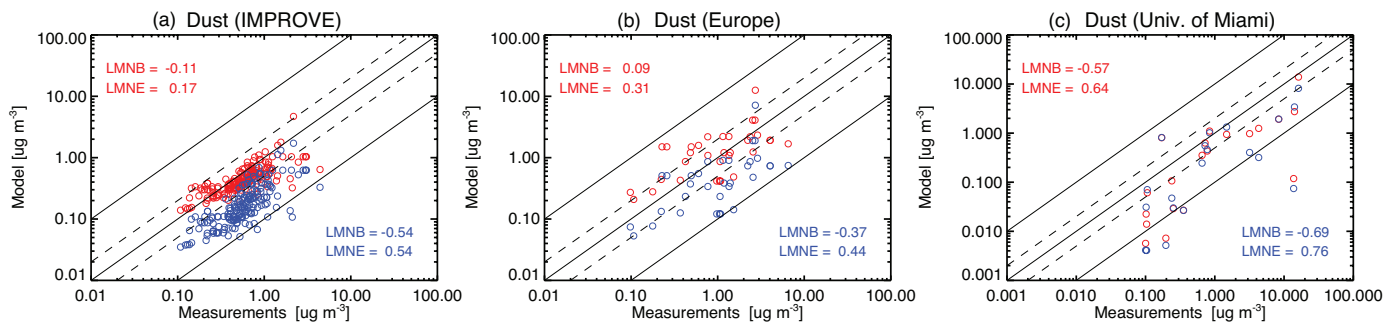

Figure 12. Same as Fig. 8 but for dust mass concentrations.
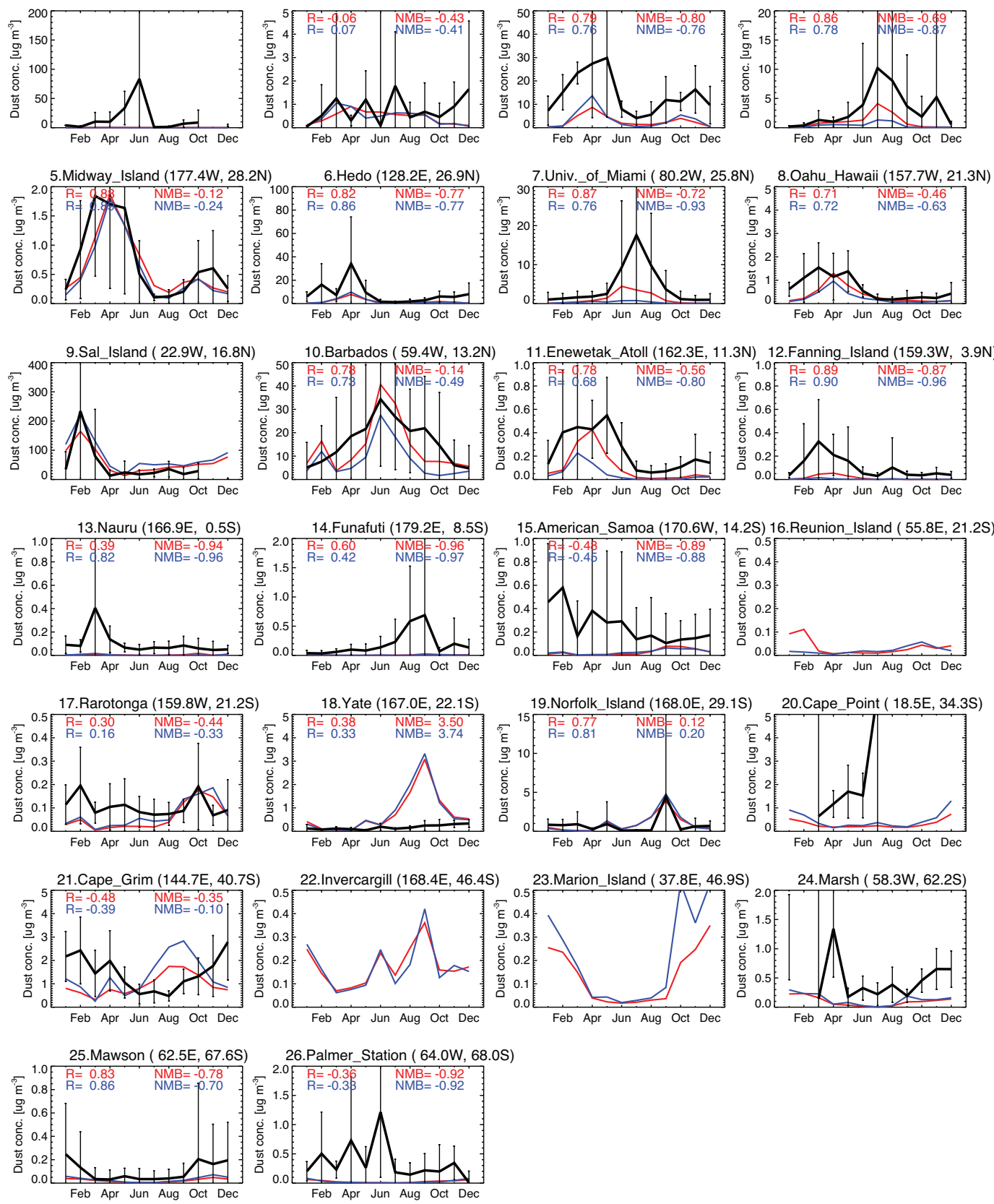

Figure 13. Same as Fig. 9 but for dust mass concentrations. 
For ModelE2-TOMAS, simulated annual-mean surfacelayer dust concentrations are mostly within a factor of 2 of the measurements (in Fig. 12): six sites are excluded in Fig. 12 due to an incomplete annual cycle. ModelE2TOMAS shows good agreement at the IMPROVE and European sites, while ModelE2-OMA tends to underpredict. This is due to the emission size assumptions (resulting in more clay emissions than ModelE2-OMA) and the differences in the deposition parameterizations (resulting in slightly longer lifetime for clay particles; $\sim 9$ days in ModelE2-TOMAS and 6.5 days in ModelE2-OMA). Both models are biased low compared to the University of Miami data set, and only 7-8 sites among 20 sites fall within a factor of 2 agreement. A few sites show a severe underprediction for both models, mostly located near the tropics and at SH high latitudes.

Monthly mean surface-layer dust concentrations are evaluated using the observations from the University of Miami in Fig. 13: no measurement data are available at three sites (Reunion Island, Invercargill, and Marion Island), but we still include them to compare the two aerosol model predictions. The model captures the observed annual cycle of dust very well at most NH sites but not at the SH sites, except Norfolk and Mawson. The model captures the observed magnitude well at sites located relatively near the source regions (e.g. Sal Island, Barbados, Bermuda for African dust; Jeju Island and Hedo for Asian dust; Cape Grim and Norfolk Island for Australian dust). Both models underpredict dust concentrations in the $\mathrm{NH} / \mathrm{SH}$ high latitude $\left(45^{\circ}\right)$ regions except Mace Head, but the simulated dust seems to be within the observed standard deviation as the observations have a large standard deviation for dust. The observed peak concentration at Heimaey Iceland is the second highest after Sal island. Our models underpredict this site severely, probably because our dust emission parameterization is not designed to simulate a dust event in humid areas such as Iceland. Prospero et al. (2012) point out that dust emissions at high latitudes (e.g. Alaska and Iceland) are mostly due to individual dust events or single seasons and link large dust events at Heimaey Iceland during 1997 to 2002 with glacial outburst floods.

Figure 14 compares simulated annual-mean dust deposition fluxes against observations obtained from Ginoux et al. (2001), Tegen et al. (2002), and Mahowald et al. (2009). Data are classified by the influencing source region, presented in different colours in Fig. 14. Except for the minor source category, the model dust deposition fluxes tend to be underestimated at most locations and agree with observations only within a factor of 5-8 on average. This may indicate that dust emissions are too low in ModelE2, but deposition fluxes measurements could contain large particles especially close to source regions (e.g. Duce, 1995) or local emissions (Uematsu et al., 1985) that are not simulated in the model. For ModelE2-TOMAS, the upper size limit being $10 \mu \mathrm{m}$, which is too small for the dust particles near the sources, can explain some of the severe underprediction, and Lee et al. (2009) also show similar disagreement using the GISS-TOMAS model.

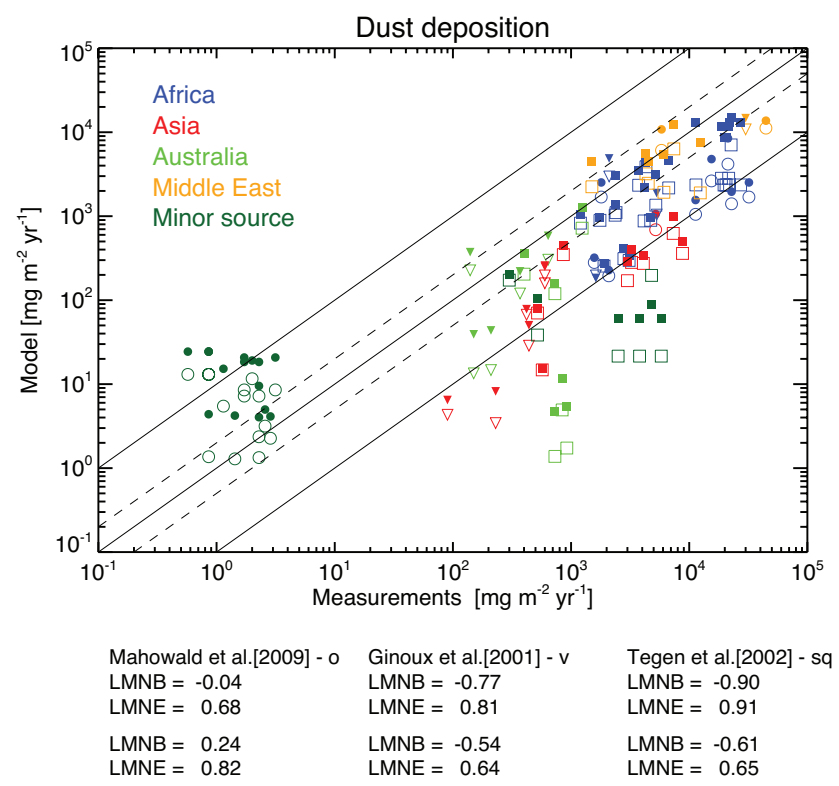

Figure 14. Scatter plot of annual-average dust deposition fluxes $\left(\mathrm{mg} \mathrm{m}^{-2} \mathrm{yr}^{-1}\right)$ simulated and observations obtained from Ginoux et al. (2001), Tegen et al. (2002) and Table S2 in Mahowald et al. (2009). Open symbols are for ModelE2-TOMAS and the filled symbol for ModelE2-OMA. LMNB and LMNE are presented below the plot: the first values are for ModelE2-TOMAS.

Figure 15 shows simulated annual-mean surface-layer EC and OM concentrations compared against the observations from the IMPROVE network and the European sites from Putaud et al. (2010). The simulated EC and OM in both models agree very well at the IMPROVE sites (for $\mathrm{EC}, \mathrm{LMNB}=-0.08$ to 0.05 ; for $\mathrm{OM}, \mathrm{LMNB}=-0.17$ to -0.08 ). Note that we applied an OM/OC ratio of 1.4 to the IMPROVE network to make it consistent with our model assumption, but the IMPROVE OM data provided to us were based on the ratio of 1.8. Over Europe, the model predictions are still reasonable (within a factor of 2-3), but the agreement is slightly worse than the IMPROVE sites. Since these sites are mostly adjacent to the source/emissions, the good agreement suggests that the emission inventory (used in this study) is well represented for these regions.

Figure 16 compares simulated annual-mean $\mathrm{PM}_{2.5}$ concentrations against the GBD data set. Note that ModelE2OMA includes nitrate mass in its $\mathrm{PM}_{2.5}$, and the nitrate contributes to $\mathrm{PM}_{2.5}$ rather significantly. The GBD data are classified/presented by a region listed in Fig. 16a and b. The aerosol models capture the observation quite well at most locations (overall LMNB is -0.08 to -0.03 and LMNE is 0.2 to 0.25 ), but both models show the worst agreement for Oceania regions $(\mathrm{LMNB} / \mathrm{LMNE}=0.4-0.58)$ and Latin America $(\mathrm{LMNB} / \mathrm{LMNE}=-0.33$ to -0.48$)$. The $\mathrm{PM}_{2.5}$ overprediction in Oceania is mainly due to too many fine mode sea-salt particles (the overall agreement in Oceania is little influenced by sulfate or dust particles). Note that the sea-salt comparison 
(a) EC: IMPROVE

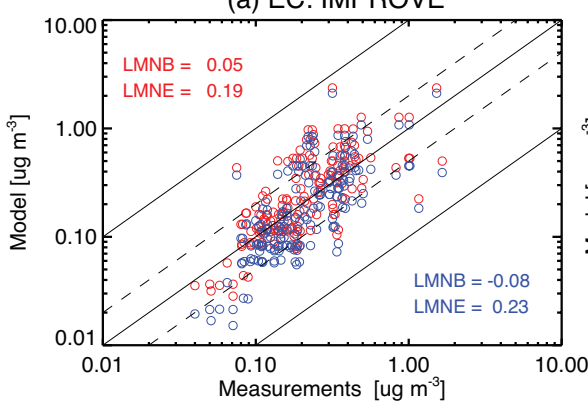

(c) EC: Europe

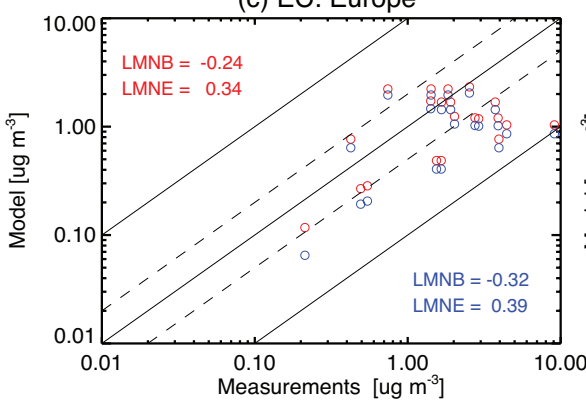

(b) OM: IMPROVE

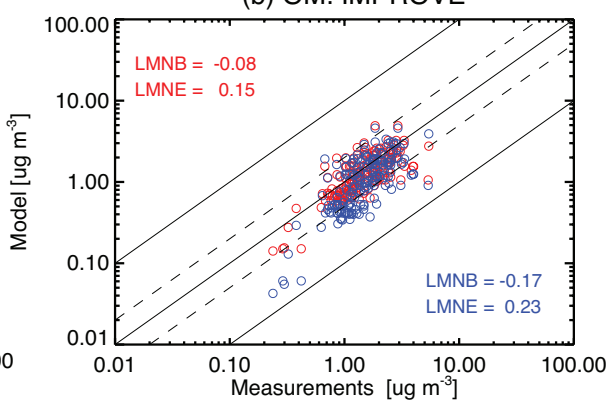

(d) OM: Europe

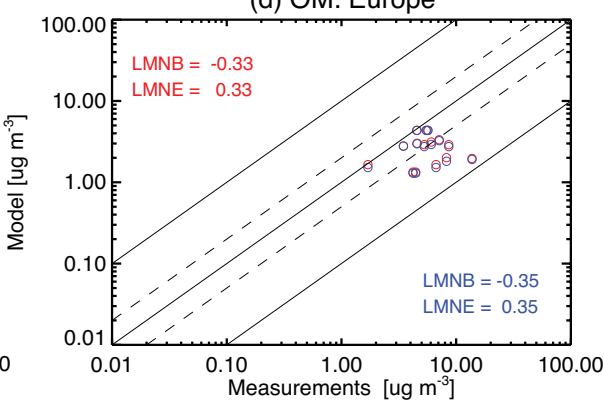

Figure 15. Scatter plots of annually averaged surface EC and OM mass concentrations $\left(\mu \mathrm{g} \mathrm{m}^{-3}\right)$ simulated (red for ModelE2-TOMAS and blue for ModelE2-OMA) and observations from the IMPROVE network (a and b) and the European sites from Putaud et al. (2010) (c and d).

(a) PM2.5 - ModelE2-TOMAS

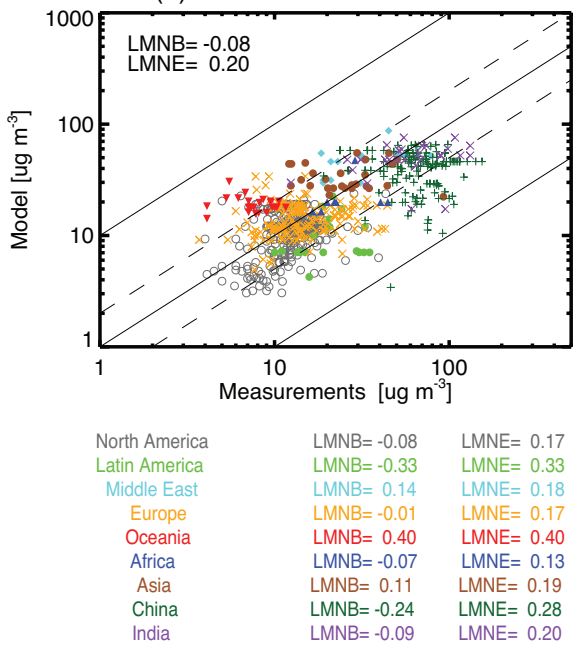

(b) PM2.5 - ModelE2-OMA
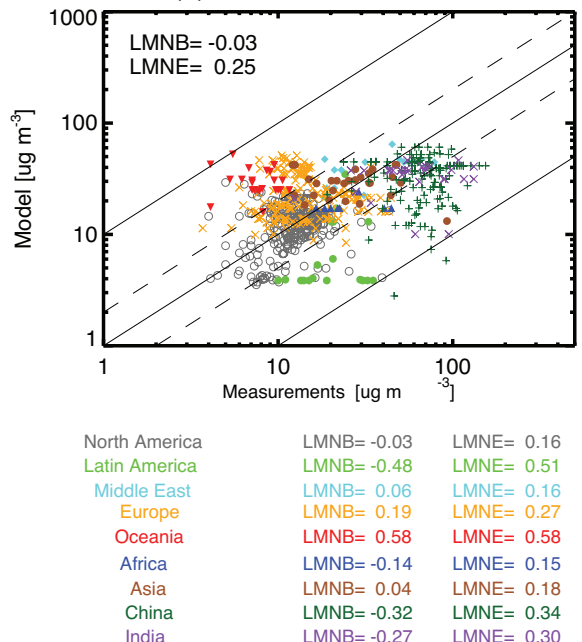

Figure 16. Scatter plots of annually averaged surface $\mathrm{PM}_{2.5}$ concentration $\left(\mu \mathrm{g} \mathrm{m}^{-3}\right)$ simulated and observations compiled by the Global Burden of Disease (GBD) study. ModelE2-TOMAS is shown in (a) and ModelE2-OMA in (b).

to the Miami data set (in Fig. 11) shows severe underpredictions at several sites in Oceania because their concentrations are likely dominanted by coarse mode sea-salt particles. The underprediction of $\mathrm{PM}_{2.5}$ in Latin America might be related to the biomass burning emissions. It is consistent with the AOD model being biased low over biomass burning source regions that is shown in Sect. 5.4. Model evaluation with the observed $\mathrm{PM}_{10}$ concentrations using the IMPROVE and European sites was also performed and is similar to the
$\mathrm{PM}_{2.5}$ evaluation results (not shown): LMNB and LMNE are -0.01 and 0.17 for ModelE2-TOMAS and 0.0 and 0.29 for ModelE2-OMA, respectively.

\subsection{Aerosol optical depth evaluation}

Simulated annual-mean clear-sky aerosol optical depths (AODs) at $550 \mathrm{~nm}$ are compared with observations from the Terra MODIS (MODerate resolution Image 

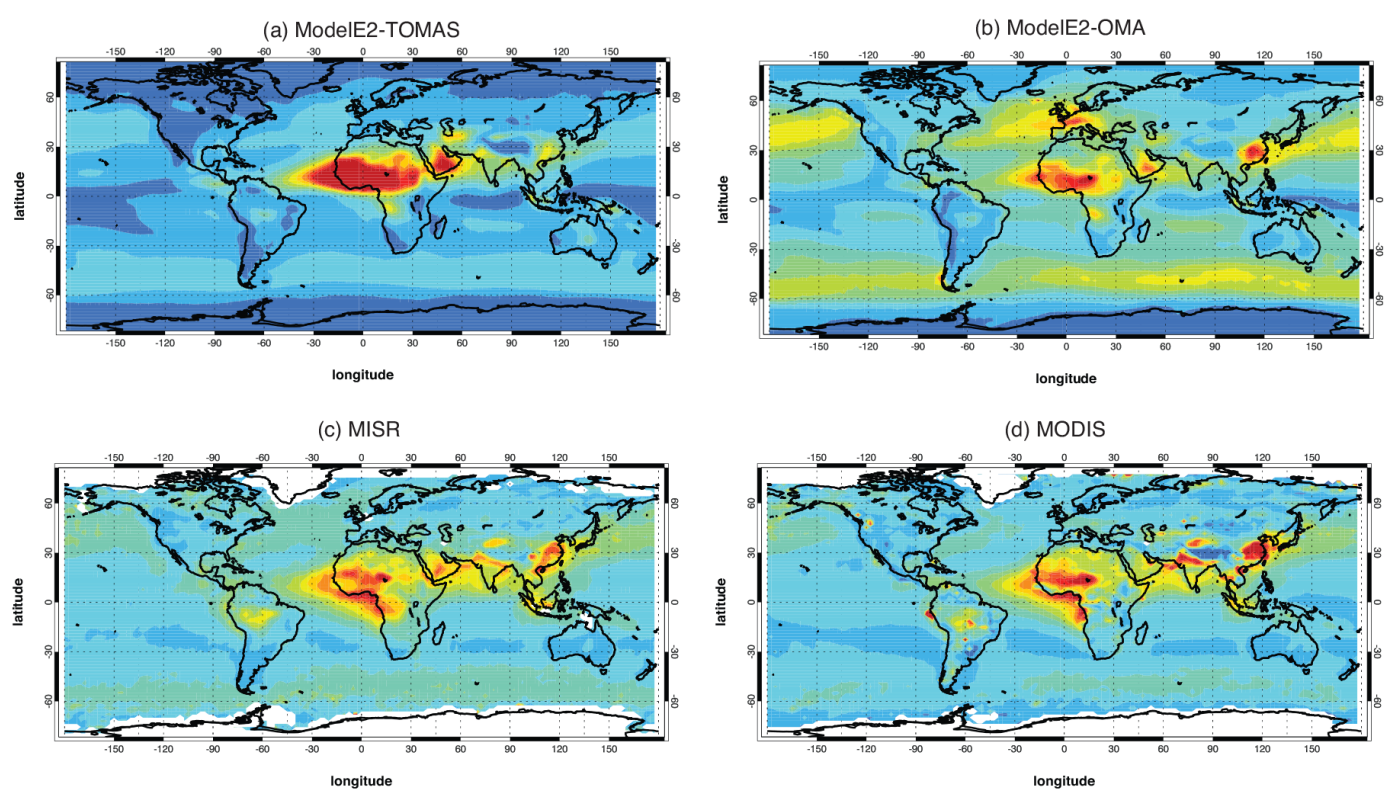

$\begin{array}{llllllllllllll}0.00 & 0.05 & 0.10 & 0.15 & 0.20 & 0.25 & 0.30 & 0.35 & 0.40 & 0.45 & 0.50 & 0.55 & 0.60\end{array}$

Figure 17. Global distributions of the annual-mean AOD from (a) ModelE2-TOMAS, (b) ModelE2-OMA, (c) MISR, and (d) MODIS. See Sect. 5.4 for the details of the MISR and MODIS AOD information.

Spectroradiometer; e.g. Abdou et al., 2005; Remer et al., 2008) and MISR (Multiangle Image SpectroRadiometer; e.g. Diner et al., 1998; Kahn et al., 2005) satellite instruments averaged over 2004-2006 (Fig. 17). Specifically, we use Terra MODIS Level 3 (MOD08_M3.051), Aqua MODIS Level 3 (MYD08_M3.051), and Terra MISR Level 3 (MIL3MAE4), which are monthly products with $1 \times 1$ degree resolution. We also use the Deep Blue AOD (e.g. Hsu et al., 2006) from Terra MODIS to increase its spatial coverage, and all the satellite data were obtained from http://disc.sci. gsfc.nasa.gov/giovanni. When the Deep Blue AOD and the "regular" AOD from Terra MODIS are both available, the former is used. However, we notice that the Deep Blue AOD shows some local hotspots (e.g. over South America) that are not shown in the "regular" MODIS AOD as well as the MISR AOD. Our model calculates clear-sky AOD by including only AOD values calculated at model locations where clouds are not present (i.e. cloud-free grid box only). The ModelE2TOMAS and ModelE2-OMA models capture the broad spatial features seen in the satellite measurements: (1) very high AODs over desert regions in and near northern Africa and the Arabian Peninsula associated with mineral dust, (2) the band of locally enhanced AOD over the Southern Ocean associated with sea salt, and (3) high AODs over East Asia and India due to high anthropogenic emissions. However, the models underestimate the AOD over East Asia and the IndoGangetic plain, especially compared to MODIS. Including nitrate in ModelE2-OMA, the AOD predictions increase, particularly over Europe and East Asia. Without nitrate, they become quite similar to the ModelE2-TOMAS AOD val- ues in the regions where the model nitrate predictions are significant. The models show an enhanced AOD over the biomass burning regions such as tropical South America, Africa and Indonesia, but it is clearly underestimated. The simulated AOD in North America and high-latitude regions appears also to be lower than the satellite observations. Comparing with ModelE2-OMA AOD, ModelE2-TOMAS shows a stronger AOD over Africa due to its higher dust burden and a lower AOD over the marine areas especially the Southern Ocean associated with sea salt.

We present spatial correlations and biases between the models and the satellite data (Table 6). For these analyses, the annual-mean satellite AOD fields are regridded to $2^{\circ} \times 2.5^{\circ}$ horizontal resolution, and the models are sampled only where the satellite AOD is available. Correlation coefficients between the model and satellite AODs are around 0.6-0.7 for ModelE2-TOMAS and around 0.4-0.5 for ModelE2-OMA. Given that the correlation coefficient between MODIS and MISR is 0.79 , the ModelE2-TOMAS model shows a good correlation with these satellite data. Both models show better correlations with MISR AOD. Compared to ModelE2-OMA, ModelE2-TOMAS shows a strong negative bias (about -29 to $-34 \%$ ) for both satellite data sets because of noticeably low AODs over the oceanic regions (where sea salt is dominant) shown in Fig. 16 and possibly because of a missing component such as nitrate aerosols, which contributes to AOD significantly over Europe and China in the ModelE2-OMA model. Over Europe, the ModelE2-OMA model overpredicts AOD due to nitrate though. Without nitrate in ModelE2-OMA, the normalized mean bias (NMB) 

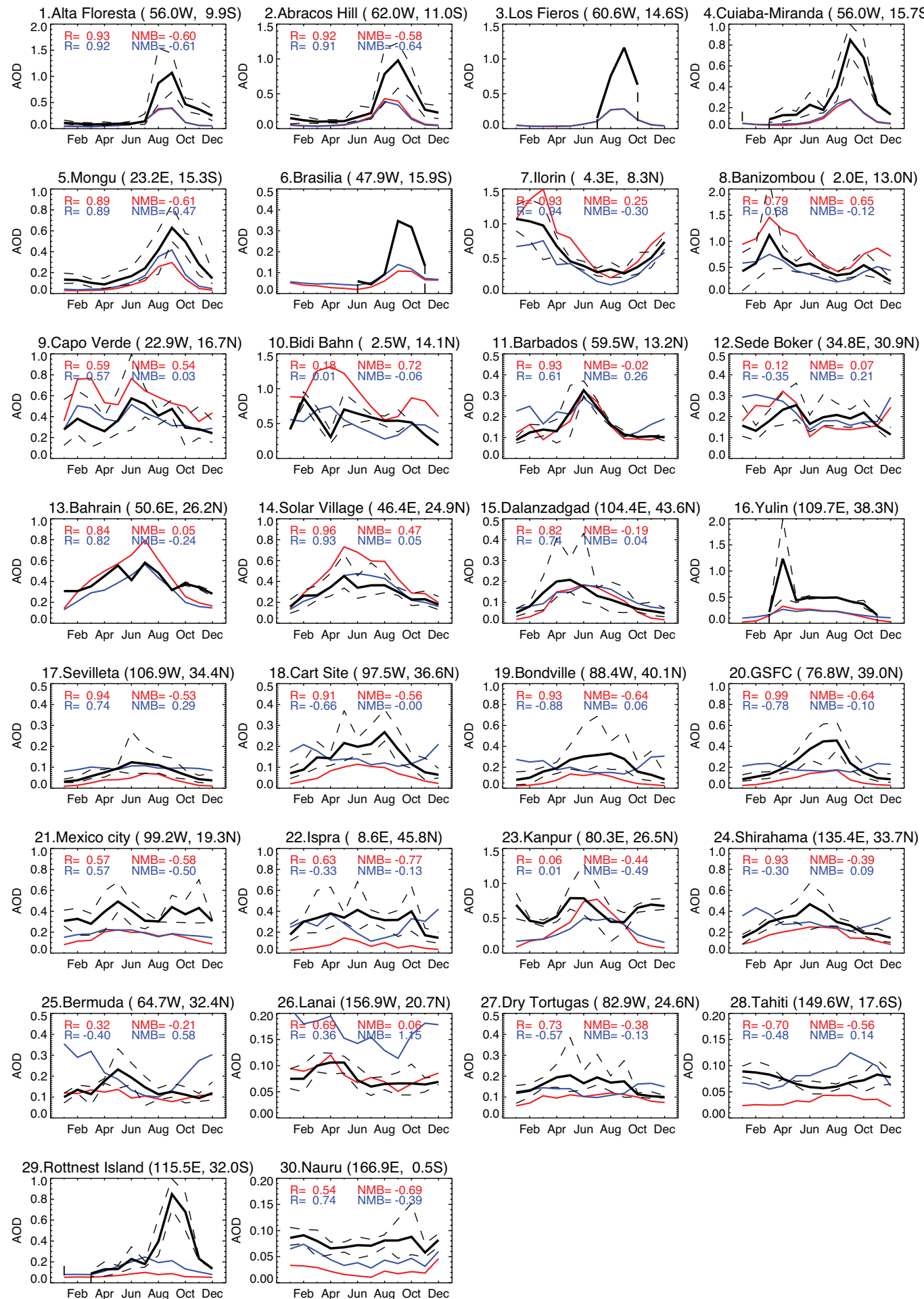

Figure 18. Comparisons of monthly averaged model AOD (red for ModelE2-TOMAS and blue for ModelE2-OMA) and AERONET AOD (black solid line). Correlation $(R)$ and normalized mean bias $(\mathrm{nmb})$ are provided only when the observation is available for 12 months.

falls from $8-16$ to -16 to $-21 \%$. Both models show lower AOD over China, India, and biomass burning regions, and a similar underprediction is shown by the ACCMIP mod- els (Shindell et al., 2013), indicating a possibility of aerosol emissions being underestimated in these regions.

Figure 18 presents simulated monthly mean AODs compared against AERONET (AErosol RObotic NETwork; 
Table 7. Locations of AERONET sites and corresponding measurement time periods.

\begin{tabular}{clccc}
\hline & Sites & Longitude & Latitude & Years \\
\hline 1 & Alta Floresta & $56.0^{\circ} \mathrm{W}$ & $9.9^{\circ} \mathrm{S}$ & $1999-2005$ \\
2 & Abracos Hill & $62.0^{\circ} \mathrm{W}$ & $11^{\circ} \mathrm{S}$ & $1999-2005$ \\
3 & Cuiaba-Miranda & $56.0^{\circ} \mathrm{W}$ & $15.7^{\circ} \mathrm{S}$ & $2001-2005$ \\
4 & Mongu & $23.2^{\circ} \mathrm{E}$ & $15.2^{\circ} \mathrm{S}$ & $1995-2005$ \\
5 & Ilorin & $4.3^{\circ} \mathrm{E}$ & $8.3^{\circ} \mathrm{N}$ & $1998-2005$ \\
6 & Banizombou & $2.0^{\circ} \mathrm{E}$ & $13.0^{\circ} \mathrm{N}$ & $1995-2005$ \\
7 & Capo Verde & $22.9^{\circ} \mathrm{W}$ & $16.7^{\circ} \mathrm{N}$ & $1994-2004$ \\
8 & Bidi Bahn & $2.5^{\circ} \mathrm{W}$ & $14.1^{\circ} \mathrm{N}$ & $1996-1997$ \\
9 & Barbados & $59.5^{\circ} \mathrm{W}$ & $13.2^{\circ} \mathrm{N}$ & $1996-2000$ \\
10 & Sede Boker & $34.8^{\circ} \mathrm{E}$ & $30.9^{\circ} \mathrm{N}$ & $1998-2005$ \\
11 & Bahrain & $50.6^{\circ} \mathrm{E}$ & $26.2^{\circ} \mathrm{N}$ & $2004-2005$ \\
12 & Solar Village & $46.4^{\circ} \mathrm{E}$ & $24.9^{\circ} \mathrm{N}$ & $1999-2005$ \\
13 & Dalanzadgad & $104.4^{\circ} \mathrm{E}$ & $43.6^{\circ} \mathrm{N}$ & $1997-2005$ \\
14 & Yulin & $109.7^{\circ} \mathrm{E}$ & $38.3^{\circ} \mathrm{N}$ & $2001-2002$ \\
15 & Sevilleta & $106.9^{\circ} \mathrm{W}$ & $34.4^{\circ} \mathrm{N}$ & $1994-2005$ \\
16 & Cart site & $97.5^{\circ} \mathrm{W}$ & $36.6^{\circ} \mathrm{N}$ & $1996-2005$ \\
17 & Bondville & $88.4^{\circ} \mathrm{W}$ & $40.1^{\circ} \mathrm{N}$ & $1996-2005$ \\
18 & GSFC & $76.8^{\circ} \mathrm{W}$ & $39.0^{\circ} \mathrm{N}$ & $1995-2005$ \\
19 & Mexico City & $99.2^{\circ} \mathrm{W}$ & $19.3^{\circ} \mathrm{N}$ & $1999-2005$ \\
20 & Ispra & $8.6^{\circ} \mathrm{E}$ & $45.8^{\circ} \mathrm{N}$ & $2001-2005$ \\
21 & Kanpur & $80.3^{\circ} \mathrm{E}$ & $26.5^{\circ} \mathrm{N}$ & $2001-2005$ \\
22 & Shirahama & $135.4^{\circ} \mathrm{E}$ & $33.7^{\circ} \mathrm{N}$ & $2000-2005$ \\
23 & Bermuda & $64.7^{\circ} \mathrm{W}$ & $32.4^{\circ} \mathrm{N}$ & $1996-2005$ \\
24 & Lanai & $156.9^{\circ} \mathrm{W}$ & $20.7^{\circ} \mathrm{N}$ & $1996-2004$ \\
25 & Dry Tortugas & $82.9^{\circ} \mathrm{W}$ & $24.6^{\circ} \mathrm{N}$ & $1996-2003$ \\
26 & Tahiti & $149.6^{\circ} \mathrm{W}$ & $17.6^{\circ} \mathrm{S}$ & $1999-2005$ \\
27 & Rottnest Island & $115.5^{\circ} \mathrm{E}$ & $32.0^{\circ} \mathrm{N}$ & $2001-2004$ \\
28 & Nauru & $166.9^{\circ} \mathrm{E}$ & $0.5^{\circ} \mathrm{S}$ & $1999-2005$ \\
\hline & & & & \\
\hline
\end{tabular}

Holben et al., 1998, 2001) measurements at 28 sites that represent the following characteristic regions: polluted continental, marine, biomass burning, and dusty regions (see Table 7 for individual site information). Both ModelE2TOMAS and ModelE2-OMA underestimate the maximum AOD during summer by a factor of 2-3 at the biomass burning sites ( 1 to 6 ), but capture the observed annual cycle quite well $(R>\sim 0.9)$. Unlike other biomass burning sites, simulated AODs at Ilorin and Banizoumbou are comparable to the observations possibly due to the influence of mineral dust. The agreement between the models and the AERONET AOD is generally good in the dusty regions (9 to 16). The ModelE2-TOMAS model shows a slight overprediction of AOD during spring at Capo Verde and Bidi Bahn, which are located near the African dust sources, although it shows a good agreement at Barbados where is also influenced by African dust.

For ModelE2-TOMAS, all polluted continental sites (17 to 24) show large underpredictions, while the model tends to capture the observed annual cycle well. However, the model surface aerosol mass concentrations agree well with the observations from IMPROVE network and several European sites (see Figs. 8, 10, 12, 15, and 16). This might be due to the fact that column AOD depends on many additional factors (e.g. optical properties and vertical distribution of aerosols) and provides a measure of total radiatively active aerosols in the atmosphere. Misrepresentation of these factors or missing a chemical component could introduce a bias in the model AODs. For ModelE2-OMA, the model AOD without nitrate is quite similar to the ModelE2-TOMAS AOD. Including nitrate in ModelE2-OMA, it simulates the annualmean AERONET AOD relatively well, but the observed annual cycle worse. Although the inclusion of nitrate is helpful for the underpredicted AOD in polluted regions, the overprediction of wintertime AOD suggests that the model nitrate is too large.

With the ModelE2-TOMAS model, the oceanic sites (25 to 30) are generally underpredicted roughly by a factor of 2, except for Bermuda (25) and Lanai (26). By contrast, the ModelE2-OMA model captures the observed magnitude relatively well, but overpredicts at Bermuda and Lanai. Note that Bermuda (23) and Rottnest Island (27) are influenced by long-range transported mineral dust. The ModelE2-OMA model predicts AOD that is more comparable to observations at these oceanic sites than ModelE2-TOMAS. Compared to ModelE2-OMA, the underprediction of sea-salt concentrations at the remote sites (shown in Figs. 10 and 11 in Sect. 5.3) and the underpredictions of AODs at the remote oceanic sites in ModelE2-TOMAS may be due to a faster sea-salt removal rate (see the global budgets in Table 4 for the details). It is worth mentioning that the inclusion of marine organic aerosols, which are not included in this paper, may not increase AOD noticeably at remote oceanic sites. Using the same host model, Tsigaridis et al. (2013) show that Southern Ocean AOD is quite insensitive to the inclusion of marine organic particles, but is strongly sensitive to the sea-salt emission parameterization (see Fig. 9 of Tsigaridis et al., 2013).

\subsection{Aerosol number budgets and its distributions}

This section includes only ModelE2-TOMAS results, as ModelE2-OMA does not predict aerosol number concentrations. Global mean number budgets for all three simulations, including two sensitivity runs for nucleation rates, are presented in Table 8 (see Sect. 4.2 and Table 1 for the details of run descriptions). Compared to the BASE run, global mean $\mathrm{CN}_{3}$ (particles with dry diameters larger than $3 \mathrm{~nm}$ ), $\mathrm{CN}_{10}$ (particles with dry diameters larger than $10 \mathrm{~nm}$ ), and $\mathrm{CN}_{100}$ (particles with dry diameters larger than $100 \mathrm{~nm}$ ) concentrations in the LowNUC run are decreased by 74,33 , and $7 \%$ in the troposphere and 29,17 , and $3 \%$ in the lowermost layer, respectively. The smaller impact on $\mathrm{CN}$ in the lowermost layer is due to the presence of the primary emissions near the surface. It is also because the binary nucleation parameterization used in this model produces few particles in the boundary layer; however, nucleated particles in the up- 
Table 8. Summary of the global annual average of tropospheric and surface-layer aerosol number budgets including $\mathrm{J}_{3}$ (new particle formation rates at $3 \mathrm{~nm}$ ), $\mathrm{CN}_{3}$ (number concentration of particles with $\mathrm{Dp} \geq 3 \mathrm{~nm}$ ), $\mathrm{CN}_{10}(\mathrm{Dp} \geq 10 \mathrm{~nm})$, and $\mathrm{CN}_{100}(\mathrm{Dp} \geq 100 \mathrm{~nm})$ in ModelE2TOMAS. Values normalized by tropospheric volume at $273 \mathrm{~K}$ and $1 \mathrm{~atm}$.

\begin{tabular}{lcccccccc}
\hline & $\begin{array}{c}\text { Emission rate } \\
\left(\mathrm{cm}^{-3} \mathrm{~s}^{-1}\right)\end{array}$ & $\begin{array}{c}\text { Tropospheric } \mathrm{J}_{3} \\
\left(\mathrm{~cm}^{-3} \mathrm{~s}^{-1}\right)\end{array}$ & $\begin{array}{c}\text { Tropospheric } \\
\mathrm{CN}_{3}\left(\mathrm{~cm}^{-3}\right)\end{array}$ & $\begin{array}{c}\text { Tropospheric } \\
\mathrm{CN}_{10}\left(\mathrm{~cm}^{-3}\right)\end{array}$ & $\begin{array}{c}\text { Tropospheric } \\
\mathrm{CN}_{100}\left(\mathrm{~cm}^{-3}\right)\end{array}$ & $\begin{array}{c}\text { Surface-layer } \\
\mathrm{CN}_{3}\left(\mathrm{~cm}^{-3}\right)\end{array}$ & $\begin{array}{c}\text { Surface-layer } \\
\mathrm{CN}_{10}\left(\mathrm{~cm}^{-3}\right)\end{array}$ & $\begin{array}{c}\text { Surface-layer } \\
\mathrm{CN}_{100}\left(\mathrm{~cm}^{-3}\right)\end{array}$ \\
\hline Base & $5.47 \times 10^{-4}$ & 0.131 & 4852 & 939 & 211 & 1622 & 1331 & 416 \\
LowNUC & $5.47 \times 10^{-4}$ & 0.013 & 1277 & 628 & 197 & 1152 & 1111 \\
NoNUC & $5.47 \times 10^{-4}$ & 0.000 & 222 & 221 & 159 & 935 & 919 & 305 \\
\hline
\end{tabular}

per/free troposphere may be carried down to the surface and influence $\mathrm{CN}$ there. Since the LowNUC run produces fewer nucleated particles than the BASE run, each nucleated particle is more likely to grow more efficiently to form $\mathrm{CCN}$ sized particles, as there is less competition for sulfuric acid and condensable organics. We can see this using the number budgets in Table 8. The increase in $\mathrm{CN}_{70}$ with the BASE case nucleation (i.e. BASE $\mathrm{CN}_{70}-\mathrm{NONUC} \mathrm{CN}_{70}$ ) is $51 \mathrm{~cm}^{-3}$ for the nucleation rate $(\mathrm{J} 3)$ of $0.131 \mathrm{~cm}^{-3} \mathrm{~s}^{-1}$ and that with the LowNUC case nucleation, $37 \mathrm{~cm}^{-3}$ for $\mathrm{J} 3$ of $0.013 \mathrm{~cm}^{-3} \mathrm{~s}^{-1}$. In the BASE run, $\mathrm{J} 3$ is 10 times higher, but the $\mathrm{CN}_{70}$ increase by nucleation is only $\sim 1.4$ times higher than those in the LowNUC run.

Aerosol number burdens normalized by tropospheric volume are dramatically reduced when nucleation is turned off in the NoNUC run. For example, global mean $\mathrm{CN}_{3}$ and $\mathrm{CN}_{10}$ are decreased by 95 and $76 \%$ in the troposphere and by 42 and $31 \%$ in the surface layer. We found that $24 \%$ of tropospheric $\mathrm{CCN}$-sized particles (i.e. $\mathrm{CN}_{100}$ ) and $\sim 10 \%$ of surface-layer $\mathrm{CCN}$-sized particles result from binary nucleation in our model; the contribution of the nucleated particles to the $\mathrm{CCN}$ concentrations is larger as the cutoff size (e.g. $100 \mathrm{~nm}$ in $\mathrm{CN}_{100}$ ) gets lower.

Figure 19 shows global distributions of annually averaged $\mathrm{CN}_{3}, \mathrm{CN}_{10}$, and $\mathrm{CN}_{100}$ in the lowermost layer for the BASE, LowNUC, and NoNUC runs, and Fig. 20 presents their zonal distributions. For the $\mathrm{CN}_{3}$ distributions, the BASE run shows a high concentration (over $5000 \mathrm{~cm}^{-3}$ ) in the upper/free troposphere and the entire Antarctica troposphere due to nucleation and over polluted continental regions due to the primary emissions (see Figs. 19a and 20a). Note that the $\mathrm{CN}_{3}$ near the surface in Antarctica comes from nucleated particles from the upper/free troposphere, as the binary parameterization does not predict nucleation in the boundary layer. $\mathrm{CN}_{3}$ in the LowNUC run (Figs. 19d and 20d) is decreased significantly in the free troposphere and in the surface layer over Eurasia and western Antarctica (fewer nucleated particles formed above subside to the surface). When nucleation is switched off, $\mathrm{CN}_{3}$ is very close to $\mathrm{CN}_{10}$ near to the surface (Figs. 19g and h) because nucleation contributes most $\mathrm{CN}$ between 3 to $10 \mathrm{~nm}$. For $\mathrm{CN}_{10}$, its spatial pattern over the continents is quite similar among the runs as it is mostly driven by primary emissions except for some locations heavily influenced by the nucleated particles formed in the up- per/free troposphere (Fig. 19b, e and h and Fig. 20b, e, h). A pronounced difference in $\mathrm{CN}_{10}$ is shown over oceans, indicating a larger contribution of nucleated particles to $\mathrm{CN}_{10}$ in these regions. This is consistent with Merikanto et al. (2009), which shows a higher contribution of nucleation to $\mathrm{CN}$ over oceanic regions. $\mathrm{CN}_{100}$ differs little among runs except for SH high latitudes where binary nucleation plays an important role (Fig. 19c, f, and i). This is consistent with Pierce and Adams (2009a, b) showing that the exhibited high SH latitude region for the most positive changes in $\mathrm{CCN}(0.2 \%)$ by turning on binary nucleation and, again, with Merikanto et al. (2009) showing $65 \%$ of $\mathrm{CCN}(0.2 \%)$ in Antarctica resulted from upper tropospheric nucleation. $\mathrm{CN}_{100}$ shows a maximum at 10 to $40^{\circ} \mathrm{N}$ because most anthropogenic primary emissions are located in mid-NH latitudes. Rather surprisingly, dust particles in our model contribute to $\mathrm{CN}_{100}$ quite significantly over the source regions. This is opposite to the results from GISS-TOMAS (Lee et al., 2009), which shows a $10-20 \%$ reduction in $\mathrm{CCN}(0.2 \%)$ when introducing mineral dust emissions. Despite the direct source of $\mathrm{CCN}-$ sized particles from dust emissions, $\mathrm{CCN}$ and ultrafine particles that grow to become $\mathrm{CCN}$ are scavenged via coagulation with coarse dust particles, and dust particles compete for condensable sulfuric acid, leading to a slower growth rate of ultrafine particles.

\subsection{Aerosol number evaluation}

The CN measurement data set compiled by Spracklen et al. (2010) is used to evaluate simulated annual-mean CN concentrations (in Fig. 21) and monthly mean $\mathrm{CN}$ concentrations (in Fig. 22). Details of the measurement procedures for each site, including the instrument type and minimum cutoff diameter (varying from 3 to $14 \mathrm{~nm}$ ), can be found in Table 2 of Spracklen et al. (2010). Due to an incomplete annual cycle, we excluded Mt. Waliguan, Finokalia, Listvyanka, and Weybourne. The measurement sites are classified into three categories: FT (free troposphere; 1 to 8 in Fig. 22), MBL (marine boundary layer; 9 to 15 in in Fig. 22), and CBL (continental boundary layer; 16 to 32 in Fig. 22). We sampled the model values to match the altitude of each measurement site except for the free troposphere sites that use an altitude $30 \%$ lower because it improved the annual cycles prediction significantly. Previous studies pointed out that free tro- 
(a) BASE: CN3

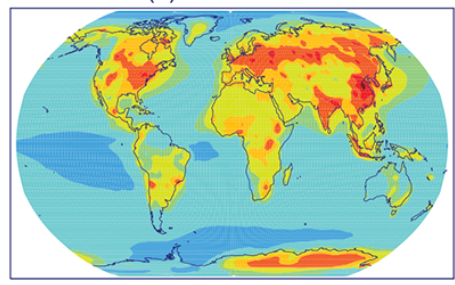

(d) LowNUC: CN3

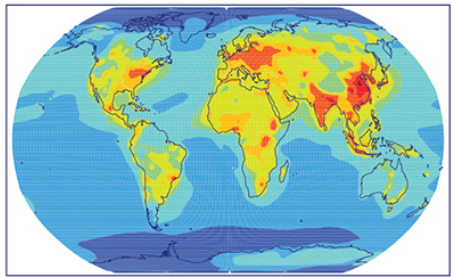

(g) NoNUC: CN3

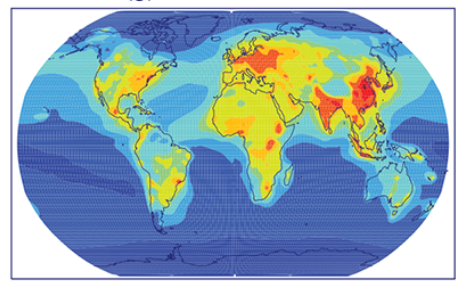

(b) BASE: CN10

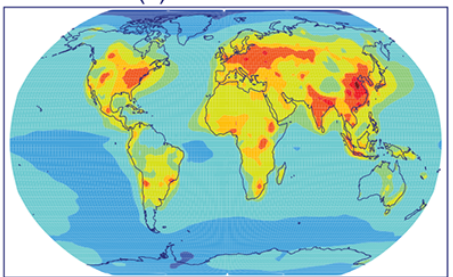

(e) LowNUC: CN10

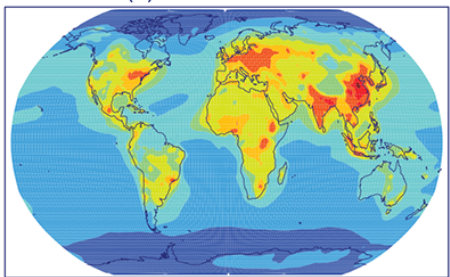

(h) NoNUC: $\mathrm{CN} 10$

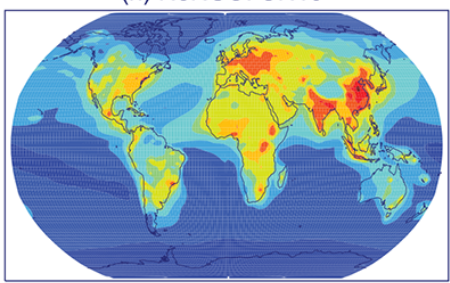

(c) BASE: CN100

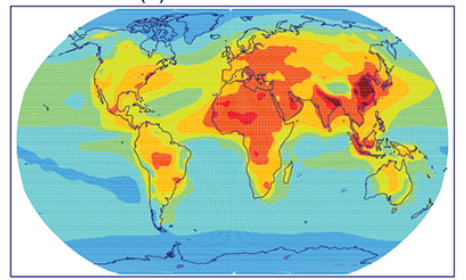

(f) LowNUC: CN100

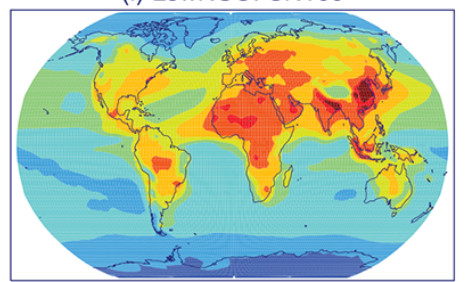

(i) NoNUC: CN100

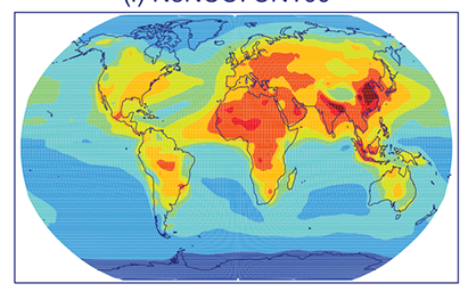

\begin{tabular}{|c|c|c|c|c|c|c|c|c|c|c|c|}
\hline \multicolumn{12}{|c|}{ CN3/CN10 } \\
\hline 0. & 10. & 100. & 300. & 500. & 1000. & 1500. & 3000. & 5000. & 10000. & 15000. & $\begin{array}{c}30000 \\
{\left[\mathrm{~cm}^{-3}\right]}\end{array}$ \\
\hline \multicolumn{12}{|c|}{ CN100 } \\
\hline 0.0 & 1.0 & 10.0 & 30.0 & 100.0 & 200.0 & 300.0 & 500.0 & 1000.0 & 2000.0 & 3000.0 & 50000 \\
\hline
\end{tabular}

Figure 19. Annually averaged $\mathrm{CN}_{3}(\mathrm{Dp} \geq 3 \mathrm{~nm}), \mathrm{CN}_{10}(\mathrm{Dp} \geq 10 \mathrm{~nm})$, and $\mathrm{CN}_{100}(\mathrm{Dp} \geq 100 \mathrm{~nm})$ concentrations in the lowermost layer for the BASE run (a to $\mathbf{c}$ ), the LowNUC run (d to $\mathbf{f})$, and the NoNUC run (g to i) of ModelE2-TOMAS. Units $\operatorname{are~}^{-3}$.

pospheric sites can be influenced by upslope winds that carry the planetary boundary layer air, so it cannot be assumed to be in the free troposphere all the time (e.g. Baltensperger, 1997; Collaud Coen et al., 2011). Our model does not seem to simulate this well, so sampling the model predictions at lower altitude (i.e. $30 \%$ lower) helps to increase the influence of PBL air. In Fig. 21, a whisker plot is used to present the three run results; the maximum of the whisker line for the BASE run; the circle symbol in the middle of the whisker line for the LowNUC run; the minimum for the NoNUC run.

On average, the annual-mean $\mathrm{CN}$ concentrations in the model agree with the observations well for the all three categories $(\mathrm{LMNB}=-0.26$ to 0.16 ; $\mathrm{LMNE}=0.13$ to 0.22 ; see Fig. 21), although the LowNUC simulation shows the best agreement to observation. Simulated annual cycles at individual sites also show that the model captures the measured magnitude reasonably, but overpredicts the $\mathrm{CN}$ during winter (November to March) that is worse at the CBL sites and results in poor seasonality (especially in the BASE run). The poor seasonality in ModelE2-TOMAS in all three runs sug- gests that other factors may play a role such as missing seasonal variation in primary emissions or scavenging that causes the poor seasonality rather than nucleation. The evaluation of $\mathrm{CN}$ at the South Pole shows that the model predicts too strong nucleation throughout the year.

Figure 23 compares the observed size distributions at six European sites during winter (DJF: December to February; Fig. 23a to f) and summer (JJA: June to August; Fig. 23d to 1) to the model. The observed size distributions are averaged during morning, afternoon, and night, while the model results are not broken into the three periods. These data are obtained from Putaud (2003) and, for the same sites shown in Fig. 21, the temporal coverage used in Putaud (2003) is not necessarily matched with them. Most sites are reasonably close to the data set used in Fig. 21. However, for the Jungfraujoch, the total $\mathrm{CN}$ concentrations summed from the size distribution data, which covers from June 1997 to May 1998, is about a factor of 2 lower than the $\mathrm{CN}$ shown in Fig. 21, which covers from 1995 to 1999 and from 2003 to 2007. As expected, the simulated size distributions of the model sim- 
(a) BASE: CN3

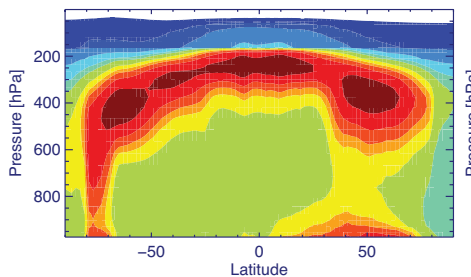

(d) LowNUC: CN3

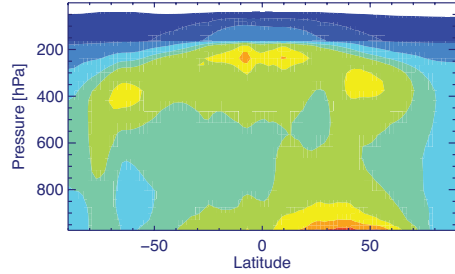

(g) NoNUC: CN3

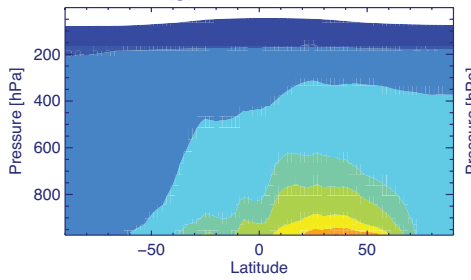

$\mathrm{CN} 3$ (b) BASE: CN10

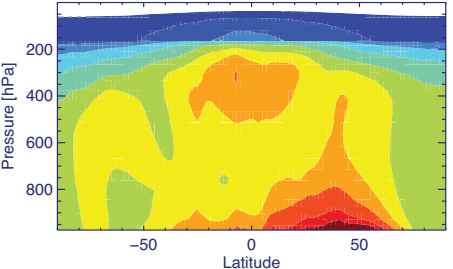

(e) LowNUC: CN10

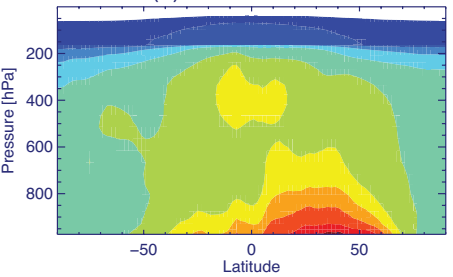

(h) NoNUC: CN10

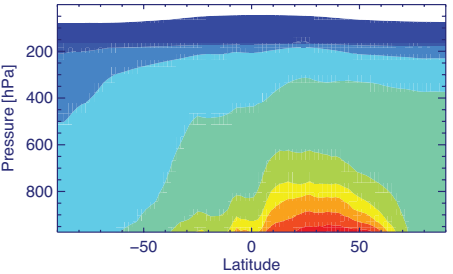

(c) BASE: CN100

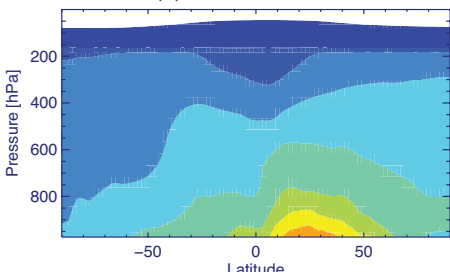

(f) LowNUC: CN100

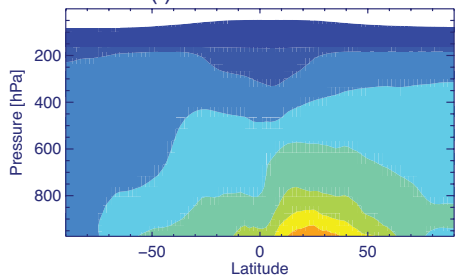

(i) NoNUC: CN100

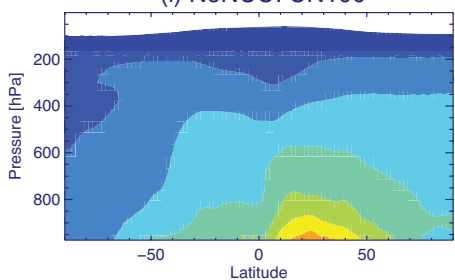

$\mathrm{CN} 10$ and $\mathrm{CN} 100$
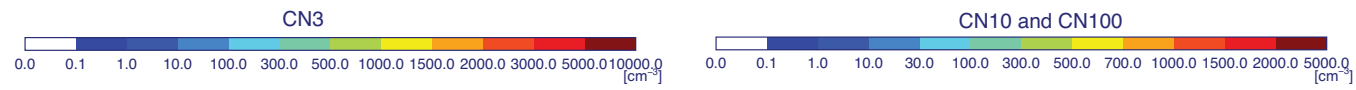

Figure 20. Annually and zonally averaged $\mathrm{CN}_{3}(\mathrm{Dp} \geq 3 \mathrm{~nm}), \mathrm{CN}_{10}(\mathrm{Dp} \geq 10 \mathrm{~nm})$, and $\mathrm{CN}_{100}(\mathrm{Dp} \geq 100 \mathrm{~nm})$ concentrations for the $\mathrm{BASE}$ run (a to $\mathbf{c})$, the LowNUC run (d to $\mathbf{f})$, and the NoNUC run (g to i) of ModelE2-TOMAS. Units are $\mathrm{cm}^{-3}$.

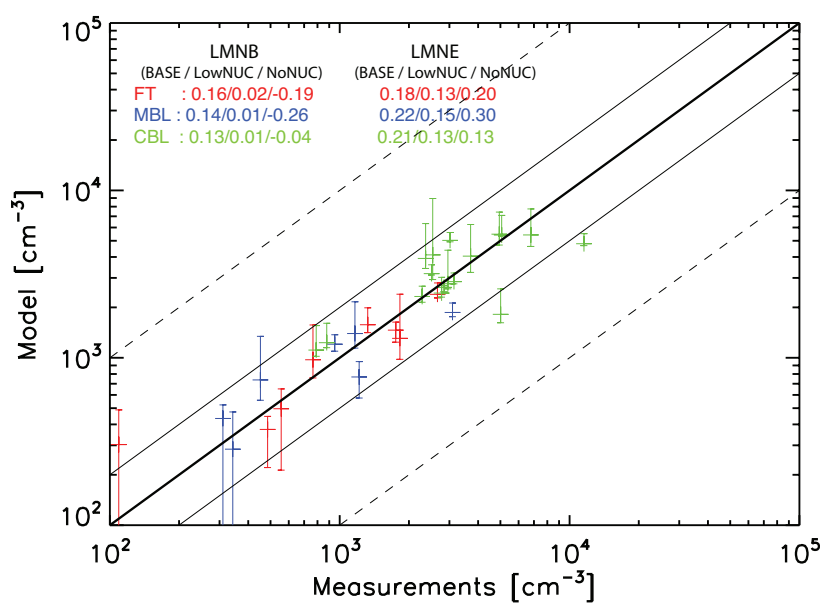

Figure 21. Scatter plot of simulated annual-mean aerosol number concentrations in comparison with a data set of surface number concentrations measurements at 36 sites around the world compiled by Spracklen et al. (2010). The top horizontal bar represents the BASE results, and the middle bar the LowNUC results and the lower bar the NoNUC results. Red color is for free troposphere (FT); blue for marine boundary layer (MBL); green for continental boundary layer (CBL). ulations differ according to what nucleation scheme is used. The impact of nucleation is more notable for particles smaller than $\sim 50 \mathrm{~nm}$, as expected, and also during winter. In general, the higher nucleation rates tend to overpredict Aitken model particles at most sites. For Harwell (Fig. 23c and i), particles below $50 \mathrm{~nm}$ are overpredicted even without nucleation. For the summer season, the model shows less sensitivity to nucleation rates and has better skill at capturing the observed size distributions.

The observed $\mathrm{CN}_{5}, \mathrm{CN}_{15}$, and $\mathrm{CN}_{120}$ concentrations from the LACE campaign (Petzold et al., 2002) are compared with three model runs (Fig. 24a to c). Below 700-800 mbar, all three model runs predict concentrations roughly within the observed $\mathrm{CN}_{5}, \mathrm{CN}_{15}$, and $\mathrm{CN}_{120}$ ranges. Above 700 800 mbar, the BASE simulation overpredicts $\mathrm{CN}_{5}$ and $\mathrm{CN}_{15}$ by approximately an order of magnitude and 2-3 times, respectively. For the NoNUC simulation, it captures the lower side of the observed $\mathrm{CN}_{15}$, but fails to capture the increasing $\mathrm{CN}_{5}$ concentrations with height above 600 mbar. All model runs basically show almost identical $\mathrm{CN}_{120}$ concentrations, and fall on the lower edge of the observed range.

We compare $\mathrm{CN}_{3}$ vertical profile measurements averaged into the three latitude bands over the Pacific Ocean (Clarke and Kapustin, 2002) with the model (Fig. $24 \mathrm{~d}$ to f). The 

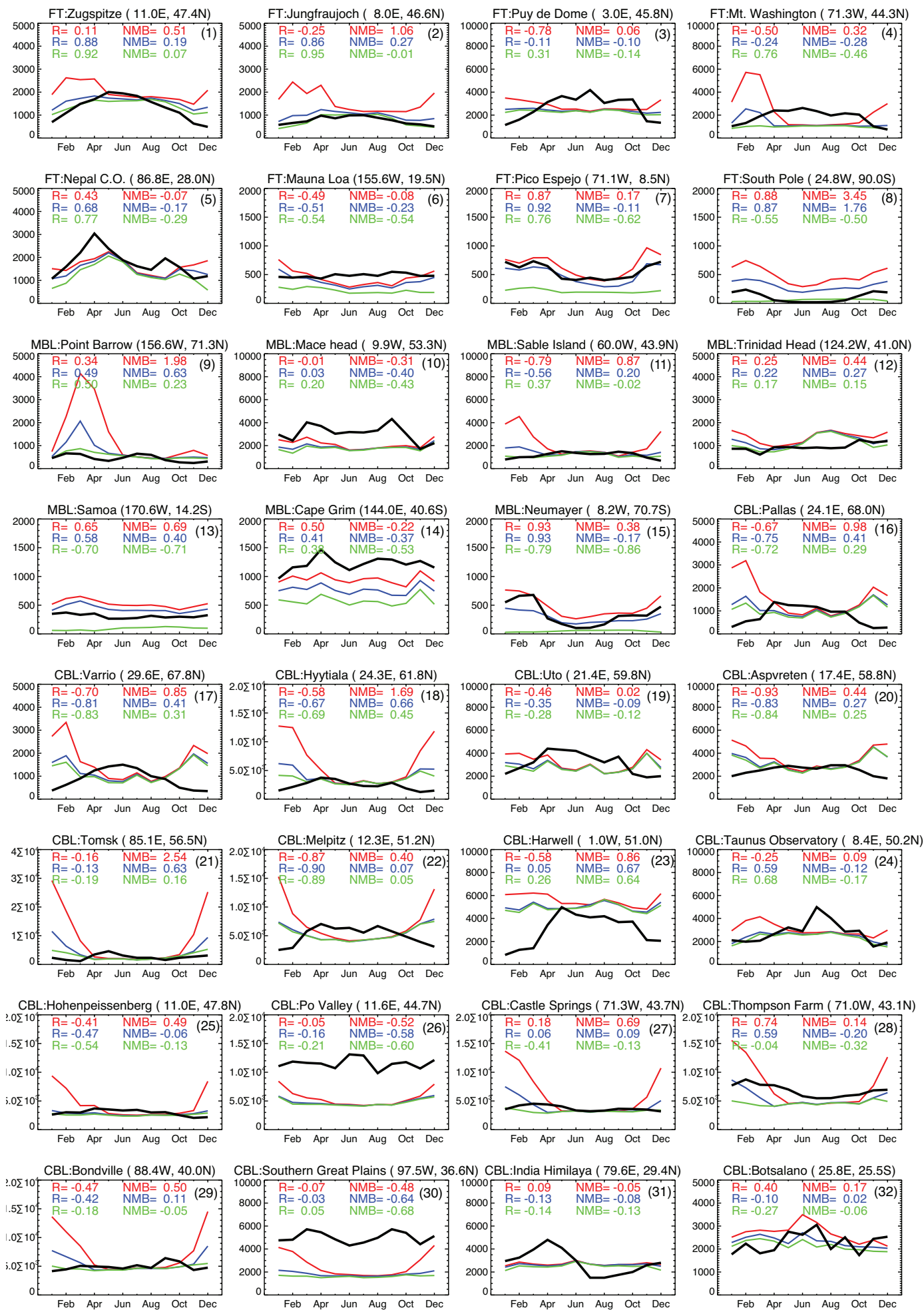

Figure 22. Annual cycle of aerosol number concentrations $\left(\mathrm{cm}^{-3}\right.$ at ambient conditions) at 32 sites. The observations are shown in black, and three model results are presented: red for BASE, blue for LowNUC, and green for NoNUC. The free tropospheric (FT) sites are from 1 to 8; the marine boundary layer (MBL) sites, 9 to 15 ; and the continental boundary layer (CBL) sites, 16 to 32. Correlation $(R)$ and normalized mean bias (NMB) are provided only when the observation is available for 12 months. 

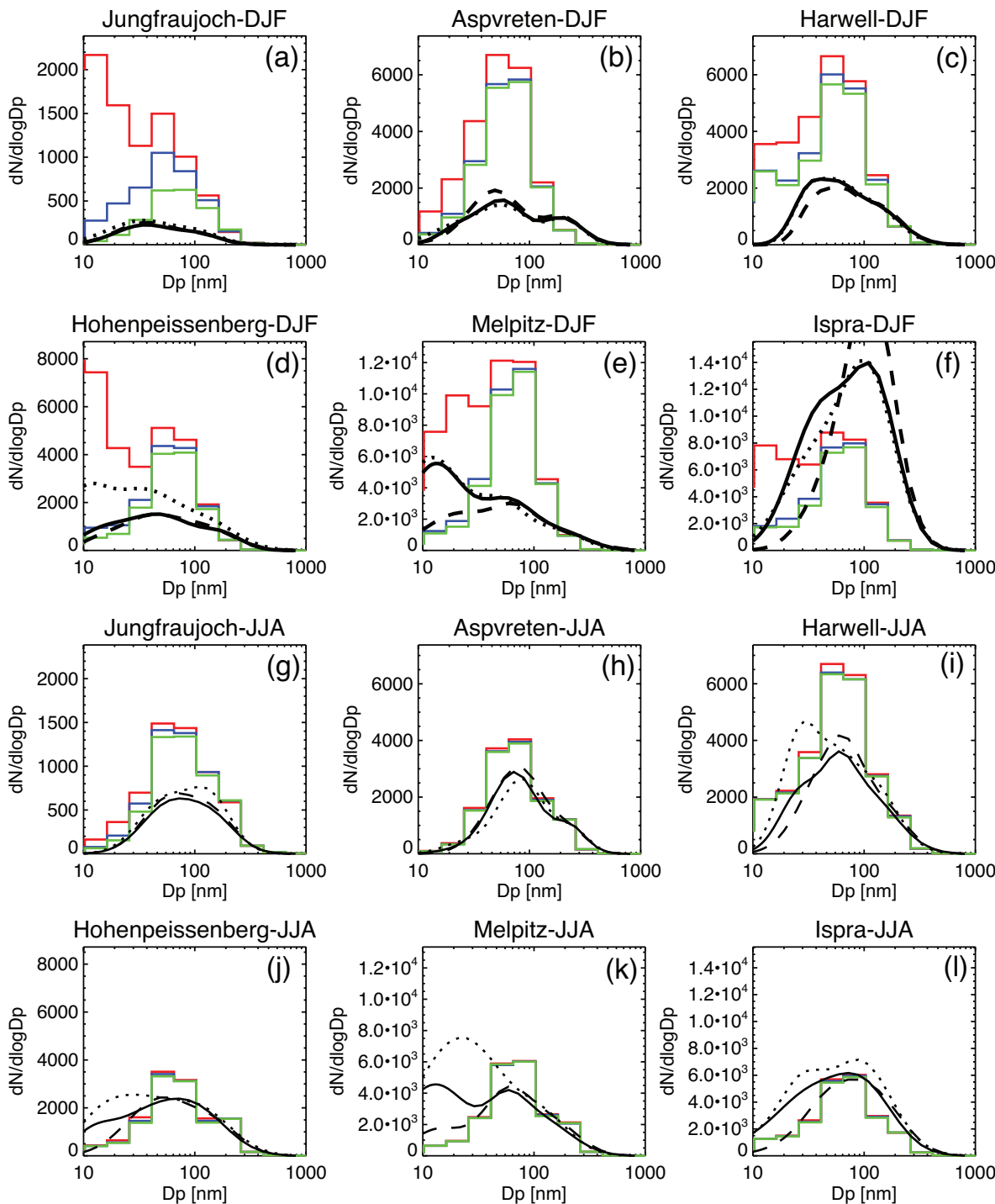

Figure 23. Number size distributions from European sites during winter (DJF; a to f) and summer (JJA; $\mathbf{g}$ to I) that are obtained from lognormal three-mode fits during morning (black solid), afternoon (black dotted), and night (black dashed). The model results are the seasonal mean, shown in red lines for the BASE run, blue lines for the LowNUC run, and green lines for the NoNUC run.

simulated $\mathrm{CN}_{3}$ profiles in LowNUC agree well with the observation, capturing the increasing $\mathrm{CN}_{3}$ with height. Although the BASE run shows the increasing pattern correctly, it overpredicts $\mathrm{CN}_{3}$ severely above approximately $6 \mathrm{~km}$. The NoNUC run disagrees with the observations for all latitudes and altitudes and clearly fails to reproduce the high number concentrations in the upper troposphere that result from nucleation.

The observed Aitken mode and accumulation mode concentrations and size distributions in the marine boundary layer (Heintzenberg et al., 2000) are compared with the model in Figs. 25 and 26. The measurements are aggregated into $15^{\circ}$ latitude ranges. For the Aitken mode (Fig. 25a), the LowNUC run shows the closest agreement to observations.
However, whereas the observations show higher concentrations in the $\mathrm{SH}$ than in the $\mathrm{NH}$, all model simulations show the opposite tendency. Similarly, other global models with binary nucleation show underpredicted $\mathrm{CN}$ concentrations in the $\mathrm{SH}$ and either well-simulated or overpredicted $\mathrm{CN}$ in the NH (e.g. Easter et al., 2004; Spracklen et al., 2005; Pierce and Adams, 2006; Pierce et al., 2007; Trivitayanurak et al., 2008; Mann et al., 2010; Wang et al., 2011). For the accumulation mode (Fig. 25b), the three model runs are quite similar to each other and are within the observed range.

In Fig. 26, ModelE2-TOMAS captures the bimodal size distribution shown in the observations reasonably, which is mainly determined by the activation diameter assumed in wet deposition (and cloud processing): $\sim 80 \mathrm{~nm}$ as an ac- 
(a) CN5

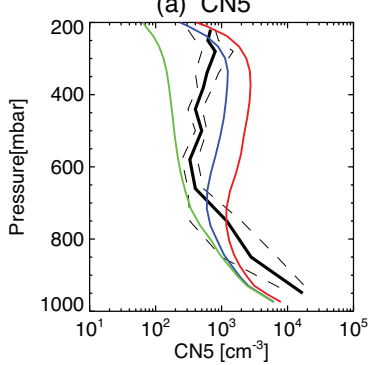

LACE campaign

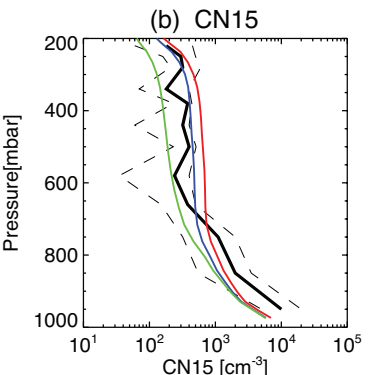

(c) $\mathrm{CN} 120$

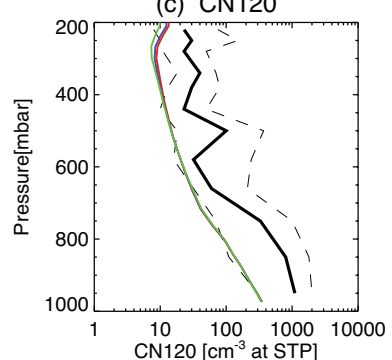

CN3 from Clarke and Kapustin (2002)
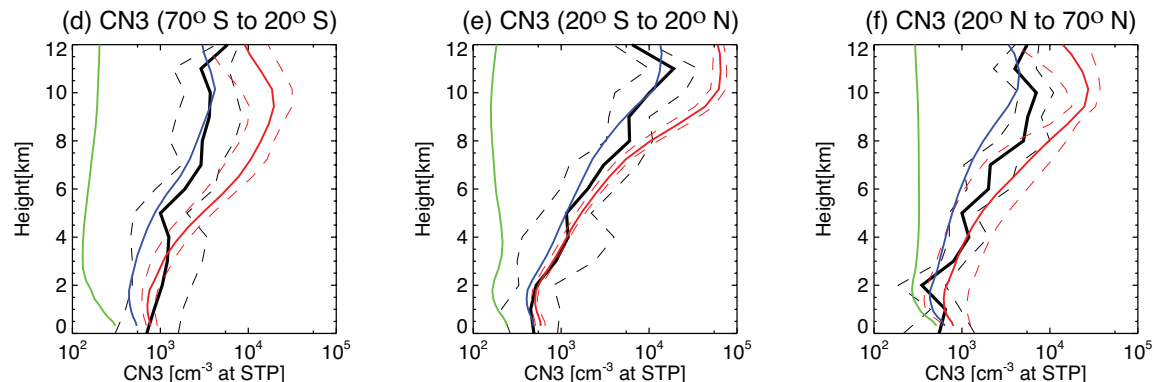

Figure 24. Vertical profiles of aerosol number concentrations from the observations (black lines) and ModelE2-TOMAS (red lines for the BASE run, blue lines for the LowNUC run, and green lines for the NoNUC run). The $\mathrm{CN}_{5}, \mathrm{CN}_{15}, \mathrm{CN}_{120}$ concentrations (ambient conditions) from the LACE campaign (Petzold et al., 2002, in northeastern Germany) are shown in a to c, respectively. The observed $\mathrm{CN}_{3}$ concentrations (STP conditions: $1 \mathrm{~atm}, 273 \mathrm{~K}$ ) over the Pacific Ocean, which are averaged into the 3 latitude bands $\left(70\right.$ to $20^{\circ} \mathrm{S}, 20^{\circ} \mathrm{S}$ to $20^{\circ} \mathrm{N}$, and 20 to $70^{\circ} \mathrm{N}$; Clarke and Kapustin, 2002), are shown in $\mathbf{d}$ to f. The dashed lines show the standard deviation for the observations and the min/max monthly mean for the model (only in $\mathbf{d}$ to $\mathbf{f}$ ).

(a) Aitken mode

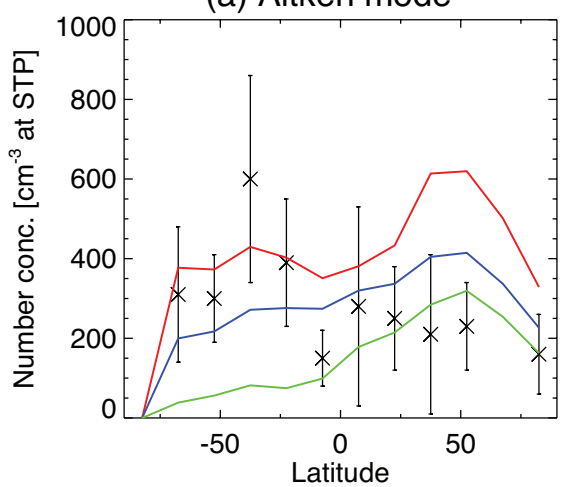

(b) Accumulation mode

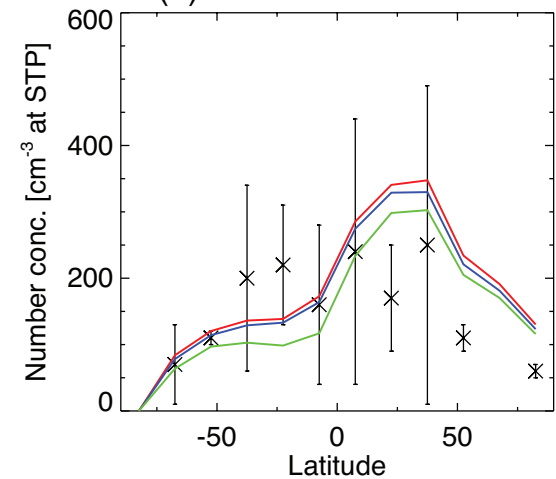

Figure 25. Simulated number concentrations in (a) Aitken mode $(10 \mathrm{~nm} \leq \mathrm{Dp}<100 \mathrm{~nm})$ and (b) accumulation mode $(100 \mathrm{~nm} \leq \mathrm{Dp}<1 \mu \mathrm{m})$ compared to the observations (" $x$ " symbol with error bar representing minimum and maximum observed concentrations) that were compiled and aggregated into $15^{\circ}$ latitude ranges (Heintzenberg et al., 2000). The model is also averaged to the $15^{\circ}$ grid and is shown in red lines for the BASE run, blue lines for the LowNUC run, and green lines for the NoNUC run.

tivation diameter (supersaturation of $0.2 \%$ ) for both largescale clouds and convective clouds in the model. Note that ModelE2-TOMAS cannot capture the observed bimodal distribution when a supersaturation of $1.0 \%$ is assumed for convective clouds, unlike the other TOMAS models (e.g. Pierce et al., 2007; Trivitayanurak et al., 2008): a peak at around
$20-30 \mathrm{~nm}$ appears when the supersaturation of $1.0 \%$ is assumed for convective clouds. This suggests that, compared to GISS GCM II', convective clouds are more frequent in ModelE2. Although the model captures the observations successfully using fixed supersaturation assumptions, future work 
(a) $-75 \mathrm{~S}$ to $-60 \mathrm{~S}$
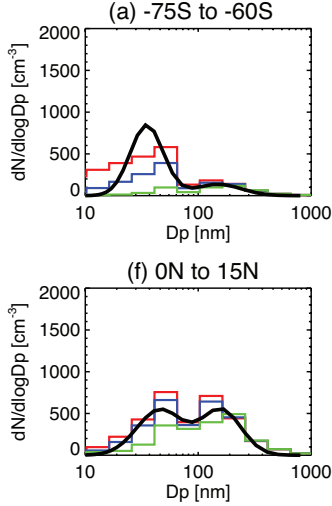

(b) $-60 S$ to $-45 S$

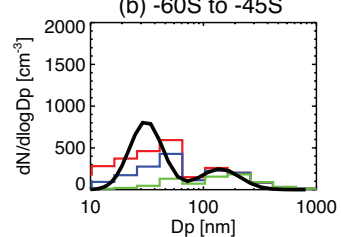

(h) $15 \mathrm{~N}$ to $30 \mathrm{~N}$

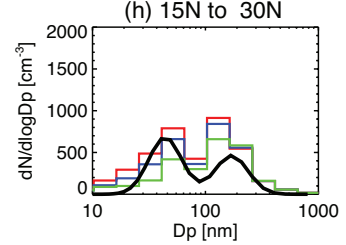

(c) $-45 S$ to $-30 S$

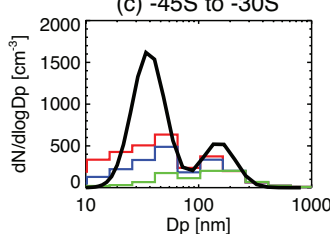

(i) $30 \mathrm{~N}$ to $45 \mathrm{~N}$

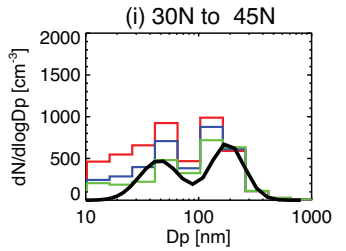

(d) $-30 \mathrm{~S}$ to $-15 \mathrm{~S}$

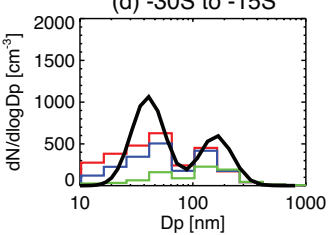

(j) $45 \mathrm{~N}$ to $60 \mathrm{~N}$

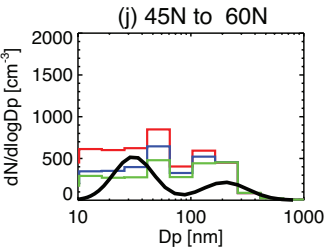

(e) $-15 S$ to $0 S$

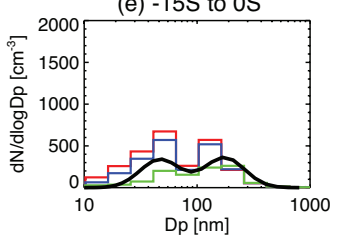

(k) $75 \mathrm{~N}$ to $90 \mathrm{~N}$

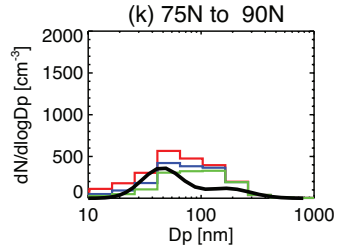

Figure 26. Annually and zonally averaged aerosol size distributions in the marine boundary layer. Observations are from Heintzenberg et al. (2000) and were compiled and aggregated into a $15^{\circ} \times 15^{\circ}$ grid. The model is also averaged to the $15^{\circ}$ grid and is shown as red lines for the BASE run, blue lines for the LowNUC run, and green lines for the NoNUC run.

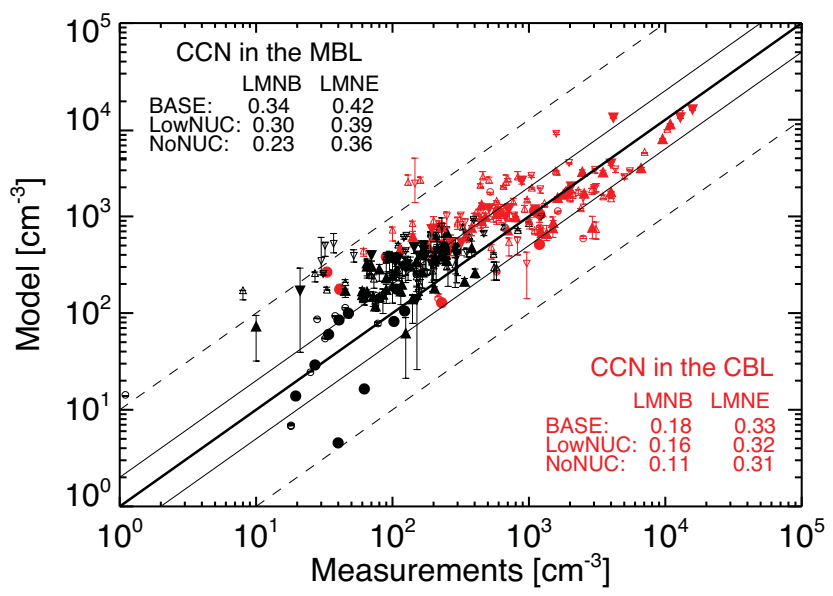

Figure 27. Scatter plot of simulated CCN concentrations in comparison with a data set of CCN measurements compiled by Spracklen et al. (2011). Data are classified into two categories: $\mathrm{CCN}$ in the MBL (in black) and CCN in the CBL (in red). The upper error bar is for the BASE run, the middle symbol for the LowNUC run, and the lower error bar for the NoNUC run. Large and filled symbols are for measurement duration longer than 10 days, and small and open symbols for less than 10 days. Circle symbols are for supersaturations $(s)$ less than $0.2 \%$; upward triangles for $s$ greater than $0.2 \%$ and less than $0.8 \%$; and the downward triangle for $s$ greater than $0.8 \%$.

is needed to link the in-cloud supersaturation to cloud and aerosol properties.

Simulated CCN concentrations are compared against a data set of CCN measurements compiled by Spracklen et al. (2011) in Figs. 27 and 28: see Table 1 in Spracklen et al. (2011) for the details regarding each site. The CCN data set includes a total of 277 measurements at 80 locations using various instruments from 1971 to 2009. Approximately $70 \%$ of the observations were taken after 1990. Most have sampling periods of days to weeks except the observations at Cape Grim and Mace Head. For Cape Grim and Mace Head, an annual cycle is available, so we present them separately in Fig. 28. In Fig. 27, the CCN data are divided into two groups: $\mathrm{CCN}$ in the MBL (marine boundary layer) and $\mathrm{CCN}$ in the CBL (continental boundary layer). Note that all $\mathrm{CCN}$ measurements used here are in the boundary layer. For $\mathrm{CCN}$ in the CBL, the model CCN shows good agreement with the observation in all three simulations $(\mathrm{LMNB}=0.11-$ 0.18 and $\mathrm{LMNE}=0.31-0.33$ ). For $\mathrm{CCN}$ in the MBL, the model predictions are, on average, within a factor of 1.52 of the observations for all three runs but, relative to several measurements of $\mathrm{CCN}$ concentration between $\sim 100$ and $\sim 300 \mathrm{~cm}^{-3}$, are biased high, by roughly a factor of 2 .

For the annual cycle of CCN concentrations at Cape Grim and Mace Head (Fig. 28), the model overpredicts in all months even without nucleation $(\mathrm{NMB}>1.0)$. The $\mathrm{CCN}$ overpredictions at Cape Grim might be influenced by overpredicted $\mathrm{SO}_{2}$ (shown in Fig. 3), which could lead to overpredicted condensational growth of Aitken mode particles. As with the $\mathrm{SO}_{2}$ evaluation in Fig. 3, the $\mathrm{CCN}$ overprediction decreases by sampling adjacent grids toward the ocean (not shown), but the model CCN is still higher than the measurements. Given the fact that most CCN observations have very short duration (days to weeks) in a single year and, according to Spracklen et al. (2011), the relative uncertainties in the measurement data range from about 5 to $40 \%$, mostly in $10-20 \%$ very roughly, the overall model-to-observation agreement is satisfactory.

\section{Conclusions}

We have implemented the TwO-Moment Aerosol Sectional (TOMAS) microphysics model in the new version of the GISS GCM (i.e. ModelE2), called "ModelE2-TOMAS". This paper has compared the global budgets of ModelE2TOMAS to other global aerosol models and evaluates the 


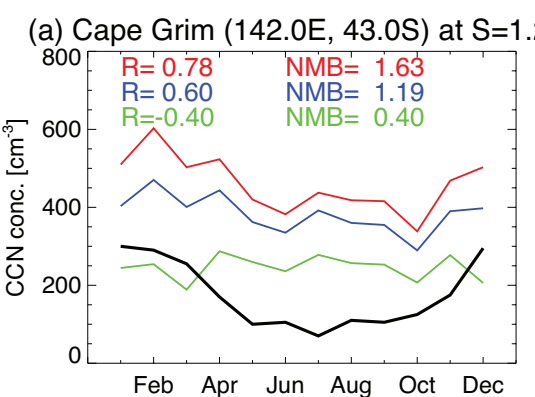

(c) Cape Grim (142.0E, 43.0S) at S=0.23\%

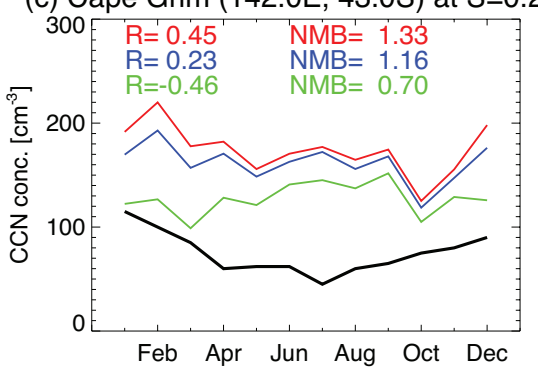

(b) Cape Grim (142.0E, 43.0S) at $\mathrm{S}=0.75 \%$

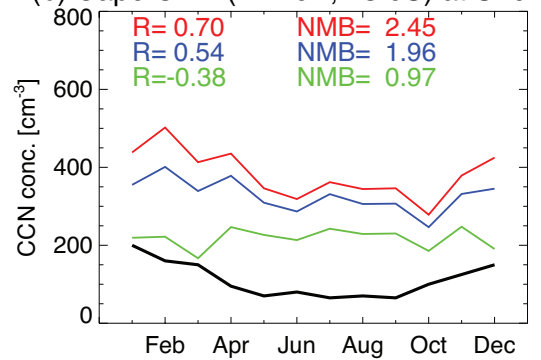

(d) Mace Head ( $10.3 \mathrm{~W}, 53.3 \mathrm{~N})$ at $\mathrm{S}=0.5 \%$

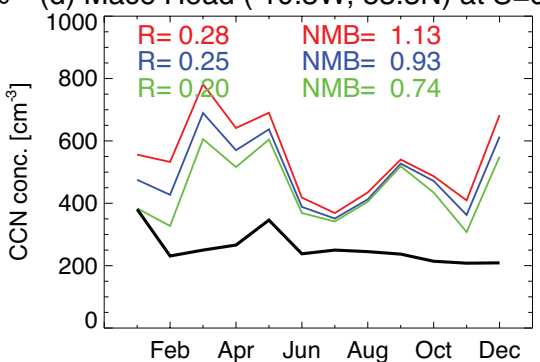

Figure 28. Annual cycle of CCN concentrations at Cape Grim (supersaturations $(s)$ of $1.2 \%$ in a, $0.75 \%$ in $\mathbf{b}$, and $0.23 \%$ in c) and Mace Head ( $s$ of $0.5 \%$ in d). The measured CCN concentrations are shown in black, and the simulated CCN in red for the BASE run, blue for the LowNUC run, and green for the NoNUC run. Correlation $(R)$ and normalized mean bias (NMB) are given.

model with various observations such as aerosol precursor gas concentrations, aerosol mass and number concentrations, and aerosol optical depth.

Global budgets of aerosols and aerosol precursor gases in ModelE2-TOMAS are similar to those in other global aerosol models, and the ModelE2-TOMAS model agrees reasonably (mostly within a factor of 2) with long-term observed aerosol precursor gas and aerosol mass concentrations. The model captures the broad spatial features shown in the MODIS and MISR annual-mean AOD distributions as well as the observed seasonal trends of AOD at several AERONET sites. The model predicts the observed annual-mean CN (the minimum cutoff varying from 3 to $14 \mathrm{~nm}$ ) concentrations very well and the observed vertical profiles of aerosol number over Germany (i.e. the LACE campaign) and in the marine boundary layer. For $\mathrm{CCN}$, the model shows good skill in capturing the observations. We conclude that the model is realistic enough to be useful for many types of scientific study.

However, the evaluation has also highlighted some weaknesses in ModelE2-TOMAS to be revisited in the future. First, ModelE2-TOMAS predicts too much $\mathrm{SO}_{2}$ lifted into the upper/free troposphere over the Pacific Ocean, possibly due to overly strong convective transport. This is also seen in ModelE2-OMA (and in gaseous tracers), suggesting that this might be a host model problem. Second, the the simulated AOD is underpredicted over polluted continents, even though mass concentrations of each aerosol component at the surface are well simulated (or at least not underpredicted) in the model. Missing nitrate in ModelE2-TOMAS may not be the main contributor, as the inclusion of nitrate in ModelE2-OMA decreases its ability to capture the observed seasonality at AERONET polluted continent sites. Third, the model tends to underpredict aerosol loading (and AOD) over biomass burning emission regions. This is a common issue in global aerosol models, and this might be due to underestimation of biomass burning emissions. Fourth, the ModelE2-TOMAS AOD prediction is biased low over the SH high-latitude oceans, which suggests an underpredicted sea-salt burden in this area. Fifth, the simulated CN seasonality is poor at some CBL sites due to overpredicted CN during the wintertime. Similarly, ModelE2-TOMAS predicts the observed number size distributions over European sites during the summer season reasonably, but not for the winter season. The model overpredicts Aitken mode particles during the winter season, which happens even without nucleation, possibly due to a problem in primary emissions representation or a bias in the model scavenging that causes the poor seasonality. Finally, ModelE2-TOMAS seems to predict faster nucleation rates using binary nucleation (Vehkamaki et al., 2002) than other global microphysics models using the same binary nucleation (including GISS-TOMAS). For instance, the observed $\mathrm{CN}$ vertical profiles are captured best when nucleation rates are reduced (our LowNUC run), while Lauer et al. (2005) present significantly underpredicted $\mathrm{CN}$ profiles with the same binary nucleation scheme using ECHAM/MADE. To investigate this issue further, we need to perform a model evaluation against observation-derived nucleation-relevant metrics, which has been done in Wester- 
velt et al. (2013). Because of the fine size assumptions for the primary emissions (see Sect. 4.2 for the details) and/or the fast nucleation rates using binary nucleation in ModelE2TOMAS, we do not include boundary nucleation, as it overpredicted $\mathrm{CN}$ near the surface. We conclude that further work is necessary to improve the realism of some aspects of ModelE2-TOMAS and to better understand the size-resolved physical processes (e.g. microphysics, emissions, and depositions).

Comparing the ModelE2-TOMAS model with the ModelE2-OMA model in ModelE2, some aerosol species burdens and concentrations differ significantly, even with using the same host model and identical anthropogenic emissions, mainly because the deposition parameterizations and some of the emission-related assumptions are different. In the case of sea salt and dust, the size ranges assumed by each model are different, resulting in different emission rates and burdens.

Analysis of multiple aerosol model results help to identify where a model bias might originate from aerosol modelling or the host GCM or elsewhere such as emissions. We found that some of the large differences in aerosol predictions between the two aerosol models are due to aerosol modelling. This is valuable information, as this is not easy to constrain using observations. Having more than one aerosol physics representation in the NASA GISS ModelE2 will serve as a useful tool to study the uncertainty in aerosol modelling and to guide our efforts to improve the models.

\section{Code availability}

Currently, we do not have a publicly available version of either NASA GISS ModelE2-TOMAS or ModelE2 itself. The ModelE2-TOMAS code may be provided upon the request. However, it may be quite challenging to compile and run ModelE2-TOMAS in a new computer environment, as the model has been developed in a NASA NCCS supercomputer (http://www.nccs.nasa.gov/discover_front.html) and a user manual has not been developed.

It is worth noting that the public version of ModelE2 (the TOMAS model is not a part of the standard version of ModelE2) will be available in the next few years, and the NASA GISS ModelE (which has been used for IPCC AR4 simulations) is publicly available: see details in http: //www.giss.nasa.gov/tools/modelE/.

\section{The Supplement related to this article is available online at doi:10.5194/gmd-8-631-2015-supplement.}

Acknowledgements. Funding for this research was supported by the NASA ACMAP and MAP programs. Resources supporting the simulations were provided by the NASA High-End Computing
(HEC) program through the NASA Center for Climate Simulation (NCCS) at Goddard Space Flight Center. We gratefully acknowledge the mission scientists and principal investigators (PIs) who provided the data used in this research effort (EMEP, CASTNET, IMPROVE, and University of Miami networks, AERONET, NASA MODIS and MISR). We also acknowledge the PIs for the CN and CCN surface measurements at the WMO-GAW sites (J. Ogren, Earth System Research Laboratory, NOAA, US; J. Gras, CSIRO Marine and Atmospheric Research, Australia; U. Baltensperger, Paul Scherrer Institute, Switzerland; U. Kaminski, Deutscher Wetterdienst (DWD), Germany; S. G. Jennings, National University of Ireland Galway, Ireland; R. Weller, Alfred Wegener Institute for Polar and Marine Research, Germany; Y. Viisanen, Finnish Meteorological Institute, Finland). We further acknowledge that Cape Grim data are provided by the Australian Bureau of Meteorology (Cape Grim Baseline Air Pollution Station) and CSIRO Ocean and Atmosphere Flagship. We thank Graham Mann (University of Leeds, UK) and Dominick Spracklen (University of Leeds, UK) for providing aerosol number measurement data collection. We also thank Greg Faluvegi (NASA GISS) and Maxwell Kelley (NASA GISS) for providing technical support during the model development. Finally, we thank two anonymous reviewers for constructive comments and suggestions that have improved the paper considerably.

Edited by: F. O'Connor

\section{References}

Abdou, W. A., Diner, D. J., Martonchik, J. V., Bruegge, C. J., Kahn, R. A., Gaitley, B. J., Crean, K. A., Remer, L. A., and Holben, B.: Comparison of coincident Multiangle Imaging Spectroradiometer and Moderate Resolution Imaging Spectroradiometer aerosol optical depths over land and ocean scenes containing Aerosol Robotic Network sites, J. Geophys. Res.-Atmos., 110, D10S07, doi:10.1029/2004jd004693, 2005.

Adams, P. J. and Seinfeld, J. H.: Predicting global aerosol size distributions in general circulation models, J. Geophys. Res.-Atmos. 107, 4370, doi:10.1029/2001JD001010, 2002.

Andres, R. J. and Kasgnoc, A. D.: A time-averaged inventory of subaerial volcanic sulfur emissions, J. Geophys. Res.-Atmospheres, 103, 25251-25261, doi:10.1029/98JD02091, 1998.

Arimoto, R., Ray, B. J., Duce, R. A., Hewitt, A. D., Boldi, R., and Hudson, A.: CONCENTRATIONS, SOURCES, AND FLUXES OF TRACE-ELEMENTS IN THE REMOTE MARINE ATMOSPHERE OF NEW-ZEALAND, J. Geophys. Res.-Atmos., 95, 22389-22405, doi:10.1029/JD095iD13p22389, 1990.

Ayers, G. P., Ivey, J. P., and Gillett, R. W.: COHERENCE BETWEEN SEASONAL CYCLES OF DIMETHYL SULFIDE, METHANESULFONATE AND SULFATE IN MARINE AIR, Nature, 349, 404-406, doi:10.1038/349404a0, 1991.

Ayers, G. P., Bentley, S. T., Ivey, J. P., and Forgan, B. W.: DIMETHYLSULFIDE IN MARINE AIR AT CAPE-GRIM, 41-DEGREES-S, J. Geophys. Res.-Atmos., 100, 21013-21021, doi:10.1029/95jd02144, 1995. 
Baltensperger, U.: Aerosol climatology at the high Alpine site Jungfraujoch, Switzerland, J. Geophys. Res., 102, 19707-19715, 1997.

Bauer, S. E. and Koch, D.: Impact of heterogeneous sulfate formation at mineral dust surfaces on aerosol loads and radiative forcing in the Goddard Institute for Space Studies general circulation model, J. Geophys. Res.-Atmos., 110, D17202, doi:10.1029/2005jd005870, 2005.

Bauer, S. E., Koch, D., Unger, N., Metzger, S. M., Shindell, D. T., and Streets, D. G.: Nitrate aerosols today and in 2030: a global simulation including aerosols and tropospheric ozone, Atmos. Chem. Phys., 7, 5043-5059, doi:10.5194/acp-7-5043-2007, 2007.

Bauer, S. E., Wright, D. L., Koch, D., Lewis, E. R., McGraw, R., Chang, L.-S., Schwartz, S. E., and Ruedy, R.: MATRIX (Multiconfiguration Aerosol TRacker of mIXing state): an aerosol microphysical module for global atmospheric models, Atmos. Chem. Phys., 8, 6003-6035, doi:10.5194/acp-8-60032008, 2008.

Bian, H. S. and Prather, M. J.: Fast-J2: Accurate simulation of stratospheric photolysis in global chemical models, J. Atmos. Chem., 41, 281-296, doi:10.1023/a:1014980619462, 2002.

Boucher, O., Moulin, C., Belviso, S., Aumont, O., Bopp, L., Cosme, E., von Kuhlmann, R., Lawrence, M. G., Pham, M., Reddy, M. S., Sciare, J., and Venkataraman, C.: DMS atmospheric concentrations and sulphate aerosol indirect radiative forcing: a sensitivity study to the DMS source representation and oxidation, Atmos. Chem. Phys., 3, 49-65, doi:10.5194/acp-3-49-2003, 2003.

Boucher, O., Randall, D., Artaxo, P., Bretherton, C., Feingold, G., Forster, P., Kerminen, V.-M., Kondo, Y., Liao, H., Lohmann, U., Rasch, P., Satheesh, S. K., Sherwood, S., Stevens, B., and Zhang, X. Y.: Clouds and Aerosols. In: Climate Change 2013: The Physical Science Basis, contribution of Working Group I to the Fifth Assessment Report of the Intergovernmental Panel on Climate Change, Cambridge University Press, Cambridge, United Kingdom and New York, NY, USA, 571-657, 2013.

Bowman, K. W., Shindell, D. T., Worden, H. M., Lamarque, J. F., Young, P. J., Stevenson, D. S., Qu, Z., de la Torre, M., Bergmann, D., Cameron-Smith, P. J., Collins, W. J., Doherty, R., Dalsøren, S. B., Faluvegi, G., Folberth, G., Horowitz, L. W., Josse, B. M., Lee, Y. H., MacKenzie, I. A., Myhre, G., Nagashima, T., Naik, V., Plummer, D. A., Rumbold, S. T., Skeie, R. B., Strode, S. A., Sudo, K., Szopa, S., Voulgarakis, A., Zeng, G., Kulawik, S. S., Aghedo, A. M., and Worden, J. R.: Evaluation of ACCMIP outgoing longwave radiation from tropospheric ozone using TES satellite observations, Atmos. Chem. Phys., 13, 40574072, doi:10.5194/acp-13-4057-2013, 2013.

Cakmur, R. V., Miller, R. L., Perlwitz, J., Geogdzhayev, I. V., Ginoux, P., Koch, D., Kohfeld, K. E., Tegen, I., and Zender, C. S.: Constraining the magnitude of the global dust cycle by minimizing the difference between a model and observations, J. Geophys. Res.-Atmos., 111, D06207, doi:10.1029/2005jd005791, 2006.

Clarke, A. D. and Kapustin, V. N.: A pacific aerosol survey. Part I: A decade of data on particle production, transport, evolution, and mixing in the troposphere, J. Atmos. Sci., 59, 363-382, doi:10.1175/1520-0469(2002)059<0363:apaspi>2.0.co;2, 2002.

Collaud Coen, M., Weingartner, E., Furger, M., Nyeki, S., Prévôt, A. S. H., Steinbacher, M., and Baltensperger, U.: Aerosol climatology and planetary boundary influence at the Jungfraujoch analyzed by synoptic weather types, Atmos. Chem. Phys., 11, 5931-5944, doi:10.5194/acp-11-5931-2011, 2011.

Debell, L. J., Gebhart, K. A., Malm, W. C., Pitchford, M. L., Schichtel, B. A., and White, W. H.: Spatial and seasonal patterns and temporal variability of haze and its constituents in the United States, Report IV, Cooperative Institute for Research in the Atmosphere, Fort Collins, CO, 2006.

Del Genio, A. D. and Yao, M.-S.: Efficient cumulus parameterization for long-term climate studies: The GISS scheme, The Representation of Cumulus Convection in Numerical Models, Am. Meteorol. Soc., Boston, MA, USA, 181-184 pp., 1993.

Del Genio, A. D., Yao, M. S., Kovari, W., and Lo, K. K. W.: A prognostic cloud water parameterization for global climate models, J. Climate, 9, 270-304, 1996.

Dentener, F., Kinne, S., Bond, T., Boucher, O., Cofala, J., Generoso, S., Ginoux, P., Gong, S., Hoelzemann, J. J., Ito, A., Marelli, L., Penner, J. E., Putaud, J.-P., Textor, C., Schulz, M., van der Werf, G. R., and Wilson, J.: Emissions of primary aerosol and precursor gases in the years 2000 and 1750 prescribed data-sets for AeroCom, Atmos. Chem. Phys., 6, 4321-4344, doi:10.5194/acp-64321-2006, 2006.

Dick, W. D., Saxena, P., and McMurry, P. H.: Estimation of water uptake by organic compounds in submicron aerosols measured during the Southeastern Aerosol and Visibility Study, J. Geophys. Res.-Atmos., 105, 1471-1479, doi:10.1029/1999jd901001, 2000.

Diner, D. J., Beckert, J. C., Reilly, T. H., Bruegge, C. J., Conel, J. E., Kahn, R. A., Martonchik, J. V., Ackerman, T. P., Davies, R., Gerstl, S. A. W., Gordon, H. R., Muller, J. P., Myneni, R. B., Sellers, P. J., Pinty, B., and Verstraete, M. M.: Multi-angle Imaging SpectroRadiometer (MISR) - Instrument description and experiment overview, Ieee Transactions on Geosci. Remote Sens., 36, 1072-1087, doi:10.1109/36.700992, 1998.

Duce, R. A.: Sources, distributions, and fluxes of mineral aerosols and their relationship to climate, Aerosol Forcing of Climate, edited by: Charlson, R. J. and Heintzenberg, J., 43-72 pp., 1995.

Easter, R. C., Ghan, S. J., Zhang, Y., Saylor, R. D., Chapman, E. G., Laulainen, N. S., Abdul-Razzak, H., Leung, L. R., Bian, X. D., and Zaveri, R. A.: MIRAGE: Model description and evaluation of aerosols and trace gases, J. Geophys. Res.-Atmos., 109, D20210, doi:10.1029/2004JD004571, 2004.

Emmons, L. K., Hauglustaine, D. A., Muller, J. F., Carroll, M. A., Brasseur, G. P., Brunner, D., Staehelin, J., Thouret, V., and Marenco, A.: Data composites of airborne observations of tropospheric ozone and its precursors, J. Geophys. Res.-Atmos., 105, 20497-20538, doi:10.1029/2000jd900232, 2000.

Feingold, G., Tzivion, S., and Levin, Z.: EVOLUTION OF RAINDROP SPECTRA .1. SOLUTION TO THE STOCHASTIC COLLECTION BREAKUP EQUATION USING THE METHOD OF MOMENTS, J. Atmos. Sci., 45, 3387-3399, doi:10.1175/1520-0469(1988)045<3387:eorspi>2.0.co;2, 1988.

Forster, P. and Ramaswamy, V.: Changes in Atmospheric Constituents and in Radiative Forcing, Climate Change 2007: The Physical Science Basis, edited by: Solomon, S., Qin, D., Manning, M., Marquis, M., Averyt, K., Tignor, M. M. B., Miller, H. L., and Chen, Z. L., 129-234 pp., 2007.

Ginoux, P., Chin, M., Tegen, I., Prospero, J. M., Holben, B., Dubovik, O., and Lin, S. J.: Sources and distributions of dust 
aerosols simulated with the GOCART model, J. Geophys. Res.Atmos., 106, 20255-20273, 2001.

Gong, S. L.: A parameterization of sea-salt aerosol source function for sub- and super-micron particles, Global Biogeochem. Cycles, 17, 1097, doi:10.1029/2003gb002079, 2003.

Hand, J. L., Copeland, S. A., Day, D. E., Dillner, A. M., Indresand, H., Malm, W. C., McDade, C. E., Moore, C. T., Pitchford, M. L., Schichtel, B. A., and Watson, J. G.: Spatial and Seasonal Patterns and Temporal Variability of Haze and its Constituents in the United States: Report V, Colo. State Univ., Fort Collins, 2011.

Hansen, J., Russell, G., Rind, D., Stone, P., Lacis, A., Lebedeff, S., Ruedy, R., and Travis, L.: Efficient 3-Dimensional GlobalModels for Climate Studies - Model-I and Model-Ii, Mon. Weather Rev., 111, 609-662, 1983.

Harrington, D. Y. and Kreidenweis, S. M.: Simulations of sulfate aerosol dynamics - Part II. Model intercomparison, Atmos. Environ., 32, 1701-1709, doi:10.1016/S1352-2310(97)00453-6, 1998.

Heintzenberg, J., Covert, D. C., and Van Dingenen, R.: Size distribution and chemical composition of marine aerosols: a compilation and review, Tellus Series B-Chemical and Physical Meteorology, 52, 1104-1122, doi:10.1034/j.1600-0889.2000.00136.x, 2000.

Hoell, J. M., Davis, D. D., Jacob, D. J., Rodgers, M. O., Newell, R. E., Fuelberg, H. E., McNeal, R. J., Raper, J. L., and Bendura, R. J.: Pacific Exploratory Mission in the tropical Pacific: PEMTropics A, August-September 1996, J. Geophys. Res.-Atmos., 104, 5567-5583, doi:10.1029/1998jd100074, 1999.

Holben, B. N., Eck, T. F., Slutsker, I., Tanre, D., Buis, J. P., Setzer, A., Vermote, E., Reagan, J. A., Kaufman, Y. J., Nakajima, T., Lavenu, F., Jankowiak, I., and Smirnov, A.: AERONET - A federated instrument network and data archive for aerosol characterization, Rem. Sens. Environ., 66, 1-16, doi:10.1016/s00344257(98)00031-5, 1998.

Holben, B. N., Tanre, D., Smirnov, A., Eck, T. F., Slutsker, I., Abuhassan, N., Newcomb, W. W., Schafer, J. S., Chatenet, B., Lavenu, F., Kaufman, Y. J., Castle, J. V., Setzer, A., Markham, B., Clark, D., Frouin, R., Halthore, R., Karneli, A., O'Neill, N. T., Pietras, C., Pinker, R. T., Voss, K., and Zibordi, G.: An emerging ground-based aerosol climatology: Aerosol optical depth from AERONET, J. Geophys. Res.-Atmos., 106, 12067-12097, doi:10.1029/2001jd900014, 2001.

Hsu, N. C., Tsay, S. C., King, M. D., and Herman, J. R.: Deep blue retrievals of Asian aerosol properties during ACE-Asia, Ieee T. Geosci. Rem. Sens., 44, 3180-3195, doi:10.1109/tgrs.2006.879540, 2006.

Jourdain, B. and Legrand, M.: Seasonal variations of atmospheric dimethylsulfide, dimethylsulfoxide, sulfur dioxide, methanesulfonate, and non-sea-salt sulfate aerosols at Dumont d'Urville (coastal Antarctica) (December 1998 to July 1999), J. Geophys. Res.-Atmos., 106, 14391-14408, doi:10.1029/2000jd900841, 2001.

Jung, J. G., Adams, P. J., and Pandis, S. N.: Simulating the size distribution and chemical composition of ultrafine particles during nucleation events, Atmos. Environ., 40, 2248-2259, 2006.

Jung, J. G., Fountoukis, C., Adams, P. J., and Pandis, S. N.: Simulation of in situ ultrafine particle formation in the eastern United States using PMCAMx-UF, J. Geophys. Res.-Atmos., 115, D03203, doi:10.1029/2009jd012313, 2010.
Kahn, R. A., Gaitley, B. J., Martonchik, J. V., Diner, D. J., Crean, K. A., and Holben, B.: Multiangle Imaging Spectroradiometer (MISR) global aerosol optical depth validation based on 2 years of coincident Aerosol Robotic Network (AERONET) observations, J. Geophys. Res.-Atmos., 110, D10s04, doi:10.1029/2004jd004706, 2005.

Kettle, A. J. and Andreae, M. O.: Flux of dimethylsulfide from the oceans: A comparison of updated data sets and flux models, J. Geophys. Res.-Atmos., 105, 26793-26808, doi:10.1029/2000JD900252, 2000.

Kettle, A. J., Andreae, M. O., Amouroux, D., Andreae, T. W., Bates, T. S., Berresheim, H., Bingemer, H., Boniforti, R., Curran, M. A. J., DiTullio, G. R., Helas, G., Jones, G. B., Keller, M. D., Kiene, R. P., Leck, C., Levasseur, M., Malin, G., Maspero, M., Matrai, P., McTaggart, A. R., Mihalopoulos, N., Nguyen, B. C., Novo, A., Putaud, J. P., Rapsomanikis, S., Roberts, G., Schebeske, G., Sharma, S., Simo, R., Staubes, R., Turner, S., and Uher, G.: A global database of sea surface dimethylsulfide (DMS) measurements and a procedure to predict sea surface DMS as a function of latitude, longitude, and month, Global Biogeochem. Cycles, 13, 399-444, doi:10.1029/1999gb900004, 1999.

Koch, D., Jacob, D., Tegen, I., Rind, D., and Chin, M.: Tropospheric sulfur simulation and sulfate direct radiative forcing in the Goddard Institute for Space Studies general circulation model, J. Geophys. Res.-Atmos., 104, 23799-23822, doi:10.1029/1999jd900248, 1999.

Koch, D., Schmidt, G. A., and Field, C. V.: Sulfur, sea salt, and radionuclide aerosols in GISS ModelE, J. Geophys. Res.-Atmos., 111, D06206, doi:10.1029/2004jd005550, 2006.

Koch, D., Bond, T. C., Streets, D., Unger, N., and van der Werf, G. R.: Global impacts of aerosols from particular source regions and sectors, J. Geophys. Res.-Atmos., 112, D02205, doi:10.1029/2005jd007024, 2007.

Koch, D., Bauer, S. E., Del Genio, A., Faluvegi, G., McConnell, J. R., Menon, S., Miller, R. L., Rind, D., Ruedy, R., Schmidt, G. A., and Shindell, D.: Coupled Aerosol-Chemistry-Climate Twentieth-Century Transient Model Investigation: Trends in Short-Lived Species and Climate Responses, J. Climate, 24, 2693-2714, doi:10.1175/2011jcli3582.1, 2011.

Korhonen, H., Carslaw, K. S., Spracklen, D. V., Mann, G. W., and Woodhouse, M. T.: Influence of oceanic dimethyl sulfide emissions on cloud condensation nuclei concentrations and seasonality over the remote Southern Hemisphere oceans: A global model study, J. Geophys. Res.-Atmos., 113, D15204, doi:10.1029/2007jd009718, 2008.

Lamarque, J.-F., Dentener, F., McConnell, J., Ro, C.-U., Shaw, M., Vet, R., Bergmann, D., Cameron-Smith, P., Dalsoren, S., Doherty, R., Faluvegi, G., Ghan, S. J., Josse, B., Lee, Y. H., MacKenzie, I. A., Plummer, D., Shindell, D. T., Skeie, R. B., Stevenson, D. S., Strode, S., Zeng, G., Curran, M., Dahl-Jensen, D., Das, S., Fritzsche, D., and Nolan, M.: Multi-model mean nitrogen and sulfur deposition from the Atmospheric Chemistry and Climate Model Intercomparison Project (ACCMIP): evaluation of historical and projected future changes, Atmos. Chem. Phys., 13, 7997-8018, doi:10.5194/acp-13-7997-2013, $2013 a$.

Lamarque, J.-F., Shindell, D. T., Josse, B., Young, P. J., Cionni, I., Eyring, V., Bergmann, D., Cameron-Smith, P., Collins, W. J., Doherty, R., Dalsoren, S., Faluvegi, G., Folberth, G., Ghan, S. J., Horowitz, L. W., Lee, Y. H., MacKenzie, I. A., Nagashima, T., 
Naik, V., Plummer, D., Righi, M., Rumbold, S. T., Schulz, M., Skeie, R. B., Stevenson, D. S., Strode, S., Sudo, K., Szopa, S., Voulgarakis, A., and Zeng, G.: The Atmospheric Chemistry and Climate Model Intercomparison Project (ACCMIP): overview and description of models, simulations and climate diagnostics, Geosci. Model Dev., 6, 179-206, doi:10.5194/gmd-6-179-2013, $2013 b$.

Lauer, A., Hendricks, J., Ackermann, I., Schell, B., Hass, H., and Metzger, S.: Simulating aerosol microphysics with the ECHAM/MADE GCM - Part I: Model description and comparison with observations, Atmos. Chem. Phys., 5, 3251-3276, doi:10.5194/acp-5-3251-2005, 2005.

Lee, Y. H. and Adams, P. J.: Evaluation of aerosol distributions in the GISS-TOMAS global aerosol microphysics model with remote sensing observations, Atmos. Chem. Phys., 10, 2129-2144, doi:10.5194/acp-10-2129-2010, 2010.

Lee, Y. H. and Adams, P. J.: A Fast and Efficient Version of the TwO-Moment Aerosol Sectional (TOMAS) Global Aerosol Microphysics Model, Aerosol Sci. Technol., 46, 678-689, doi:10.1080/02786826.2011.643259, 2012.

Lee, Y. H., Chen, K., and Adams, P. J.: Development of a global model of mineral dust aerosol microphysics, Atmos. Chem. Phys., 9, 2441-2458, doi:10.5194/acp-9-2441-2009, 2009.

Lee, Y. H., Lamarque, J.-F., Flanner, M. G., Jiao, C., Shindell, D. T., Berntsen, T., Bisiaux, M. M., Cao, J., Collins, W. J., Curran, M., Edwards, R., Faluvegi, G., Ghan, S., Horowitz, L. W., McConnell, J. R., Ming, J., Myhre, G., Nagashima, T., Naik, V., Rumbold, S. T., Skeie, R. B., Sudo, K., Takemura, T., Thevenon, F., Xu, B., and Yoon, J.-H.: Evaluation of preindustrial to presentday black carbon and its albedo forcing from Atmospheric Chemistry and Climate Model Intercomparison Project (ACCMIP), Atmos. Chem. Phys., 13, 2607-2634, doi:10.5194/acp13-2607-2013, 2013a.

Lee, Y. H., Pierce, J. R., and Adams, P. J.: Representation of nucleation mode microphysics in a global aerosol model with sectional microphysics, Geosci. Model Dev., 6, 1221-1232, doi:10.5194/gmd-6-1221-2013, 2013 b.

Liss, P. S. and Merlivat, L.: Air-sea gas exchange rates: Introduction and synthesis, The Role of Air-Sea Exchange in Geochemical Cycling, Springer, New York, 1986.

Liu, X. H., Penner, J. E., and Herzog, M.: Global modeling of aerosol dynamics: Model description, evaluation, and interactions between sulfate and nonsulfate aerosols, J. Geophys. Res.Atmos., 110, D18206, doi:10.1029/2004jd005674, 2005.

Lohmann, U. and Feichter, J.: Global indirect aerosol effects: a review, Atmos. Chem. Phys., 5, 715-737, doi:10.5194/acp-5-7152005, 2005.

Lovblad, G., Tarrason, L., and Torseth, K.: EMEP Assessment, Part 1: European Perspective, edited by: Norwegian Meteorol. Inst., Oslo, 15-46, 2004, Norwegian Meteorological Institute, Oslo, 2004.

Mahowald, N. M., Engelstaedter, S., Luo, C., Sealy, A., Artaxo, P., Benitez-Nelson, C., Bonnet, S., Chen, Y., Chuang, P. Y., Cohen, D. D., Dulac, F., Herut, B., Johansen, A. M., Kubilay, N., Losno, R., Maenhaut, W., Paytan, A., Prospero, J. A., Shank, L. M., and Siefert, R. L.: Atmospheric Iron Deposition: Global Distribution, Variability, and Human Perturbations, Annu. Rev. Mar. Sci., 1, 245-278, doi:10.1146/annurev.marine.010908.163727, 2009.
Malm, W. C., Schichtel, B. A., Ames, R. B., and Gebhart, K. A.: A 10-year spatial and temporal trend of sulfate across the United States, J. Geophys. Res.-Atmos., 107, 4627, doi:10.1029/2002jd002107, 2002.

Mann, G. W., Carslaw, K. S., Spracklen, D. V., Ridley, D. A., Manktelow, P. T., Chipperfield, M. P., Pickering, S. J., and Johnson, C. E.: Description and evaluation of GLOMAP-mode: a modal global aerosol microphysics model for the UKCA composition-climate model, Geosci. Model Dev., 3, 519-551, doi:10.5194/gmd-3-519-2010, 2010.

Menon, S., Del Genio, A. D., Koch, D., and Tselioudis, G.: GCM Simulations of the aerosol indirect effect: Sensitivity to cloud parameterization and aerosol burden, J. Atmos. Sci., 59, 692-713, doi:10.1175/1520-0469(2002)059<0692:gsotai>2.0.co;2, 2002.

Menon, S., Del Genio, A. D., Kaufman, Y., Bennartz, R., Koch, D., Loeb, N., and Orlikowski, D.: Analyzing signatures of aerosolcloud interactions from satellite retrievals and the GISS GCM to constrain the aerosol indirect effect, J. Geophys. Res.-Atmos., 113, D14s22, doi:10.1029/2007jd009442, 2008.

Merikanto, J., Spracklen, D. V., Mann, G. W., Pickering, S. J., and Carslaw, K. S.: Impact of nucleation on global CCN, Atmos. Chem. Phys., 9, 8601-8616, doi:10.5194/acp-9-8601-2009, 2009.

Miller, R. L., Cakmur, R. V., Perlwitz, J., Geogdzhayev, I. V., Ginoux, P., Koch, D., Kohfeld, K. E., Prigent, C., Ruedy, R., Schmidt, G. A., and Tegen, I.: Mineral dust aerosols in the NASA goddard institute for Space Sciences ModelE atmospheric general circulation model, J. Geophys. Res.-Atmos., 111, D06208, doi:10.1029/2005jd005796, 2006.

Mishchenko, M. I., Travis, L. D., and Mackowski, D. W.: Tmatrix computations of light scattering by nonspherical particles: A review, J. Quant. Spectr. Radiat. T., 55, 535-575, doi:10.1016/0022-4073(96)00002-7, 1996.

Modgil, M. S., Kumar, S., Tripathi, S. N., and Lovejoy, E. R.: A parameterization of ion-induced nucleation of sulphuric acid and water for atmospheric conditions, J. Geophys. Res.-Atmos., 110, D19205, doi:10.1029/2004jd005475, 2005.

Monahan, E. C., Spiel, D. E., and David, K. L.: A model of marine aerosol generation via whitecaps and wave disruption, in Oceanic Whitecaps, Oceanographic Sciences Library, edited by: Monahan, E. C. and Mac Niocaill, G., D. Reidel Publishing, Dordrecht, 167-174 pp., 1986.

Myhre, G., Samset, B. H., Schulz, M., Balkanski, Y., Bauer, S., Berntsen, T. K., Bian, H., Bellouin, N., Chin, M., Diehl, T., Easter, R. C., Feichter, J., Ghan, S. J., Hauglustaine, D., Iversen, T., Kinne, S., Kirkevåg, A., Lamarque, J.-F., Lin, G., Liu, X., Lund, M. T., Luo, G., Ma, X., van Noije, T., Penner, J. E., Rasch, P. J., Ruiz, A., Seland, Ø., Skeie, R. B., Stier, P., Takemura, T., Tsigaridis, K., Wang, P., Wang, Z., Xu, L., Yu, H., Yu, F., Yoon, J.-H., Zhang, K., Zhang, H., and Zhou, C.: Radiative forcing of the direct aerosol effect from AeroCom Phase II simulations, Atmos. Chem. Phys., 13, 1853-1877, doi:10.5194/acp-13-18532013, 2013a.

Myhre, G., Shindell, D., Brèon, F.-M., Collins, W., Fuglestvedt, J., Huang, J., Koch, D., Lamarque, J. F., Lee, D., Mendoza, B., Nakajima, T., Robock, A., Stephens, G., Takemura, T., and Zhang, H.: Anthropogenic and Natural Radiative Forcing, in: Climate Change 2013: The Physical Science Basis., Contribution of Working Group I to the Fifth Assessment Report of the Inter- 
governmental Panel on Climate Change, Cambridge University Press, Cambridge, United Kingdom and New York, NY, USA, 2013b.

Nabat, P., Somot, S., Mallet, M., Chiapello, I., Morcrette, J. J., Solmon, F., Szopa, S., Dulac, F., Collins, W., Ghan, S., Horowitz, L. W., Lamarque, J. F., Lee, Y. H., Naik, V., Nagashima, T., Shindell, D., and Skeie, R.: A 4-D climatology (1979-2009) of the monthly tropospheric aerosol optical depth distribution over the Mediterranean region from a comparative evaluation and blending of remote sensing and model products, Atmos. Meas. Tech., 6, 1287-1314, doi:10.5194/amt-6-1287-2013, 2013.

Naik, V., Voulgarakis, A., Fiore, A. M., Horowitz, L. W., Lamarque, J.-F., Lin, M., Prather, M. J., Young, P. J., Bergmann, D., Cameron-Smith, P. J., Cionni, I., Collins, W. J., Dalsøren, S. B., Doherty, R., Eyring, V., Faluvegi, G., Folberth, G. A., Josse, B., Lee, Y. H., MacKenzie, I. A., Nagashima, T., van Noije, T. P. C., Plummer, D. A., Righi, M., Rumbold, S. T., Skeie, R., Shindell, D. T., Stevenson, D. S., Strode, S., Sudo, K., Szopa, S., and Zeng, G.: Preindustrial to present-day changes in tropospheric hydroxyl radical and methane lifetime from the Atmospheric Chemistry and Climate Model Intercomparison Project (ACCMIP), Atmos. Chem. Phys., 13, 5277-5298, doi:10.5194/acp-13-5277-2013, 2013.

Napari, I., Noppel, M., Vehkamaki, H., and Kulmala, M.: Parametrization of ternary nucleation rates for H2SO4NH3-H2O vapors, J. Geophys. Res.-Atmos., 107, 4381, doi:10.1029/2002JD002132, 2002.

Nenes, A. and Seinfeld, J. H.: Parameterization of cloud droplet formation in global climate models, J. Geophys. Res.-Atmos., 108, published online, 2003.

Nenes, A., Pandis, S. N., and Pilinis, C.: ISORROPIA: A New Thermodynamic Equilibrium Model for Multiphase Multicomponent Inorganic Aerosols, Aquatic Geochemistry, 4, 123-152, doi:10.1023/A:1009604003981, 1998.

Nguyen, B. C., Mihalopoulos, N., Putaud, J. P., Gaudry, A., Gallet, L., Keene, W. C., and Galloway, J. N.: COVARIATIONS IN OCEANIC DIMETHYL SULFIDE, ITS OXIDATIONPRODUCTS AND RAIN ACIDITY AT AMSTERDAM ISLAND IN THE SOUTHERN INDIAN-OCEAN, J. Atmos. Chem., 15, 39-53, doi:10.1007/bf00053608, 1992.

Nightingale, P. D., Malin, G., Law, C. S., Watson, A. J., Liss, P. S., Liddicoat, M. I., Boutin, J., and Upstill-Goddard, R. C.: In situ evaluation of air-sea gas exchange parameterizations using novel conservative and volatile tracers, Global Biogeochem. Cycles, 14, 373-387, doi:10.1029/1999gb900091, 2000.

Petzold, A., Fiebig, M., Flentje, H., Keil, A., Leiterer, U., Schroder, F., Stifter, A., Wendisch, M., and Wendling, P.: Vertical variability of aerosol properties observed at a continental site during the Lindenberg Aerosol Characterization Experiment (LACE 98), J. Geophys. Res.-Atmos., 107, 8128, 8128, doi:10.1029/2001jd001043, 2002.

Pierce, J. R. and Adams, P. J.: Global evaluation of CCN formation by direct emission of sea salt and growth of ultrafine sea salt, J. Geophys. Res.-Atmos., 111, D06203, doi:10.1029/2005JD006186, 2006.

Pierce, J. R. and Adams, P. J.: A Computationally Efficient Aerosol Nucleation/Condensation Method: Pseudo-Steady-State Sulfuric Acid, Aerosol Sci. Technol., 43, 216-226, 2009a.
Pierce, J. R. and Adams, P. J.: Uncertainty in global CCN concentrations from uncertain aerosol nucleation and primary emission rates, Atmos. Chem. Phys., 9, 1339-1356, doi:10.5194/acp-91339-2009, 2009b.

Pierce, J. R., Chen, K., and Adams, P. J.: Contribution of primary carbonaceous aerosol to cloud condensation nuclei: processes and uncertainties evaluated with a global aerosol microphysics model, Atmos. Chem. Phys., 7, 5447-5466, doi:10.5194/acp-75447-2007, 2007.

Prather, M. J.: Numerical Advection by Conservation of 2nd-Order Moments, J. Geophys. Res.-Atmos., 91, 6671-6681, 1986.

Prospero, J. M. and Bonatti, E.: CONTINENTAL DUST IN ATMOSPHERE OF EASTERN EQUATORIAL PACIFIC, J. Geophys. Res., 74, 3362-3371, doi:10.1029/JC074i013p03362, 1969.

Prospero, J. M., Bullard, J. E., and Hodgkins, R.: HighLatitude Dust Over the North Atlantic: Inputs from Icelandic Proglacial Dust Storms, Science, 335, 1078-1082, doi:10.1126/science.1217447, 2012.

Putaud, J. P.: A European aerosol phenomenology; physical and chemical characteristics of particulate matter at kerbside, urban, rural and background sites in Europe, European Commission, EUR 20411 EN, 2003.

Putaud, J. P., Van Dingenen, R., Alastuey, A., Bauer, H., Birmili, W., Cyrys, J., Flentje, H., Fuzzi, S., Gehrig, R., Hansson, H. C., Harrison, R. M., Herrmann, H., Hitzenberger, R., Hueglin, C., Jones, A. M., Kasper-Giebl, A., Kiss, G., Kousa, A., Kuhlbusch, T. A. J., Loeschau, G., Maenhaut, W., Molnar, A., Moreno, T., Pekkanen, J., Perrino, C., Pitz, M., Puxbaum, H., Querol, X., Rodriguez, S., Salma, I., Schwarz, J., Smolik, J., Schneider, J., Spindler, G., ten Brink, H., Tursic, J., Viana, M., Wiedensohler, A., and Raes, F.: A European aerosol phenomenology-3: Physical and chemical characteristics of particulate matter from 60 rural, urban, and kerbside sites across Europe, Atmos. Environ., 44, 1308-1320, doi:10.1016/j.atmosenv.2009.12.011, 2010.

Raper, J. L., Kleb, M. M., Jacob, D. J., Davis, D. D., Newell, R. E., Fuelberg, H. E., Bendura, R. J., Hoell, J. M., and McNeal, R. J.: Pacific Exploratory Mission in the tropical Pacific: PEMTropics B, March-April 1999, J. Geophys. Res.-Atmos., 106, 32401-32425, doi:10.1029/2000jd900833, 2001.

Remer, L. A., Kleidman, R. G., Levy, R. C., Kaufman, Y. J., Tanre, D., Mattoo, S., Martins, J. V., Ichoku, C., Koren, I., Yu, H., and Holben, B. N.: Global aerosol climatology from the MODIS satellite sensors, J. Geophys. Res.-Atmos., 113, D14s07, doi:10.1029/2007jd009661, 2008.

Rienecker, M. M., Suarez, M. J., Gelaro, R., Todling, R., Bacmeister, J., Liu, E., Bosilovich, M. G., Schubert, S. D., Takacs, L., Kim, G.-K., Bloom, S., Chen, J., Collins, D., Conaty, A., da Silva, A., Gu, W., Joiner, J., Koster, R. D., Lucchesi, R., Molod, A., Owens, T., Pawson, S., Pegion, P., Redder, C. R., Reichle, R., Robertson, F. R., Ruddick, A. G., Sienkiewicz, M., and Woollen, J.: MERRA: NASA's Modern-Era Retrospective Analysis for Research and Applications, J Climate, 24, 3624-3648, doi:10.1175/JCLI-D-11-00015.1, 2011.

Savoie, D. L. and Prospero, J. M.: COMPARISON OF OCEANIC AND CONTINENTAL SOURCES OF NON-SEA-SALT SULFATE OVER THE PACIFIC-OCEAN, Nature, 339, 685-687, doi:10.1038/339685a0, 1989.

Schmidt, G. A., Ruedy, R., Hansen, J. E., Aleinov, I., Bell, N., Bauer, M., Bauer, S., Cairns, B., Canuto, V., Cheng, Y., Del Ge- 
nio, A., Faluvegi, G., Friend, A. D., Hall, T. M., Hu, Y. Y., Kelley, M., Kiang, N. Y., Koch, D., Lacis, A. A., Lerner, J., Lo, K. K., Miller, R. L., Nazarenko, L., Oinas, V., Perlwitz, J., Perlwitz, J., Rind, D., Romanou, A., Russell, G. L., Sato, M., Shindell, D. T., Stone, P. H., Sun, S., Tausnev, N., Thresher, D., and Yao, M. S.: Present-day atmospheric simulations using GISS ModelE: Comparison to in situ, satellite, and reanalysis data, J. Climate, 19, 153-192, doi:10.1175/jcli3612.1, 2006.

Schmidt, G. A., Kelley, M., Nazarenko, L., Ruedy, R., Russell, G. L., Aleinov, I., Bauer, M., Bauer, S. E., Bhat, M. K., Bleck, R., Canuto, V., Chen, Y.-H., Cheng, Y., Clune, T. L., Del Genio, A., de Fainchtein, R., Faluvegi, G., Hansen, J. E., Healy, R. J., Kiang, N. Y., Koch, D., Lacis, A. A., LeGrande, A. N., Lerner, J., Lo, K. K., Matthews, E. E., Menon, S., Miller, R. L., Oinas, V., Oloso, A. O., Perlwitz, J. P., Puma, M. J., Putman, W. M., Rind, D., Romanou, A., Sato, M., Shindell, D. T., Sun, S., Syed, R. A., Tausnev, N., Tsigaridis, K., Unger, N., Voulgarakis, A., Yao, M.-S., and Zhang, J.: Configuration and assessment of the GISS ModelE2 contributions to the CMIP5 archive, J. Adv. Model. Earth Syst., 6, 141-184, doi:10.1002/2013ms000265, 2014.

Sciare, J., Baboukas, E., and Mihalopoulos, N.: Short-term variability of atmospheric DMS and its oxidation products at Amsterdam Island during summer time, J. Atmos. Chem., 39, 281-302, doi:10.1023/a:1010631305307, 2001.

Seinfeld, J. H. and Pandis, S. N.: Atmospheric Chemistry and Physics, John Wiley and Sons, New York, 1998.

Shindell, D. T., Faluvegi, G., Unger, N., Aguilar, E., Schmidt, G. A., Koch, D. M., Bauer, S. E., and Miller, R. L.: Simulations of preindustrial, present-day, and 2100 conditions in the NASA GISS composition and climate model G-PUCCINI, Atmos. Chem. Phys., 6, 4427-4459, doi:10.5194/acp-6-4427-2006, 2006.

Shindell, D., Faluvegi, G., Walsh, M., Anenberg, S. C., Van Dingenen, R., Muller, N. Z., Austin, J., Koch, D., and Milly, G.: Climate, health, agricultural and economic impacts of tighter vehicle-emission standards, Nature Climate Change, 1, 59-66, doi:10.1038/nclimate1066, 2011.

Shindell, D. T., Lamarque, J.-F., Schulz, M., Flanner, M., Jiao, C., Chin, M., Young, P. J., Lee, Y. H., Rotstayn, L., Mahowald, N., Milly, G., Faluvegi, G., Balkanski, Y., Collins, W. J., Conley, A. J., Dalsoren, S., Easter, R., Ghan, S., Horowitz, L., Liu, X., Myhre, G., Nagashima, T., Naik, V., Rumbold, S. T., Skeie, R., Sudo, K., Szopa, S., Takemura, T., Voulgarakis, A., Yoon, J.-H., and Lo, F.: Radiative forcing in the ACCMIP historical and future climate simulations, Atmos. Chem. Phys., 13, 2939-2974, doi:10.5194/acp-13-2939-2013, 2013.

Sihto, S.-L., Kulmala, M., Kerminen, V.-M., Dal Maso, M., Petäjä, T., Riipinen, I., Korhonen, H., Arnold, F., Janson, R., Boy, M., Laaksonen, A., and Lehtinen, K. E. J.: Atmospheric sulphuric acid and aerosol formation: implications from atmospheric measurements for nucleation and early growth mechanisms, Atmos. Chem. Phys., 6, 4079-4091, doi:10.5194/acp-6-4079-2006, 2006.

Singh, S., Adams, P. J., Misquitta, A., Lee, K. J., Lipsky, E. M., and Robinson, A. L.: Computational Analysis of Particle Nucleation in Dilution Tunnels: Effects of Flow Configuration and Tunnel Geometry, Aerosol Sci. Technol., 48, 638-648, doi:10.1080/02786826.2014.910291, 2014.
Spracklen, D. V., Pringle, K. J., Carslaw, K. S., Chipperfield, M. P., and Mann, G. W.: A global off-line model of sizeresolved aerosol microphysics: I. Model development and prediction of aerosol properties, Atmos. Chem. Phys., 5, 2227 2252, doi:10.5194/acp-5-2227-2005, 2005.

Spracklen, D. V., Carslaw, K. S., Merikanto, J., Mann, G. W., Reddington, C. L., Pickering, S., Ogren, J. A., Andrews, E., Baltensperger, U., Weingartner, E., Boy, M., Kulmala, M., Laakso, L., Lihavainen, H., Kivekäs, N., Komppula, M., Mihalopoulos, N., Kouvarakis, G., Jennings, S. G., O’Dowd, C., Birmili, W., Wiedensohler, A., Weller, R., Gras, J., Laj, P., Sellegri, K., Bonn, B., Krejci, R., Laaksonen, A., Hamed, A., Minikin, A., Harrison, R. M., Talbot, R., and Sun, J.: Explaining global surface aerosol number concentrations in terms of primary emissions and particle formation, Atmos. Chem. Phys., 10, 4775-4793, doi:10.5194/acp-10-4775-2010, 2010.

Spracklen, D. V., Carslaw, K. S., Pöschl, U., Rap, A., and Forster, P. M.: Global cloud condensation nuclei influenced by carbonaceous combustion aerosol, Atmos. Chem. Phys., 11, 9067-9087, doi:10.5194/acp-11-9067-2011, 2011.

Stevens, R. G., Pierce, J. R., Brock, C. A., Reed, M. K., Crawford, J. H., Holloway, J. S., Ryerson, T. B., Huey, L. G., and Nowak, J. B.: Nucleation and growth of sulfate aerosol in coal-fired power plant plumes: sensitivity to background aerosol and meteorology, Atmos. Chem. Phys., 12, 189-206, doi:10.5194/acp12-189-2012, 2012.

Stevenson, D. S., Young, P. J., Naik, V., Lamarque, J.-F., Shindell, D. T., Voulgarakis, A., Skeie, R. B., Dalsoren, S. B., Myhre, G., Berntsen, T. K., Folberth, G. A., Rumbold, S. T., Collins, W. J., MacKenzie, I. A., Doherty, R. M., Zeng, G., van Noije, T. P. C., Strunk, A., Bergmann, D., Cameron-Smith, P., Plummer, D. A., Strode, S. A., Horowitz, L., Lee, Y. H., Szopa, S., Sudo, K., Nagashima, T., Josse, B., Cionni, I., Righi, M., Eyring, V., Conley, A., Bowman, K. W., Wild, O., and Archibald, A.: Tropospheric ozone changes, radiative forcing and attribution to emissions in the Atmospheric Chemistry and Climate Model Intercomparison Project (ACCMIP), Atmos. Chem. Phys., 13, 3063-3085, doi:10.5194/acp-13-3063-2013, 2013.

Stier, P., Feichter, J., Kinne, S., Kloster, S., Vignati, E., Wilson, J., Ganzeveld, L., Tegen, I., Werner, M., Balkanski, Y., Schulz, M., Boucher, O., Minikin, A., and Petzold, A.: The aerosol-climate model ECHAM5-HAM, Atmos. Chem. Phys., 5, 1125-1156, doi:10.5194/acp-5-1125-2005, 2005.

Taylor, K. E., Stouffer, R. J., and Meehl, G. A.: AN OVERVIEW OF CMIP5 AND THE EXPERIMENT DESIGN, B. Am. Meteorol. Soc., 93, 485-498, doi:10.1175/bams-d-11-00094.1, 2012.

Tegen, I., Harrison, S. P., Kohfeld, K., Prentice, I. C., Coe, M., and Heimann, M.: Impact of vegetation and preferential source areas on global dust aerosol: Results from a model study, J. Geophys. Res.-Atmos., 107, 4576, 4576, doi:10.1029/2001jd000963, 2002.

Textor, C., Schulz, M., Guibert, S., Kinne, S., Balkanski, Y., Bauer, S., Berntsen, T., Berglen, T., Boucher, O., Chin, M., Dentener, F., Diehl, T., Easter, R., Feichter, H., Fillmore, D., Ghan, S., Ginoux, P., Gong, S., Grini, A., Hendricks, J., Horowitz, L., Huang, P., Isaksen, I., Iversen, I., Kloster, S., Koch, D., Kirkevåg, A., Kristjansson, J. E., Krol, M., Lauer, A., Lamarque, J. F., Liu, X., Montanaro, V., Myhre, G., Penner, J., Pitari, G., Reddy, S., Seland, Ø., Stier, P., Takemura, T., and Tie, X.: Analysis and quantifica- 
tion of the diversities of aerosol life cycles within AeroCom, Atmos. Chem. Phys., 6, 1777-1813, doi:10.5194/acp-6-1777-2006, 2006.

Thornton, D. C., Bandy, A. R., Blomquist, B. W., Driedger, A. R., and Wade, T. P.: Sulfur dioxide distribution over the Pacific Ocean 1991-1996, J. Geophys. Res.-Atmos., 104, 5845-5854, doi:10.1029/1998JD100048, 1999.

Trivitayanurak, W., Adams, P. J., Spracklen, D. V., and Carslaw, K. S.: Tropospheric aerosol microphysics simulation with assimilated meteorology: model description and intermodel comparison, Atmos. Chem. Phys., 8, 3149-3168, doi:10.5194/acp-83149-2008, 2008.

Tsigaridis, K. and Kanakidou, M.: Secondary organic aerosol importance in the future atmosphere, Atmos. Environ., 41, 46824692, doi:10.1016/j.atmosenv.2007.03.045, 2007.

Tsigaridis, K., Koch, D., and Menon, S.: Uncertainties and importance of sea spray composition on aerosol direct and indirect effects, J. Geophys. Res.-Atmos., 118, 220-235, doi:10.1029/2012jd018165, 2013.

Tzivion, S., Feingold, G., and Levin, Z.: An Efficient Numerical Solution to the Stochastic Collection Equation, J. Atmos. Sci., 44, 3139-3149, 1987.

Tzivion, S., Feingold, G., and Levin, Z.: THE EVOLUTION OF RAINDROP SPECTRA .2. COLLISIONAL COLLECTION BREAKUP AND EVAPORATION IN A RAINSHAFT, J. Atmos. Sci., 46, 3312-3327, doi:10.1175/15200469(1989)046<3312:teorsp>2.0.co;2, 1989.

Tzivion, S., Reisin, T. G., and Levin, Z.: A new formulation of the spectral multi-moment method for calculating the kinetic collection equation: More accuracy with fewer bins, J. Comput. Phys., 171, 418-422, doi:10.1006/jcph.2001.6776, 2001.

Uematsu, M., Duce, R. A., and Prospero, J. M.: DEPOSITION OF ATMOSPHERIC MINERAL PARTICLES IN THE NORTH PACIFIC-OCEAN, J. Atmos. Chem., 3, 123-138, doi:10.1007/bf00049372, 1985.

van der Werf, G. R., Randerson, J. T., Giglio, L., Collatz, G. J., Mu, M., Kasibhatla, P. S., Morton, D. C., DeFries, R. S., Jin, Y., and van Leeuwen, T. T.: Global fire emissions and the contribution of deforestation, savanna, forest, agricultural, and peat fires (19972009), Atmos. Chem. Phys., 10, 11707-11735, doi:10.5194/acp10-11707-2010, 2010.
Vehkamaki, H., Kulmala, M., Napari, I., Lehtinen, K. E. J., Timmreck, C., Noppel, M., and Laaksonen, A.: An improved parameterization for sulfuric acid-water nucleation rates for tropospheric and stratospheric conditions, J. Geophys. Res.-Atmos., 107, 4622, doi:10.1029/2002JD002184, 2002.

Vignati, E., Wilson, J., and Stier, P.: M7: An efficient sizeresolved aerosol microphysics module for large-scale aerosol transport models, J. Geophys. Res.-Atmos., 109, D22202, doi:10.1029/2003jd004485, 2004.

Wang, M., Ghan, S., Ovchinnikov, M., Liu, X., Easter, R., Kassianov, E., Qian, Y., and Morrison, H.: Aerosol indirect effects in a multi-scale aerosol-climate model PNNL-MMF, Atmos. Chem. Phys., 11, 5431-5455, doi:10.5194/acp-11-5431-2011, 2011.

Wanninkhof, R.: Relationship between wind speed and gas exchange over the ocean, J. Geophys. Res.-Oceans, 97, 7373-7382, doi:10.1029/92jc00188, 1992.

Westervelt, D. M., Pierce, J. R., Riipinen, I., Trivitayanurak, W., Hamed, A., Kulmala, M., Laaksonen, A., Decesari, S., and Adams, P. J.: Formation and growth of nucleated particles into cloud condensation nuclei: model-measurement comparison, Atmos. Chem. Phys., 13, 7645-7663, doi:10.5194/acp-13-76452013, 2013.

Young, P. J., Archibald, A. T., Bowman, K. W., Lamarque, J.-F., Naik, V., Stevenson, D. S., Tilmes, S., Voulgarakis, A., Wild, O., Bergmann, D., Cameron-Smith, P., Cionni, I., Collins, W. J., Dalsøren, S. B., Doherty, R. M., Eyring, V., Faluvegi, G., Horowitz, L. W., Josse, B., Lee, Y. H., MacKenzie, I. A., Nagashima, T., Plummer, D. A., Righi, M., Rumbold, S. T., Skeie, R. B., Shindell, D. T., Strode, S. A., Sudo, K., Szopa, S., and Zeng, G.: Preindustrial to end 21 st century projections of tropospheric ozone from the Atmospheric Chemistry and Climate Model Intercomparison Project (ACCMIP), Atmos. Chem. Phys., 13, 2063 2090, doi:10.5194/acp-13-2063-2013, 2013.

Yu, F. and Luo, G.: Simulation of particle size distribution with a global aerosol model: contribution of nucleation to aerosol and CCN number concentrations, Atmos. Chem. Phys., 9, 76917710, doi:10.5194/acp-9-7691-2009, 2009.

Zhang, Y., Seigneur, C., Seinfeld, J. H., Jacobson, M. Z., and Binkowski, F. S.: Simulation of aerosol dynamics: A comparative review of algorithms used in air quality models, Aerosol Sci. Technol., 31, 487-514, 1999. 